\title{
O PENSAMENTO AMBIENTAL SISTÊMICO: UMA ANÁLISE DA COMUNICAÇÃO CIENTÍFICA DA ESALQ/USP
}

\section{RENATA COELHO SARTORI}

Dissertação apresentada à Escola Superior de Agricultura "Luiz de Queiroz", Universidade de São Paulo, para obtenção do título de Mestre em Ecologia de Agroecossistemas.

P I R A C I C A B A

Estado de São Paulo - Brasil

Março - 2005 


\title{
O PENSAMENTO AMBIENTAL SISTÊMICO: UMA ANÁLISE DA COMUNICAÇÃO CIENTÍFICA DA ESALQ/USP
}

\section{RENATA COELHO SARTORI}

Bacharel em Comunicação Social

Orientador: Prof. Dr. ANTÔNIO RIBEIRO DE ALMEIDA JÚNIOR

\begin{abstract}
Dissertação apresentada à Escola Superior de Agricultura "Luiz de Queiroz", Universidade de São Paulo, para obtenção do título de Mestre em Ecologia de Agroecossistemas.
\end{abstract}

P I R A C I C A B A

Estado de São Paulo - Brasil

Março - 2005 
Dados I nt ernaci onai s de Cat al ogação na Publi cação ( $C l P$ ) DI VI SÃO DE BI BLI OTECA E DOCUMENTAÇÃO - ESALQI USP

Sartori, Renata Coelho

O pensamento ambiental sistêmico: uma análise da comunicação científica da

ESALQ/USP / Renata Coelho Sartori. - - Piracicaba, 2005.

109 p. : il.

Dissertação (mestrado) - - Escola Superior de Agricultura Luiz de Queiroz, 2005.

Bibliografia.

1. Comunicação científica 2. ESALQ 3. Pensamento ambiental 4. Pesquisa agrícola I. Título

CDD 630.72 
À minha família,

Renato, Bernadette e Renan, essência da minha vida, o amor, a paciência $e$ compreensão, os sacrificios partilhados, mas sobretudo a inesgotável fonte de estímulo para o meu aprimoramento, sem o qual talvez este trabalho não teria sido finalizado.

\section{Ao Eduardo,}

o seu amor, sua paciência, companheirismo, incentivo, amizade e auxífio constantes.

Dedico-lhes com amor este trabalho. 


\section{AGRADECIMENTOS}

"O que queres que os homens façam por ti, faze igualmente por eles" (Jesus Cristo).

A Deus, e sua presença constante em minha vida, dando-me força através da sua graça e misericórdia para enfrentar as dificuldades;

Ao Prof.Dr. Antônio Ribeiro de Almeida Júnior, orientador deste trabalho, a oportunidade e confiança depositada em mim, meu sincero agradecimento. Seus valiosos ensinamentos e acuradas críticas que contribuíram para a realização $e$ aprimoramento da presente pesquisa;

Aे Profa.Dra. Silvia M. Guerra Molina a compreensão e disposição nos momentos de dúvidas e suas palavras de carinho e apoio;

Às Prof ${ }^{a}$.Dra. Maria Elisa E.P. Garavello e Arlete Assumpção Monteiro, a solicitude com que participaram como examinadoras, na prova de qualificação e as sugestões apresentadas;

À Profa.Dra. Dinah Ap.Aguiar Población, a oportunidade de desfrutar de seus conhecimentos e amizade;

Aos Professores Oriowaldo Queda e Toshio Nojimoto, o apoio e a gentileza pela doação de material; 
Aे todos os professores do PPGI Ecologia de Agroecossistemas, os ensinamentos transmitidos;

À funcionária da secretaria do PPGI, Regina Freitas, a presteza e solicitude com que sempre me atenderam;

Às bibliotecárias do campus USP/Piracicaba, Silvia e Eliana;

Ao meu irmão Antonio Fernando, o estímulo em mais esta fase da minha vida;

Às amigas Adriana, Ana Margarida, Leila, Lúcia Elvira, Maria do Carmo...a amizade, o apoio e incentivo;

À Ana Claudia Pereira de Oliveira, Julia Salvador Martins e Márcia Regina da Silva, o carinho e a amizade, por dividirmos momentos de alegria, de angústia e dúvidas; enfim por todos os caminhos que juntas percorremos;

À tia Elza Coelho, agradeço o apoio e carinho das suas preciosas oraçôes;

À Coordenação de Aperfeiçoamento de Pessoal de Nivel Superior (CAPES), o apoio financeiro;

Enfim, a todos aqueles que de alguma forma contribuíram para a realização deste trabalho. 


\section{A CÂMARA PARADIGMÁTICA DE PASÁRGADA 2}

"Convencida pelos argumentos de alguns filósofos, cientistas e humanistas de que o paradigma da modernidade estava a entrar em uma crise final e que a competição de um paradigma emergente estava de fato em aberta, a comunidade educacional de Pasárgada 2 verificou que as suas instituições educacionais não davam qualquer sinal de que essa crise existia e suprimiam de vários modos, uns mais sutis que outros, a idéia de que um novo paradigma poderia estar no horizonte e de que era do interesse dos cidadãos-estudantes conhecê-lo. A simples hipótese de uma alternativa radical deixava-os nervosos e escondiam os nervos silenciando ou ridicularizando os que admitiam tal hipótese. Os nervos e a sua ocultação eram tanto maiores quanto maiores eram as responsabilidades profissionais das instituições. Perante isto, a comunidade de cidadãos-estudantes decidiu formar uma Câmara Paradigmática (...) a única deliberação que tomou foi suspender temporariamente a concessão de diplomas. Como as instituiçães continuam, por agora, a ensinar apenas o paradigma até agora vigente, a Câmara entendeu que, como os diplomas certificam conhecimento apenas desse paradigma, do ponto de vista do paradigma emergente os diplomas correspondem a diplomas de ignorância. Como seria embaraçoso que no futuro os cidadãosestudantes tivessem um diploma de ignorância, e como de pouco Thes servia um diploma que tanto podia ser considerado de conhecimento como de ignorância, a Câmara decidiu suspênde-los temporariamente, admitindo mesmo poder aboli-los mais tarde e para sempre. $\mathcal{A}$ suspensão dos diplomas deu muito mais liberdade aos cidadãos-estudantes e criou um incentivo para as instituições se abrirem à discussão paradigmática. Desprovida do privilégio de certificação, se não se abrirem à discussão, correm o risco de perder os estudantes"(Boaventura de Souza Santos, 2001, p.326-327). 


\section{SUMÁRIO}

LISTA DE TABELAS

LISTA DE ABREVIATURAS DOS PERIÓDICOS CIENTÍFICOS DA

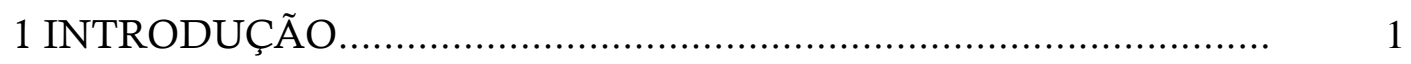

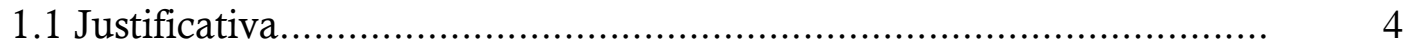

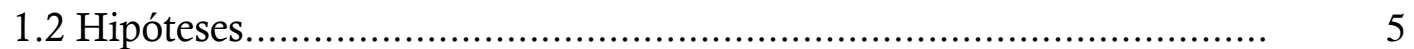

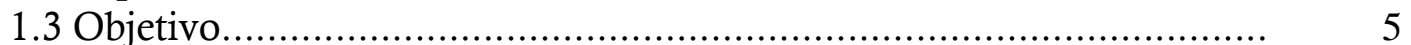

\section{REVISÃO DE LITERATURA}

2.1 A crise ambiental planetária: um desafio ao pensamento científico moderno.

2.1.1 As dimensões da crise ambiental e a urgência da reforma paradigmática do conhecimento.

2.2 A interdisciplinaridade no campo ambiental.................................. 17

2.2.1 A interdisciplinaridade na Teoria Geral dos Sistemas.................... 21

2.3 O paradigma da complexidade: um desafio para a ciência moderna

2.3.1 A importância do pensamento sistêmico para o entendimento da complexidade ambiental.

2.4 A escola superior de agricultura "Luiz de Queiroz": um breve histórico

2.4.1 As polêmicas sobre a incorporação da dimensão ambiental pela ESALQ.

2.4.2 O programa de Pós-Graduação Interunidades "Ecologia de Agroecossistemas" da ESALQ/CENA: um caminho para a interdisciplinaridade no campo ambiental.

2.4.3 A exigência de um novo perfil para o profissional das ciências agrárias frente à problemática ambiental. 
viii

2.5.1 Difusão, disseminação e divulgação científica............................... 40

2.5.2 Conceitos e funções da comunicação científica.............................. 41

2.5.3 A responsabilidade social do pesquisador na divulgação da pesquisa ambiental.

2.5.4 A busca da identificação de um novo paradigma através da comunicação científica................................................................ 46

3 METODOLOGIA................................................................. 48

4 RESULTADOS E DISCUSSÃO............................................... 55

4.1 Das revistas científicas............................................................... $\quad 55$

4.1.1 Análise das características estruturais e administrativas das revistas

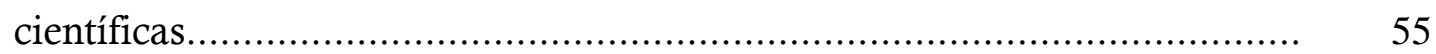

4.1.2 Análise quantitativa das revistas científicas.............................. 63

4.1.2.1 O universo da amostragem............................................... 63

4.1.2.2 Quantificação das revistas científicas "SA" e "SF" quanto à paginação e procedência dos autores (relação autor/artigo e autor/seções temáticas).

4.1.2.3 Quantificação e classificação dos artigos das revistas científicas "SA" e "SF" quanto às abordagens temáticas.........................................

4.2 Quantificação e classificação das teses de livre-docência quanto às abordagens temáticas..................................................................

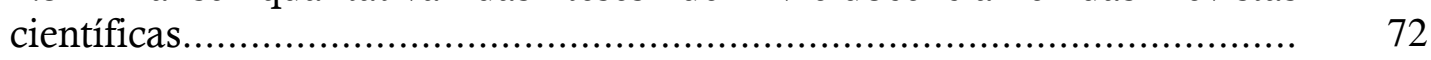

5 CONCLUSÕES E CONSIDERAÇÕES FINAIS............................... 77

REFERÊNCIAS BIBLIOGRÁFICAS.............................................. 80

APÊNDICES................................................................... 91 


\section{LISTA DE TABELAS}

Página

1 Distribuição das revistas selecionadas segundo as características estruturais e administrativas de editoração (1998-2002).

2 Distribuição das revistas selecionadas segundo as características estruturais e administrativas de difusão e visibilidade (19982002)

3 Distribuição dos artigos publicados na revista "SA" segundo as seções temáticas (2000-2002).

4 Classificação das seções temáticas mais e menos abordadas por todos os pesquisadores na revista "SA" (2000-2002).

5 Porcentagem de artigos da revista "SA" avaliados por revisores externos à ESALQ (1997-2001).

6 Levantamento dos fascículos, artigos publicados e artigos analisados da revista "SA" no período de 1998 a 2002.

7 Levantamento dos fascículos, artigos publicados e artigos analisados da revista "SF" no período de 1998 a 2002

8 Percentual das revistas "SA" e "SF" em relação ao conjunto de publicações extraídas de $20 \%$ dos Currículos Lattes dos docentes da ESALQ, no período de 1998 a 2002.

9 Total de páginas analisadas referentes aos artigos publicados na revista "SA" no período de 1998 a 2002

10 Total de páginas analisadas referentes aos artigos publicados na revista "SF" no período de 1998 a 2002. 
11 Identificação da procedência dos autores que publicaram artigos na revista "SA" (1998-2002).

12 Identificação do número total de autores por número de artigos publicados na revista "SA" (1998 - 2002).

13 Identificação das seções temáticas da revista "SA" em que prevaleceram autores procedentes da ESALQ (2000-2002)..............

14 Identificação das seções temáticas da revista "SA" em que prevaleceram autores procedentes de outras instituições (20002002).

15 Resultados comparativos das seções temáticas da revista "SA" escolhidas pelos pesquisadores da ESALQ ou de outras instituições (2000-2002).

16 Identificação da procedência dos autores que publicaram artigos na revista "SF" (1998-2002).

17 Identificação do número total de autores por número de artigos publicados na revista "SF" (1998 - 2002)

18 Classificação e quantificação das categorias quanto aos conteúdos dos artigos das revistas "SA" e "SF" no período de 1998 a 2002

19 Classificação e quantificação das categorias quanto aos conteúdos das teses de livre-docência defendidas na ESALQ, no período de 1998 a 2002.

20 Relação da coleção da Biblioteca disponível na base de dados SciELO e classificação da revista "SA" quanto ao número de exemplares indexados

21 Volumes disponíveis na base de dados SciELO no período de 1996 a 2002 . 
22 Acesso aos números da revista "SA" realizado no período de 2001 a 2002 .

23 Classificação dos fascículos de 2001 em relação aos fascículos mais visitados da revista "SA", medida pelo número de acessos aos resumos e aos artigos em HTML e em PDF, (de janeiro a dezembro de 2001).

24 Classificação dos fascículos de 2002 em relação aos fascículos mais visitados da revista "SA", medida pelo número de acessos aos resumos e aos artigos em HTML e em PDF, (de janeiro a 09 de novembro de 2002)

25 Relação de revistas citadas pela revista "SA" no ano de 2001

26 Relação de revistas citadas pela revista "SA" no ano de 2002

27 Relação de revistas que citaram os artigos da revista "SA" no ano de 2001

28 Relação de revistas que citaram os artigos da revista "SA" no ano de 2002.

29 Totalização das principais revistas que citaram a revista "SA" no período de 2001 a 2002

30 Classificação dos artigos publicados no Volume 58 da revista "SA" no ano de 2001: levantamento do tipo de formato disponível e idioma.

31 Classificação dos artigos publicados no Volume 59 da revista "SA" no ano de 2002: levantamento do tipo de formato disponível e idioma.... 


\section{LISTA DE ABREVIATURAS}

ABEC

ABNT

AGRIS

AGROBASE

BIREME

$\mathrm{CABi}$

CAPES

CENA

CCC

$\mathrm{CNPq}$

$\mathrm{CO}_{2}$

ECA

EMBRAPA

ESALQ

FAPESP

HTML

IBGE

INIS

IPEF
Associação Brasileira de Editores Científicos

Associação Brasileira de Normas Técnicas

Agrarian Information System

Base Bibliográfica da Agricultura Brasileira

Centro Latino-Americano e do Caribe de Informação em Ciências da Saúde

Chemical Abstracts International

Coordenadoria de Assistência à Pesquisa e Ensino Superior

Centro de Energia Nuclear na Agricultura

Current Contents Conect

Conselho Nacional de Desenvolvimento Científico e Tecnológico

Dióxido de carbono ou gás carbônico

Escola de Comunicação e Artes

Empresa Brasileira de Pesquisa Agropecuária

Escola Superior de Agricultura "Luiz de Queiroz"

Fundação de Amparo à Pesquisa do Estado de São Paulo

Hiper Text Markup Language

Instituto Brasileiro de Geografia e Estatística

International Nuclear Information System

Instituto de Pesquisas e Estudos Florestais 
ISI

ISSN

ONU

PDF

SA

SciElO

$\mathrm{SF}$

TGS

USA

USP
Institute for Scientific Information

International Standart Serial Number

Organização das Nações Unidas

Portable Document Format

Scientia Agricola

Scientific Eletronic Library Online

Scientia Forestalis

Teoria Geral dos Sistemas

United States of America

Universidade de São Paulo 


\title{
LISTA DE ABREVIATURAS DOS PERIÓDICOS CIENTÍFICOS DA SciELO
}

\author{
BRAZ.J.BIOL. Brazilian Journal of Biology \\ BRAZ.J.GENET. Brazilian Journal of Genetics \\ BRAZ.J.MICROBIOL. Brazilian Journal of Microbiology \\ BRAZ.J.ZOOTEC. Brazilian Journal of Zootecnia \\ CIENC.RURAL Ciência Rural \\ FITOPATOL.BRAS. Fitopatologia Brasileira \\ HORTIC.BRAS. Horticultura Brasileira \\ J.AGRIC.FOOD CHEM. Journal of Agricultural and Food Chemistry \\ J.ANIM.SCI. Journal of Animal Science \\ J.DAIRY SCI. Journal of Dairy Science \\ J.ECON.ENTOMOL. Journal of Economic Entomologic \\ NEOTROP.ENTOMOL. Neotropical Entomology \\ PESQ.AGROPEC.BRAS. Pesquisa Agropecuária Brasileira \\ REV.BRAS.BOT. Revista Brasileira de Botânica \\ REV.BRAS.CIÊNCIA E Revista Brasileira Ciência e Movimento \\ MOVIMENTO \\ REV.BRAS.FRUT. Revista Brasileira de Fruticultura \\ REV.BRAS.CI.SOLO Revista Brasileira de Ciências do Solo \\ REV.BRAS.SEMENTES Revista Brasileira de Sementes \\ R.SOC.BRAS.ZOOT. Revista da Sociedade Brasileira de Zootecnia \\ SCI.AGRIC. \\ Scientia Agricola (Piracicaba, Brazil) \\ (PIRACICABA, BRAZ.)
}




\title{
O PENSAMENTO AMBIENTAL SISTÊMICO: UMA ANÁLISE DA COMUNICAÇÃO CIENTÍFICA DA ESALQ/USP
}

\author{
Autora: RENATA COELHO SARTORI \\ Orientador: Prof.Dr. ANTÔNIO RIBEIRO DE ALMEIDA JÚNIOR
}

\section{RESUMO}

Durante o século XX sedimentou-se a percepção de que o conhecimento disciplinar fragmentado é incapaz de explicar e resolver a problemática ambiental. A partir disso, surgiu um grande desafio no campo da educação: um amplo e complexo processo de reorientação do conhecimento, das ideologias, dos paradigmas científicos e das práticas de pesquisa. As questões ambientais e sociais abriram o caminho para o pensamento sistêmico e também para métodos interdisciplinares de pesquisa, capazes de articular diferentes disciplinas com o intuito de compreender as múltiplas relações, causalidades e interdependências entre os processos naturais e sociais. É nessa perspectiva que se inscreve um novo paradigma concebido por Edgar Morin e denominado de pensamento complexo, que se origina no pensamento sistêmico. Este estudo analisou as publicações científicas "Scientia Agricola" (SA) e "Scientia Forestalis” (SF), bem como todas as teses de livre-docência desenvolvidas pela ESALQ/USP, no período de 1998 a 2002. A partir desse conjunto, utilizou-se para análise uma amostragem correspondente a 20\%, sendo 136 artigos científicos da "SA"e “SF” e todas as 40 teses de livre-docência. Buscou-se conhecer as abordagens adotadas, as quais foram categorizadas sob dois aspectos: $1^{\circ}$ ) Caráter Interdisciplinar e $2^{\circ}$ ) Se 
estavam inseridas no novo paradigma (pensamento sistêmico, segundo Morin). Também foram analisadas as características estruturais e administrativas dos periódicos. Somente 6 artigos (4,4\% da amostra) empregaram o pensamento sistêmico. Estes artigos também foram considerados interdisciplinares, sendo 1 artigo publicado na revista "SA" e 5 na revista “SF”. Apenas duas teses de livre-docência (5\% do total) empregaram o pensamento sistêmico. Os resultados obtidos no estudo permitem concluir que os periódicos científicos “SA" e "SF” possuem prestígio e estão consolidados por suas periodicidades ininterruptas, corpos editoriais compostos por renomados profissionais. Estas publicações são importantes veículos de disseminação do conhecimento científico agrário e florestal. Entretanto, seguem linhas editoriais que não apresentam uma análise ambiental sistêmica ou complexa. Em geral, as pesquisas publicadas por ambos periódicos científicos e as teses de livre-docência, não possuem uma abordagem ambiental com bases conceituais integradas e interdisciplinares. Há uma forte tendência à fragmentação cartesiana e à separação entre o humano e o natural. Na produção científica da ESALQ analisada, a interdisciplinaridade e a idéia de complexidade são temas ainda ausentes e a pesquisa científica tem obstáculos epistemológicos, metodológicos e institucionais por enfrentar.

Palavras-Chave: pensamento ambiental, comunicação científica, ESALQ. 


\title{
THE SYSTEMIC ENVIRONMENTAL THOUGHT: AN ANALYZE OF SCIENTIFIC COMMUNICATION FROM ESALQ/USP
}

\author{
Author: RENATA COELHO SARTORI \\ Adviser: ANTÔNIO RIBEIRO DE ALMEIDA JÚNIOR
}

\section{SUMMARY}

During the 20th Century, the perception that the fragmented disciplinary knowledge has been unable to explain and solve environmental problems consolidated. Since then, a major challenge has raised in the educational field: a wide and complex reorientation process of knowledge, ideologies, scientific paradigms and research practices. The environmental and social questions opened a path for systemic thought and interdisciplinary research methods, capable of linking different disciplines in order to understand multiple relations, causalities and interdependence among natural and social processes. Created by Edgar Morin from the systemic thought, the complex thought is within this context. This study analyzed the following scientific publication: "Scientia Agricola" (SA) and "Scientia Forestalis" (SF), as well as all post-doctoral theses developed by the teaching staff at ESALQ/USP from 1998 to 2002. Considering this collection, a 20\% sample has been analyzed, which means 136 articles from "SA" and "SF" and all 40 theses. It was tried to grasp the adopted approaches which were classified according to two features: 1) interdisciplinary content and 2) if they were 
within a new scientific paradigm (systemic thought, according to Morin). The journal administrative and structural features were also analyzed. Only six articles (4.4\% of the sample) used the systemic thought. Those articles were also considered interdisciplinary. One of them was from "SA" and the remaining from "SF". Only two theses (5\% of total) used some systemic thought. The results from this study allowed us to conclude that the "SA" and "SF" scientific journals have been considered prestigious and consolidated because of their long and uninterrupted publication, editorial board composed by widely-known professionals. These publications are an important mean of dissemination of agrarian and forestry scientific knowledge. Nevertheless, they follow editorial approaches that do not present a systemic or complex environmental analysis or perspective. In general, the research published by both scientific journals and teaching staff theses do not present interdisciplinary and integrated approaches. There is a strong tendency towards the Cartesian fragmentation and a split between human and natural dimensions. In the ESALQ scientific production, the interdisciplinary and complexity ideas have been still absent from research themes. In order to incorporate them, the scientific research has still to surpass institutional, methodological and epistemic obstacles.

Keywords: environmental thought, scientific communication, ESALQ. 


\title{
1 INTRODUÇÃO
}

\begin{abstract}
“Assistimos à emergência de uma ciência que não está mais limitada a situações simplificadoras, idealizadas, mas que nos coloca diante da complexidade do mundo real, de uma ciência que permite à criatividade humana viver como expressão singular de um laço fundamental de todos os niveis da natureza" (Ilya Prigogine, 1996).
\end{abstract}

Durante o século $X X$ sedimentou-se a percepção de que o conhecimento disciplinar fragmentado é incapaz de explicar e resolver a complexidade da problemática ambiental. A partir disso, surge um grande desafio no campo da educação: um amplo e complexo processo de reorientação do conhecimento, das ideologias, dos paradigmas científicos e das práticas de pesquisa.

O conhecimento científico necessário para compreender a dinâmica dos processos socioambientais, situa-se além do conhecimento disciplinar. Como destacado por Leff (2202a, p.168), o saber ambiental não constitui um campo discursivo homogêneo para ser assimilado pelas diferentes disciplinas científicas. O saber ambiental emerge de uma razão crítica, configurando-se em contextos ecológicos, sociais e culturais. Segundo o autor, este saber se estende, além do campo de articulação das ciências, para o terreno dos valores éticos, dos conhecimentos práticos e dos saberes tradicionais.

Dessa forma, para entender a problemática ambiental, torna-se necessária uma visão dinâmica e holística do ambiente que atue através de métodos interdisciplinares de pesquisa, e na abertura para o caminho do pensamento da complexidade. Os problemas da complexa rede de relações socioambientais necessitam de uma abordagem sistêmica que não está inserida na ciência clássica, mas sim, em um novo paradigma ${ }^{1}$, como afirma Morin:

\footnotetext{
$\overline{{ }^{1} \text { Na concepção de Kuhn }}$ (1990, p.219) "um paradigma é aquilo que os membros de uma comunidade partilham e, inversamente, uma comunidade científica consiste em homens que partilham um paradigma”.
} 


\begin{abstract}
"Chamo paradigma de complexidade ao conjunto dos princípios de inteligibilidade que, ligados uns aos outros, poderiam determinar as condições de uma visão complexa do universo (físico, biológico, antropossocial) (...) O paradigma da complexidade não 'produz' nem 'determina' $a$ inteligibilidade. Pode somente incitar a estratégia/inteligência do sujeito pesquisador a considerar a complexidade da questão estudada. Incita a distinguir e fazer comunicar em vez de isolar e de separar (...) Incita a dar conta dos caracteres multidimensionais de toda realidade estudada” (Morin, 1996, p.330-334).
\end{abstract}

Segundo Kuhn (2000, p.122), a transição de um paradigma em crise para um novo, resulta em uma revolução científica.

Para Kuhn (2000, p.117-199), um novo paradigma emerge antes que uma crise esteja "bem desenvolvida ou tenha sido explicitamente reconhecida" e para que tenha êxito, é necessário que "conquiste alguns adeptos iniciais, que o desenvolverão até o ponto em que argumentos objetivos possam ser produzidos e multiplicados".

Kuhn (2000, p.45) afirma que, em geral, os cientistas trabalham no contexto da ciência normal, ou seja, não estão constantemente procurando inventar novas teorias, pois "a ciência normal não tem como objetivo trazer à tona novas espécies de fenômenos; na verdade, aqueles que não se ajustam aos limites do paradigma freqüentemente nem são vistos”. Assim funciona até que haja uma ruptura gerada a partir de perguntas não respondidas nos limites do paradigma anterior, que demanda modificações profundas em direção à construção de um novo paradigma. A adoção de novos conceitos, diferentes enfoques e teorias originais serão decorrentes da implementação do eventual paradigma revolucionário.

Para Gaston Bachelard, podemos empregar o termo ruptura epistemológica "as crises de crescimento do pensamento implicam uma reorganização total do sistema do saber" (Bachelard, 1999, p.20). No contexto teórico em que estamos abordando a problemática ambiental, ou seja, da transição paradigmática proposta por Morin, é primordial que essa seja tratada na pesquisa de maneira complexa e interdisciplinar, buscando conhecimentos para padrões mais sustentáveis de desenvolvimento. Para tanto, como parte integrante desse processo, a universidade tem 
uma função significativa na produção e divulgação desses conhecimentos e o mesmo ocorre com as revistas e outras formas de comunicação científica.

É importante ressaltar que os periódicos científicos podem definir e legitimar novas disciplinas e campos dos saberes (Miranda, 1996, p.376) e também que as mudanças epistemológicas não só dependem do questionamento externo às ciências, mas das próprias estruturas do conhecimento em cada campo do saber, que as tornam mais flexíveis ou rígidas para incorporar e unificar o saber ambiental (Leff, 2002a, p.141). Tais colocações aproximam-se bastante da abordagem aqui analisada.

Portanto, a finalidade deste estudo é analisar a pesquisa da Escola Superior de Agricultura "Luiz de Queiroz", da Universidade de São Paulo (ESALQ/USP) - Campus de Piracicaba/SP, presente nas revistas Scientia Agricola,

Scientia Forestalis e todas as teses de livre-docência, procurando revelar a presença ou não do novo paradigma científico, caracterizado pela abordagem das questões ambientais em sua complexidade. Essa perspectiva, de buscar identificar a presença ou ausência de determinado paradigma através da análise das pesquisas publicadas em periódicos científicos e teses, é pouco conhecida e sistematizada à luz do campo das pesquisas sobre comunicação científica.

Gostaríamos de destacar que não pretendemos fazer uma crítica pessoal nem uma avaliação da produção científica dos pesquisadores da Instituição, mas analisar se a temática ambiental é abordada nas revistas e nas teses utilizando-se o Paradigma da Complexidade (pensamento sistêmico ou complexo²), proposto por Edgar Morin.

Esperamos, contudo, que este trabalho possa servir de reflexão sobre uma nova abordagem das pesquisas, sob este novo paradigma, na comunidade acadêmica em geral e em particular na ESALQ. Embora modesto, é relevante e recente

\footnotetext{
${ }^{2}$ Segundo Morin (2001, p.151) os dois termos pensamento sistêmico e pensamento complexo são sinônimos. Neste trabalho, optamos por utilizar o termo pensamento sistêmico e procuramos vincular este à temática ambiental. Na ciência do século XX, a perspectiva holística tornou-se conhecida como sistêmica, e a maneira de pensar que ela implica passou a ser conhecida como pensamento sistêmico. Os pioneiros deste pensamento foram os biólogos, que enfatizavam a concepção dos organismos vivos como totalidades integradas. Bertalanffy é reconhecido como o autor da primeira formulação de um arcabouço teórico abrangente com os princípios de organização dos sistemas vivos.

Na mudança do pensamento mecanicista para o pensamento sistêmico, a relação entre as partes e o todo foi invertida. No primeiro é considerado que em todo o sistema complexo o comportamento do todo pode ser analisado inteiramente a partir das propriedades de suas partes. No segundo mostra que os sistemas vivos não podem ser compreendidos por meio de análise. As propriedades das partes não são propriedades intrínsecas, mas podem ser entendidas dentro de um contexto do todo mais amplo.
} 
porque partiu da análise de cinco anos de publicações desenvolvidas por pesquisadores da ESALQ, diante de mais de cem anos de existência da Instituição.

Também não pretendemos afirmar que toda a pesquisa da ESALQ encontra-se nas mesmas condições daquelas que aparecem publicadas nas revistas “Scientia Agricola” e “Scientia Forestalis” e nas teses de livre-docência. Ainda que possamos formular esta hipótese, ela deverá ser testada em outros trabalhos de investigação.

\subsection{Justiticativa}

O presente trabalho justifica-se a partir da constatação de que o conhecimento científico moderno tem apresentado sinais - como já mencionamos, sobre a complexidade da problemática ambiental - de que está atravessando uma grande crise, o que vem a propiciar uma profunda reflexão epistemológica sobre o conhecimento científico. Os problemas emergentes do mundo moderno caracterizam-se por uma crescente complexidade, a questão ambiental, por exemplo, propõe a necessidade de um pensamento holístico (sistêmico), capaz de perceber as inter-relações entre os diferentes processos que incidem e caracterizam seu campo problemático.

Se as questões ambientais continuarem sendo abordadas de modo fragmentado e isoladas de um contexto sistêmico, a universidade tende a perder a capacidade de pensar os problemas concretos e emergentes, afastando-se assim, cada vez mais, da realidade que está em processo constante de mudanças. Isto tem implicações na própria sobrevivência da universidade, comprometendo sua função de servir à sociedade.

Essa discussão mostra a caracterização da crise do paradigma dominante e a emergência de um novo paradigma que venha a substituí-lo. Pretende-se caracterizar essa crise e a emergência de um novo paradigma a partir da leitura crítica de vários autores, indicados nas Referências Bibliográfica, e principalmente das contribuições implícitas nas obras de Edgar Morin. Também ressaltamos que embora a extensa literatura sobre as questões ambientais tenha crescido consideravelmente durante os últimos anos, ainda há poucas publicações abordando a temática proposta por esta pesquisa, que utiliza a comunicação científica como relevante instrumento para 
análise da temática ambiental, propiciando a identificação do tipo de paradigma utilizado pelos pesquisadores de uma determinada comunidade científica.

A adoção de Edgar Morin como principal autor para a definição do novo paradigma deve-se ao fato de que ele pensa o sistêmico de uma maneira que já se tornou clássica. Seu pensamento não está tentando superar o pensamento sistêmico, como em vários autores contemporâneos. Por isso, consideramos que Morin pode ser tratado como um autor que estabelece critérios bastante inclusivos em sua definição de novo paradigma. Pensamos que isso é importante, pois não esperamos que as publicações e as teses de livre-docência da Instituição sejam analisadas por um pensamento de vanguarda, mas por pensamento moderado e fundado em avanços consolidados.

\subsection{Hipóteses}

As nossas hipóteses assumem que: a) os periódicos científicos predominantemente seguem linhas temáticas nas quais os artigos não apresentam uma análise ambiental dentro de uma visão sistêmica ou complexa, o que desafia essas publicações da ESALQ em seu campo de conhecimento, de superar o reducionismo da ciência clássica, e b) as pesquisas publicadas nos periódicos científicos e nas teses de livre-docência da ESALQ, consideradas como modelos de pesquisa da Instituição, não contemplam uma dimensão ambiental com pressupostos conceituais integrados e interdisciplinares, tendendo à fragmentação. Essa dissociação entre homem/natureza resulta na dificuldade em combinar aspectos ecológicos, sócio-econômicos, políticos e culturais. Assim, presumimos que sejam pouco abordados assuntos envolvendo as questões sociais e culturais relativas à problemática ambiental.

\subsection{OBJETIVO}

O objetivo deste trabalho é o de analisar as publicações “Scientia Agricola" e "Scientia Forestalis" e as teses de livre-docência desenvolvidas na ESALQ, procurando verificar se estão ou não inseridas no novo paradigma científico caracterizado pela abordagem das questões ambientais em sua complexidade e pelo contexto interdisciplinar, tendo como interface suas dimensões sociais e naturais. 


\section{REVISÃO DE LITERATURA}

\subsection{A crise ambiental planetária: um desafio ao pensamento científico herdado}

"Negar totalmente a crise ambiental, seria trair não apenas nosso melhor julgamento, mas também a capacidade essencial da percepção humana" (David Hutchison, 2000).

À primeira vista, as considerações a seguir, acerca da crise ambiental e sua extensão, parecem fugir à temática central deste estudo que propõe uma análise das publicações e das teses de livre-docência desenvolvidas na ESALQ, procurando verificar se estão ou não inseridas no novo paradigma científico caracterizado pela abordagem das questões ambientais em sua complexidade. No entanto, tais observações são fundamentais às nossas reflexões, pois discutir a crise, seus complexos problemas ambientais e reconhecer que a solução destes, também implica na reflexão sobre mudanças profundas na organização do conhecimento, de um novo paradigma que inclui a noção de totalidade, fundamental para a compreensão e para a ação equilibrada no ambiente, que é inteiro e não fragmentado. Daí nota-se que a problemática ambiental traz uma contribuição importante para repensar o ensino superior, no nosso caso, a pesquisa acadêmica que deve ser interdisciplinar, desempenhando também o papel de não somente advertir, mas também conceber soluções para um futuro sustentável.

Leff considera evidente a relação entre crise, problemática ambiental e problemas do conhecimento:

"A crise ambiental é a primeira crise do mundo real produzida pelo desconhecimento do conhecimento; da concepção do mundo e do domínio da natureza (...). Os problemas ambientais são fundamentalmente problemas de conhecimento (...). A crise ambiental constitui um chamado à reconstrução social do mundo: apreender a complexidade ambiental” (Leff, 2002a, p.207-218). 
Para Santos (2001b, p.282-283), a degradação ambiental é um dos problemas fundamentais, além da explosão demográfica e da globalização da economia. O autor define como problemas fundamentais aqueles que estão “na raiz das nossas práticas e nossas instituições, modos profundamente arraigados de estruturação e de ações sociais, repercutindo com intensidade variável nos mais diversos setores da vida social”.

A partir desses problemas, Santos aponta e critica os limites do conhecimento científico da ciência moderna:

"A profundidade e a amplitude desse tipo de problema suscitam soluções também profundas e amplas e aí reside a dificuldade específica deste tipo de problema (...) o tipo de conhecimento científico que apresenta soluções de curto prazo, estreitas no âmbito e superficiais na espessura (...) deslegitimou à partida a idéia de alternativas globais (...). É notório que a ciência moderna em geral e as ciências sociais em particular atravessam hoje uma profunda crise de confiança epistemológica” (Santos, 2001b, p.283).

Dessa forma, se os rumos sociais não sofrerem redirecionamentos, a crise ambiental em um futuro não muito distante, irá atingir catástrofes ambientais, em que grandes contingentes da população mundial virão a ficar sem acesso a água potável, a alimentos saudáveis, solos agriculturáveis, atmosfera com qualidade etc. Assim, há necessidade de estudos que busquem alternativas para questões ambientais, não apenas sob seus aspectos ecológicos, mas também éticos, políticos, sociais, econômicos, científicos, tecnológicos e culturais, ou seja, sob uma visão integrada do ambiente desenvolvida por um enfoque que dê conta das relações existentes.

Além de Santos (2001b), o caráter planetário dessa crise também é reconhecido por outros autores, como podemos perceber no texto a seguir:

"Na medida em que a maior parte das questões ecológicas conseqüentes é tão obviamente global, as formas de intervenção para minimizar os riscos ambientais terão necessariamente uma base planetária. Um sistema geral de cuidado planetário pode ser criado, tendo como meta a preservação do bem-estar ecológico do mundo como um todo" (Giddens, 1991, p.169).

Assim como Giddens, Capra (1982, p.14) compartilha do mesmo 
pensamento, afirmando que para descrevermos esse mundo, é necessário tomar uma perspectiva ecológica, diferentemente da visão de mundo mecanicista de Descartes e Newton, ou seja: "vivemos num mundo globalmente interligado, no qual os fenômenos biológicos, psicológicos, sociais e ambientais são todos interdependentes”.

A esse respeito, Morin corrobora com o pensamento de Capra em entrevista dada a Sereza (2002, p.D6):

\begin{abstract}
“(...) estamos habituados a viver com conhecimentos separados, com especialistas em todos os assuntos falando de um modo fragmentado. Isso torna muito difícil abordar os problemas de forma global, os problemas fundamentais da humanidade”.
\end{abstract}

Morin prega a construção de uma nova forma de pensar, permitindo a religação dos saberes e a abordagem dos problemas de uma forma global, resultando em um novo paradigma.

\title{
2.1.1 As dimensões da crise ambiental e a urgência da reforma paradigmática do conhecimento
}

Durante o século XX, a demografia, o desenvolvimento, a economia, a ecologia tornaram-se problemas que dizem respeito a todas as nações, ou seja, ao planeta como um todo. No início do século XXI alguns desses problemas herdados do século XX continuam muito evidentes. Populações vêm dilapidando seus recursos como peixes, florestas, água e terra cultivável num ritmo rápido e progressivo. A seguir, apresentaremos resumidamente alguns aspectos dessa problemática ambiental.

Segundo estudo intitulado "Levantando o Consumo Ambiental Excessivo da Economia Humana”, realizado por uma equipe internacional de pesquisadores, o consumo de recursos naturais pelos seres humanos desde 1961 quase duplicou e hoje supera em 20\% a capacidade de reposição da Terra (Polakovic, 2002, p.A15). O cálculo partiu do pressuposto de que se pode explorar até 1,9 hectare por ser humano, mas este número se torna questionável uma vez que o referido estudo não questiona a taxa de natalidade e mortalidade do planeta. Afirma ainda, que qualquer avanço além dessa cota nos deixaria sujeitos a catástrofes meteorológicas, como 
enchentes e secas, e perda da qualidade de vida para as populações futuras.

Leff considera a qualidade de vida um elemento vinculado aos problemas ambientais e sociais:

“(...) a noção de qualidade de vida está necessariamente conectada com a qualidade do ambiente, e a satisfação das necessidades básicas, com a incorporação de um conjunto de normas ambientais para alcançar um desenvolvimento equilibrado e sustentado (...)" (Leff, 2002b, p.149).

Após mais de dez anos da realização da RIO-92, Conferência das Nações Unidas sobre o Desenvolvimento e o Meio Ambiente, ocorrida no Rio de Janeiro, o Brasil adota um padrão de desenvolvimento insustentável do ponto de vista ambiental. A conclusão é da publicação “Indicadores de Desenvolvimento

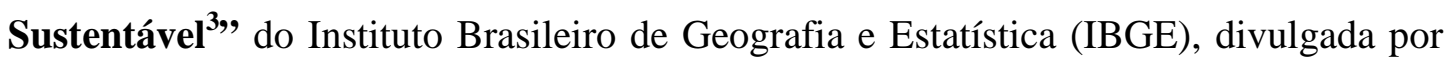
Góis (2002, p.A18). Embora a publicação do IBGE não traga muitos dados novos, ela agrupa em um só documento pela primeira vez no país, 50 indicadores ambientais, sociais e econômicos, segundo a orientação da Comissão para o Desenvolvimento Sustentável da Organização das Nações Unidas (ONU).

O presidente do IBGE, Sérgio Besseman (2002, p.A18) afirma que esta insustentabilidade é global e se traduz no dado da publicação que mostra que a taxa de desmatamento da Amazônia aumentou de 0,37\% em 1991/1992 da área remanescente para 0,48\% em 1998/1999. Além desses indicadores, ele lista: o aumento de 40\% de focos de calor, detectados por satélites, de 104 mil para 145 mil, o que pode indicar aumento de queimadas e incêndios; 59\% do lixo coletado no país não tem destinação adequada; o aumento do uso de fertilizantes e agrotóxicos; a diminuição da qualidade do ar; as precárias condições de saneamento básico; os grandes contingentes humanos sem acesso à água, entre outros problemas.

Em relação à Amazônia, o governo federal anunciou que no período de 2002/2003 houve um crescimento do desmatamento de 2\% em relação a 2001/2002.

\footnotetext{
${ }^{3}$ Segundo Ribeiro (2001,p.112), o relatório Nosso futuro comum produzido em 1988 define desenvolvimento sustentável como "aquele que atende as necessidades do presente sem comprometer a possibilidade de as gerações futuras atenderem as suas próprias necessidades".
} 
Desde 1970, a Amazônia já perdeu 16,3\% da área de floresta, ou seja, cerca de 653 mil km², equivalentes aos territórios da França e de Portugal (Constantino, 2004, p.A16). A contribuição brasileira para o efeito estufa se dá principalmente através do desmatamento; o Brasil passou da confortável posição de $19^{\circ}$ maior emissor de gases-estufa para $5^{\circ}$, perdendo apenas para os EUA, a China, a Rússia e o Japão (Flor, 2004 p.A18).

Denomina-se antropocêntrica essa postura da humanidade diante da natureza, na qual o ser humano se coloca no centro e todas as outras partes que compõem o ambiente estão a seu dispor, sem se aperceber das relações de interdependência entre os elementos existentes no ambiente. Sem um conhecimento integrado do todo, o ser humano não percebe e não respeita as relações de equilíbrio da natureza, agindo sobre o ambiente de modo imprudente, o que acarreta uma desarmonia ambiental.

Há dois aspectos importantes na ciência moderna: $1^{\circ}$ ) o caráter pragmático que o conhecimento adquire, ou seja, o conhecimento cartesiano vê a natureza como um recurso, um meio para se atingir um fim, e $2^{\circ}$ ) o antropocentrismo mencionado anteriormente, isto é, o homem passa a ser visto como o centro do mundo; o sujeito em oposição ao objeto, à natureza. O homem instrumentalizado pelo método científico pode penetrar os mistérios da natureza e, assim, tornar-se senhor e possuidor da natureza.

Segundo Boff, o cuidado para com a Terra representa o global, o cuidado para com o próprio habitat representa o cuidado local. “O ser humano tem os pés no chão (local) e a cabeça aberta para o infinito (global)”. Portanto, o autor afirma que cada pessoa precisa descobrir-se como parte do ecossistema local e da comunidade biótica, seja em seu aspecto de natureza, seja em sua dimensão social. Conclui ressaltando que para cuidar do planeta "precisamos todos passar por uma alfabetização ecológica e rever nossos hábitos de consumo. Importa desenvolver uma ética do cuidado" (Boff , 1999, p.134-135).

A história recente mostra que boas intenções não são suficientes; como 
o ambicioso plano de ação definido pela RIO-92, a Agenda 21, que até agora não foi totalmente implementado. Na verdade, pode ser considerado uma grande lista de boas intenções, entre as quais se destaca o combate à pobreza.

Na Conferência RIO-92, em relação à questão da pobreza, o mundo se comprometeu a reduzir o abismo norte-sul; em 1998, determinou-se que a pobreza deveria ser reduzida pela metade até 2015. Durante a RIO+10, realizada em Johannesburgo no ano de 2002, concluiu-se que um quinto da população mundial vive com menos de US\$ 1 por dia e que a metade da população mundial está malnutrida (Ângelo, 2002, p.A16).

Uma das conseqüências fundamentais da modernidade é a globalização e o desenvolvimento industrial:
"A difusão do industrialismo criou um mundo num sentido mais negativo e ameaçador, um mundo no qual há mudanças ecológicas reais ou potenciais de um tipo daninho que afeta a todos no planeta” (Giddens,1991, p.80-81).

A partir do industrialismo, ou seja, desde 1750, nos primórdios da Revolução Industrial, a concentração atmosférica de carbono aumentou 31\% e mais da metade desse crescimento ocorreu de cinqüenta anos para cá (Teich, 2002, p.83). O que podemos notar é que, além do aquecimento global e do buraco na camada de ozônio, existem danos ambientais palpáveis que afetam a qualidade de vida de todo o planeta.

Todos esses problemas parecem ser faces diferentes de uma mesma crise, movidos pela mesma dinâmica. A maior parte dos intelectuais e especialistas analisa essa realidade de forma restrita e portanto inadequada, uma vez que esses problemas são sistêmicos estando assim ligados intimamente, sendo portanto interdependentes. Logo, não podem ser entendidos no âmbito da metodologia fragmentada, presente na maioria das instituições de ensino e pesquisa.

Segundo Robins ${ }^{4}$ (1997), citado por Woodward (2000, p.20), o

\footnotetext{
${ }^{4}$ ROBINS, K. Global times: what in the world's going on? In: DUGAY, P. (Org.) Production of Culture/Cultures of Production. Londres: Sage/The Open University, lv. 1997.
} 
fenômeno da globalização envolve uma extraordinária transformação:

“(...) as velhas estruturas dos estados e das comunidades nacionais entraram em colapso, cedendo lugar a uma 'transnacionalização' da vida econômica e cultural”.

A globalização envolve uma interação entre os fatores econômicos e culturais, causando mudanças nos padrões de produção e consumo, as quais, por sua vez, produzem idéias novas e globalizadas.

No processo de globalização observam-se mudanças significativas de ordem política, econômica, tecnológica e até mesmo ideológica que ocorrem no mundo. O ponto central dessas mudanças é a integração dos mercados na tão comentada aldeia global, explorado por grandes corporações internacionais. Isso inclui uma intensa revolução tecnológica e uma rápida evolução dos meios de comunicação, o que acaba por provocar uma certa homogeneização cultural entre os países.

Santos (2001b, p.296) afirma que de todos os problemas enfrentados pelo sistema mundial, a degradação ambiental é talvez "o mais intrinsecamente transnacional" e, portanto, aquele que "consoante o modo como for enfrentado, tanto pode redundar num conflito global entre o Norte e o Sul, como pode ser (...) um exercício de solidariedade transnacional”.

Giddens (1991, p.69-70), conceitua a globalização como:

"A intensificação das relações sociais em escala mundial, que ligam localidades distantes de tal maneira que acontecimentos locais são modelados por eventos ocorrendo a muitas milhas de distância e vice-versa".

Santos (1994, p.48) argumenta que a globalização constitui "um estádio supremo de internacionalização, a amplificação em 'sistema-mundo' de todos lugares e de todos os indivíduos, embora em graus diversos”. Para o autor, este conjunto é sistêmico: "podemos admitir que a globalização constitui um paradigma para a compreensão dos diferentes aspectos da realidade contemporânea”.

Para Iani (1998, p.191), o paradigma clássico fundado na reflexão sobre a sociedade nacional "está sendo subsumido formal e realmente pelo novo 
paradigma, fundado na reflexão sobre a sociedade global”. Ele afirma que o conhecimento acumulado sobre a sociedade nacional não é suficiente para esclarecer "as configurações e os movimentos de uma realidade que já é internacional, multinacional, transnacional, mundial ou propriamente global”.

A globalização pode, assim, suscitar a busca por um novo paradigma a partir da reflexão sobre a necessidade de uma educação criativa capaz de formar o cidadão planetário. O ensino relativo às questões ambientais tem sido consistentemente lembrado ao se considerar a necessidade de uma mudança de paradigma em que esteja inserida a interdisciplinaridade. Isso pressupõe a complexificação do raciocínio do observador, capacitando-o a apreender a complexidade da realidade a ser observada (Morin, 1996, p.30).

O saber ambiental pregado por Leff se constitui a partir de uma nova percepção das relações entre os processos naturais, tecnológicos e sociais, na qual estes últimos ocupam um lugar preponderante em sua origem e em suas vias de resolução.

A educação isolada não consegue resolver os problemas ambientais da humanidade. É importante salientar como parte da solução desses problemas, a elaboração de estratégias dos líderes políticos, ou seja, a formulação de políticas públicas, bem como a colaboração da sociedade. Pois pensar os problemas ambientais globalmente "exige conhecimento científico e perspicácia política” (Ribeiro, 2001, p.114). Um aspecto central na resolução desses problemas é a formulação de um conhecimento sobre novas bases, ou seja, a transição para um novo paradigma e que isso se reflita na educação oferecida, formadora dos cidadãos que futuramente atuarão dentro do novo paradigma nas instâncias acima referidas.

Portanto, as novas gerações em idade de formação de valores e atitudes, como também a população em geral, devem ser educadas para lidar com os principais problemas ambientais.

Castoriadis aponta a necessidade de se refletir a própria situação do saber científico contemporâneo, sua problemática interna, seu enraizamento histórico, sua função social. Ele afirma que “(...) o saber constituido pelas ciências da natureza 
(...) atravessa uma crise profunda que vem de muito longe e vai muito longe” (Castoriadis, 1987, p.161).

Nesse sentido, Santos (2001a, p.16) afirma que a crise de paradigma é não só profunda como irreversível, sendo resultado interativo de uma pluralidade de condições que ele determina como sociais e teóricas.

“Em boa verdade não há um paradigma emergente. Há antes um conjunto de 'vibrações ascendentes' de fragmentos préparadigmáticos que têm em comum a idéia de que o paradigma da modernidade exauriu a sua capacidade de regeneração $e$ desenvolvimento e que ao contrário do que ele proclama modernidade ou barbárie - é possível (e urgente) imaginar alternativas progressivas" (Santos, 2001b, p.327).

A problemática ambiental, como colocada no final do século 20, propicia crítica ao pensamento científico herdado, o que vem a requerer uma nova capacidade perceptiva da própria ciência. Este é um dos maiores desafios que esta problemática coloca: a reformulação da ciência contemporânea.

Para articular e organizar os conhecimentos, reconhecer e conhecer os problemas do mundo, Morin prega a reforma do pensamento, que deve ser realizada juntamente com a reforma do ensino e vice-versa, “a exigida reforma do pensamento vai gerar um pensamento do contexto e do complexo" (Morin, 2002a, p.26).

Duas revoluções científicas do século passado prepararam a transformação do pensamento. A primeira começou com a física quântica; o desmoronamento da idéia de que existiria uma unidade simples na base do universo; e a introdução da incerteza no conhecimento científico. ${ }^{5}$ A segunda revolução, realizada com a constituição de grandes ligações científicas, fez com que fossem tomados em consideração os conjuntos organizados, ou sistemas ${ }^{6}$, em detrimento do dogma

\footnotetext{
${ }_{5}^{5}$ Sobre os princípios da incerteza no conhecimento ver MORIN, E. A cabeça bem feita. 7.ed. Rio de Janeiro: Bertrand Brasil, 2002. p.59; MORIN, E. Os sete saberes necessários à educação do futuro. 5.ed. São Paulo: Cortez, 2002. p.79-92; PRIGOGINE, I. O fim das certezas: tempo, caos e leis da natureza. São Paulo: Unesp, 1996.

${ }^{6}$ A idéia sistêmica começou na segunda metade do século XX, a minar progressivamente a validade de um conhecimento reducionista. Como parte deste processo se encontra a Teoria Geral dos Sistemas (TGS) formulada por Bertalanffy. A respeito da TGS ver BERTALANFFY, L.V. Teoria geral dos sistemas. Petrópolis: Vozes, 1973. 351p.
} 
reducionista que imperava no século XIX. Essa revolução iniciada em várias frentes nos anos 60, gera grandes desdobramentos "que levam a ligar, contextualizar e globalizar os saberes até então fragmentados e compartimentados, e que, daí em diante, permitem articular as disciplinas” (Morin, 2002a, p.26).

Morin (2002a, p.90) afirma que "a racionalidade e a cientificidade começaram a ser redefinidas e complexificadas a partir dos trabalhos de Bachelard, Popper, Kuhn, Holton, Lakatos, Feyerabend”. Para ele, também é de se esperar “o avanço pacífico de uma reforma do pensamento”.

Capra (1982), Leff (2000), Morin (1989), Nicolescu (1999), Santos (2001) entre outros, apontam que a ciência clássica fragmenta os objetos e impede o desenvolvimento da consciência global, apesar das posições antagônicas de Leff e Santos em relação a algumas idéias de Capra e Morin.

Assim, a formação de especialistas torna mais difícil explicar e resolver os problemas complexos, porque “a especialização se fecha sobre si mesma, sem permitir sua integração na problemática global ou na concepção do objeto do qual ela só considera um aspecto ou parte dela” (Morin, 2002d, p.41).

Nessa lógica, Capra (1982, p.22) afirma:

"Um sinal impressionante do nosso tempo é o fato de as pessoas que se presume serem especialistas em vários campos já não estarem capacitadas a lidar com os problemas urgentes que surgem em suas respectivas áreas de especialização".

Um dos papéis da ciência é fornecer conhecimentos para permitir uma melhor formulação e seleção das políticas de meio ambiente e desenvolvimento no processo de tomada de decisões. Para cumprir esse requisito, é indispensável desenvolver o conhecimento científico baseado em um novo paradigma, ou seja, uma nova forma de ver e pensar a realidade, conforme explica Capra (1982), nos princípios básicos ecológicos; Leff (2002b), na sua teoria do saber ambiental; Morin (2002c) pelo paradigma da complexidade e Santos (2001a) através do paradigma emergente, entre outros. 
Nesse cenário o papel da universidade é primordial pois em uma entrevista o pró-reitor de pesquisa da Universidade de São Paulo (USP), Luiz Nunes de Oliveira apontou três grandes prioridades do seu mandato; uma delas é:

"Estimular iniciativas integradas de pesquisas (...) formando redes de pesquisadores que trabalhem em torno de um mesmo tema que seja de interesse para a sociedade, como problemas ligados ao meio ambiente, à saúde (...) um tema multidisciplinar para atrair pesquisadores de diferentes áreas” (Knapp, 2002, p.A8).

Para Raven \& Leshner (2002, p.A3) “a ajuda técnica e científica é parte necessária para a solução dos problemas dos países em desenvolvimento". Na opinião desses autores, a ciência tem avançado e a comunidade científica tem sido requisitada na busca de respostas para esses problemas, mas a maioria das nações em desenvolvimento ainda carece de infra-estrutura que permita a elas aplicar localmente os avanços científicos.

O papel da universidade é muito importante nesse contexto por ser considerada estimuladora de conhecimento com mais rigor metodológico. A realização de pesquisas científicas de alto nível, a formação de pesquisadores competentes e a elaboração de teses acadêmicas constituem funções altamente relevantes e mesmo imprescindíveis para o desenvolvimento do país.

Um exemplo da importância da comunicação do conhecimento que se dá por meio da veiculação dos artigos científicos está expresso na projeção mundial atribuída à USP, Instituição que ora estudamos: “a USP ocupa o $27^{\circ}$ lugar do mundo em termos de publicação de artigos científicos, medida pelo ISI (Institute for Scientific Information) dos EUA” (Bonalume Neto, 2004, p.8).

Sabe-se que a pesquisa tem repercussões não apenas na comunidade científica nacional, e é um dos indicadores que, bem ou mal, projetam o país entre as várias nações que contribuem para o avanço da ciência.

Segundo Melfi (2002, p.A3) no último relatório de “Indicadores de Ciência e Tecnologia e Inovação em São Paulo 2001” consta que a USP concentra $25 \%$ da produção científica nacional e que "a constância e a assiduidade da USP nas páginas de muitas publicações brasileiras e estrangeiras deve-se à excelência de sua 
pesquisa e de seu corpo docente”. Diante dessa informação Bonalume Neto (2004, p.8) afirma que "de cada 250 artigos científicos publicados no mundo, 1 tem entre seus autores um pesquisador da USP”. A julgar pela distribuição das áreas de conhecimento, devido à projeção pública dos últimos anos, deveriam destacar-se a biologia molecular e a genética, mas as campeãs são as mais estabelecidas: “ciências agrárias (3,07\% da produção mundial) e física (2,04\%)” (Leite, 2003b, p.18).

Em relação à área de ciências agrárias, ressaltamos que consta na página Orientações aos Autores, do periódico “Scientia Agricola”, que o objetivo deste é o de divulgar artigos que contribuam para o desenvolvimento das ciências agrárias. Entende-se que para ocorrer essa contribuição deve-se levar em conta uma complexa rede de fatores, dos quais podemos ressaltar a necessidade de uma sustentabilidade agrícola que utiliza modelos contrários aos modelos praticados pelo conhecimento analítico-reducionista.

\subsection{A interdisciplinaridade no campo ambiental}

"Só é útil o conhecimento que nos faz melhores" (Sócrates).

A crise ambiental estimula o surgimento de novas mentalidades no meio científico, político entre outros. A reformulação paradigmática do pensamento representaria uma revolução profunda, direcionando os enfoques ambientais para outra dimensão, pois a abordagem analítico-reducionista não contempla um aspecto essencial do mundo em que vivemos que é a interconexão dos fenômenos. A fragmentação desses fenômenos pelas disciplinas limita o avanço de um tipo de conhecimento que se tornou indispensável à confrontação da crise que nos atinge, que é o conhecimento que situa todo acontecimento ou informação em relação de inseparabilidade com seu ambiente cultural, social, econômico, político e natural.

Segundo Santos \& Sato (2001, p.47), a ênfase na interdisciplinaridade, no tratamento da questão ambiental "definiu a competência e não apenas a formação profissional específica, restrita à dimensão ecológica, como primordial à solução dos problemas ambientais". 
Sem aprofundarmos sobre o significado dos termos multidisciplinaridade e transdiciplinaridade e sem afastar a crítica de superficialidade muitas vezes dirigida aos ensinamentos interdisciplinares, parece justo dizer que o apelo à interdisciplinaridade no ensino e na aprendizagem repousa na idéia de que as disciplinas tendem a compartimentar o saber e a assumir fronteiras artificiais, isto é, fronteiras que não correspondem aos fenômenos reais a serem analisados, aos problemas a serem compreendidos e eventualmente à resolução desses problemas com a ajuda do saber.

Em 1970, ocorreu o Congresso de Nice (França) sobre Interdisciplinaridade nas Universidades cuja publicação se deu em 1972. Nesse ano, Edgar Morin publicou “O Método” em que aborda a complexidade do conhecimento como um processo de compreensão da auto-organização da matéria na perspectiva de uma ecologia generalizada. Esses avanços, a inserção da abordagem interdisciplinar nas questões ambientais, assim como o pensamento sistêmico proposto por Morin, coincidem com a proposta de fundamentar a educação ambiental ${ }^{7}$ numa abordagem holística e interdisciplinar, que foi discutida na Primeira Conferência Intergovernamental de Educação Ambiental de Tbilisi realizada em 1977 na Geórgia (ex-União Soviética).

Após a Conferência sobre o Meio Ambiente Humano de Estocolmo, em 1972, em vários países surgiram programas nacionais de pesquisas incluindo a abordagem interdisciplinar das questões ambientais.

Para Zanoni (2000, p.113), a interdisciplinaridade ambiental é aquela que se baseia em uma mesma questão central: as diversas utilizações dos recursos naturais pelo homem. Toda problemática interdisciplinar deve emergir da confrontação

\footnotetext{
${ }^{7}$ Nos documentos extraídos nas conferências de Estocolmo (1972), Belgrado (1975), Chosica (1976), Tbilisi (1977), Moscou (1987) e Rio de Janeiro (1992), a educação ambiental vem sendo definida como eminentemente interdisciplinar. A esse respeito, ver ainda CASCINO, F. Educação ambiental: princípios, história e formação de professores. 2.ed. São Paulo: Senac, 2000. p.51-63; LEFF, E. Complexidade, interdisciplinaridade e saber ambiental. In: PHILLIP JÚNIOR, A. et al. (Ed.) Interdisciplinaridade em ciências ambientais. São Paulo: Sigmus, 2000. p.20-21.

Sobre a evolução dos conceitos ambientais ver DIAS, G.F. Educação Ambiental: princípios e práticas. São Paulo: Gaia, 2003 p.98-100; GUIMARÃES, M.A. A dimensão ambiental na educação. 4.ed. São Paulo: Papirus, 2001. p.17-28.
} 
entre visões disciplinares, que modificam obrigatoriamente a visão particular de uns e de outros sobre os conceitos utilizados, os métodos escolhidos, os instrumentos empregados etc. Para essa autora, a representação da relação do homem com a natureza não pode ser nem simples nem fragmentada, mas deve tratar das interfaces entre os sistemas sociais e naturais:

"A interdisciplinaridade no campo ambiental envolve as questões que se situam na interface dos sistemas sociais e dos sistemas naturais. Essa interface compreende as interações entre as atividades humanas e o meio natural, expressas pelas suas modificações, através de práticas técnicas utilizadas pelos diferentes grupos sociais” (Zanoni, 2002, p.114).

A autora define interdisciplinaridade como uma estratégia de pesquisa que busca a conjunção de disciplinas para tratar de um problema comum ou, ainda, como o exercício de confrontação de linguagens, procedimentos, pontos de vista e conhecimentos adquiridos.

A pesquisa de caráter interdisciplinar não trata da simples troca de informações, mas da busca ativa de conexões substantivas entre os conhecimentos aportados pelas diferentes disciplinas. "Procede-se à análise crítica das supostas conexões; uma equipe interdisciplinar é, portanto, um grupo altamente diferenciado, porém aglutinado pela visão sistêmica” (Machado, 1984, p.76-77).

Floriani (2000, p.100) também considera que no âmbito da problemática ambiental os fundamentos teóricos sobre uma nova forma de produção do conhecimento não podem ser dissociados da prática interdisciplinar entendida como:

"A articulação de diversas disciplinas para melhor compreender $e$ gerir situações de acomodação, tensão ou conflitos explícitos entre as necessidades, as práticas humanas e as dinâmicas culturais".

Para ele, tal estratégia epistemológica deve buscar combater os efeitos ideológicos do reducionismo ecologista e do funcionalismo sistêmico que pensam o homem e as formações sociais como populações biológicas inseridas no processo evolutivo dos ecossistemas.

Partindo-se dessas constatações, assume-se que, em qualquer situação e diante de qualquer problema, o estado atual de uma realidade é o resultado de fatores 
físicos, químicos, biológicos, históricos e sociais que interagem segundo uma lógica interna da sociedade e sob o efeito de lógicas externas. As questões ambientais são complexas e essa complexidade exclui a visão reducionista adotando uma nova forma de produção do conhecimento que está sempre associada à prática interdisciplinar. Sem essa visão, não é possível entender e muito menos resolver os problemas e/ou as questões ambientais emergentes.

Santos (2001b, p.227) aponta várias teses enfatizando que a universidade deveria ser pautada pela ciência pós-moderna. Destaca também a importância de se garantir um desenvolvimento equilibrado das ciências naturais, das ciências sociais e das humanidades, "o que pode envolver, em curto prazo, uma política de favorecimento activo, tanto das ciências sociais como das humanidades".

O desafio do desenvolvimento da interdisciplinaridade no campo ambiental inicia-se como um processo de reconstrução social por meio de uma transformação ambiental do conhecimento - “uma educação autêntica não pode privilegiar a abstração do conhecimento. Ela deve ensinar a contextualizar, concretizar e globalizar” (Nicolescu, 1999, p.150).

Nesse contexto, direcionamos a análise das publicações entendendo como interdisciplinaridade ambiental as inter-relações entre as várias disciplinas, e dos profissionais com suas diferentes especialidades visando à convergência para uma determinada temática ambiental. Também consideramos como pesquisa interdisciplinar no campo ambiental, as pesquisas acadêmicas que envolvem a comunidade tradicional (por exemplo os estudos etnobotânicos) e outras comunidades, além do segmento acadêmico.

Apesar de existir vários estudos que mencionam o pensamento sistêmico aliado à interdisciplinaridade, são poucos os que abordam o contrário, ou seja, que na interdisciplinaridade nem sempre está nítida a presença do pensamento sistêmico. O estudo interdisciplinar deve envolver pesquisadores de diversas áreas. Pode ocorrer que algumas áreas não estejam contempladas no estudo, ou ainda, que estejam contempladas mas que seus pesquisadores possuam outros interesses, levando a que alguns aspectos do estudo sejam ocultados. Logo, o estudo deixará de ter uma 
compreensão multidimensional, e sua complexidade estará comprometida.

A partir do exposto, ressaltamos a limitação do presente trabalho quanto à identificação, nos artigos, da formação acadêmica dos pesquisadores, bem como do grau de envolvimento destes quanto ao objeto de estudo, uma vez que uma das críticas sobre a interdisciplinaridade é de que muitas vezes determinados projetos ou pesquisas se proclamam interdisciplinares e têm, entretanto, caráter multidisciplinar. Ainda em relação à formação acadêmica dos pesquisadores, esclarecemos que nos referimos aos pesquisadores que publicaram artigos nos dois periódicos científicos analisados neste estudo e que nestes periódicos apenas constavam os departamentos nos quais estavam os autores lotados, além do que, a maioria dos artigos possui mais de um autor. Já nas teses de livre-docência geralmente o autor costuma agradecer às pessoas as contribuições recebidas no desenvolvimento do trabalho. Apesar das dificuldades, foram as análises dos textos (títulos, temas, argumentos etc) apresentados pelos artigos e pelas teses, que nos permitiram interpretar e identificar se as pesquisas apresentavam ou não o caráter interdisciplinar no campo ambiental, conforme os critérios descritos na Metodologia deste trabalho.

\subsubsection{A interdisciplinaridade na Teoria Geral dos Sistemas}

Capra observou que a concepção sistêmica vê o mundo em termos de relação e integração, sendo os sistemas totalidades integradas, cujas propriedades não podem ser reduzidas a unidades menores. Logo, os sistemas não estão limitados às organizações individuais e suas partes.

"O que se preserva numa região selvagem não são árvores ou organismos individuais, mas a teia complexa de relações entre eles (...) a Teoria Geral dos Sistemas enfatiza mais as relações do que as entidades isoladas e, tal como a perspectiva sistêmica, percebe que essas relações são inerentemente dinâmicas” (Capra, 1982, p.260261).

Ressaltamos a importância da Teoria Geral dos Sistemas (TGS) que veio opor ao movimento mecanicista-reducionista, ainda que tenha sido criticada por Morin (1996, p.257), Leff (2002a, p.170) entre outros. 
Segundo Bertlanffy (1973, p.127), “a Teoria Geral dos Sistemas foi apresentada pela primeira vez em 1937 no seminário de filosofia de Charles Morris, na Universidade de Chicago". Tinha como objetivo analisar a natureza dos sistemas e a inter-relação entre suas partes, assim como a inter-relação entre eles em diferentes espaços, e ainda, as suas leis fundamentais. A obra de Bertalanffy possibilitou estabelecer, através de sua pesquisa e da lógica do seu pensamento, um elo entre várias áreas do conhecimento. Ele destacou os principais propósitos da TGS:

“1) Há uma tendência geral no sentido da integração nas várias ciências, naturais e sociais; 2) Esta integração parece centralizarse em uma teoria geral dos sistemas; 3) Esta teoria pode ser um importante meio para alcançar uma teoria exata nos campos físicos da ciência; 4) Desenvolvendo princípios unificadores que atravessam "verticalmente" o universo das ciências individuais, esta teoria aproxima-nos da meta da unidade da ciência e 5) Isto pode conduzir à integração muito necessária na educação científica” (Bertalanffy, 1973, p.62).

O autor apontava a necessidade e a importância das interações entre os sistemas e suas partes. Nota-se que a interdisciplinaridade já estava sendo citada, como descreve $1^{\circ}$ propósito da TGS. O próprio conceito interdisciplinar já constava nos argumentos dele quando se referia aos objetivos da TGS:

"Em contraposição às exigências educacionais da formação de 'Generalistas Científicos' e do desenvolvimento de 'princípios básicos' interdisciplinares são exatamente as que a teoria geral dos sistemas procura satisfazer (...) Neste sentido, a TGS parece ser um importante avanço no sentido da síntese interdisciplinária e da educação integrada" (Bertalanffy, 1973, p.78).

\subsection{O paradigma da complexidade: um desafio para a ciência moderna}

"Ninguém ignora tudo, ninguém sabe tudo. Por isso aprendemos sempre" (Paulo Freire).

Nesse item, procuramos sintetizar as contribuições fundamentadas sobre o paradigma do pensamento sistêmico descrito nas obras de Edgar Morin, uma vez que nossos argumentos para análise dos periódicos científicos e das teses de livredocência produzidos na ESALQ tomam como referência a obra desse autor. 
Segundo Capra (1996, p.53), antes da década de 40, os termos sistemas e pensamento sistêmico tinham sido utilizados por vários cientistas, mas foram as concepções de Bertalanffy, "sobre um sistema aberto e de uma teoria geral dos sistemas, que estabeleceram o pensamento sistêmico como um movimento científico de primeira grandeza".

Para evitar confusões, esclarecemos a definição dos termos sistêmico e/ou complexo, analisados neste estudo.

Os sistemas são dinâmicos, transitam incessantemente com o meio, produzindo antagonismos e, ao mesmo tempo, complementaridade. Portanto, os sistemas são complexos. É por isso que Morin sustenta que o sistema é o conceito básico da complexidade, porque não pode ser reduzido a unidades elementares, nem a conceitos simplificadores ou a leis gerais.

O pensamento sistêmico possui uma concepção holística oposta à abordagem cartesiana, que divide o todo em partes e as estuda em separado. Essa concepção estuda o todo sem dividi-lo ou reduzi-lo às partes menores, ou seja, examinao de modo sistêmico. As propriedades das partes podem ser entendidas apenas a partir da organização do todo.

Morin sustenta que estamos ofuscados pela noção reducionista de partes isoladas e separadas do todo. No entanto, ele acrescenta que quando entramos em contato com a idéia de sistema, esse ofuscamento reducionista (que só vê as partes) pode ceder lugar a um deslumbramento holístico, que só vê o todo, tornando-se impossível pensar num sistema sem pensar em seu contexto.

Assim, o pensamento sistêmico ou também denominado de pensamento complexo, é descrito por Morin (2001, p.150-151) como:

"Um pensamento-chave, pois se fundamenta no conhecimento do sentido complexo da palavra 'sistema'. Um sistema não é somente constituído de partes, ele tem qualidades, propriedades ditas emergentes, que não existem nas partes isoladas: em outras palavras, o todo é mais do que a soma das partes. Porém, algumas qualidades ou propriedades das partes são, com freqüência, também inibidas pelo todo: portanto, vale também menos do que a soma das partes”. 
As qualidades emergentes aparecem apenas quando o sistema se constitui. Outro princípio explanado por Morin é o princípio hologramático: não somente cada parte está no todo como o todo está também em cada parte; o indivíduo, na sociedade, mas também a sociedade como todo, no indivíduo. Logo, o autor afirma que a emergência e o princípio hologramático são dois princípios fundamentais para compreensão do mundo em que vivemos.

A extrema fragmentação do conhecimento, sobretudo a partir do século XIX, consagrou a separação entre o homem e a natureza. A influência de Descartes, Galileu, Leibniz e Newton contribuiu para formar o imaginário fragmentador.

\begin{abstract}
"Na comunidade acadêmica ainda domina a crença de que a ciência é o guia de ação para uma prática social racional. A tradição racionalista do iluminismo se faz presente entre nós com grande força: mesmo entre os ecologistas existem aqueles que acreditam que os técnicos e cientistas devem orientar as práticas de apropriação da natureza. Ora, a ciência e a técnica são condições necessárias mas não suficientes para garantir o uso racional dos recursos naturais. Até porque o conhecimento científico se desenvolve numa relação sujeito-objeto, enquanto que a prática social se dá numa relação entre sujeitos, em que o agir racional está condicionado por outras variáveis, sobretudo psíquicas, sociais e culturais" (Gonçalves,1998, p.56-57).
\end{abstract}

Para Gonçalves, aqueles que partem de um conhecimento científico obtido de antemão e depois, em nome dele, tentam impor à comunidade uma prática social estão consagrando essa separação entre conhecimento e ação e, dessa forma, desqualificando outros valores que se formaram em outros contextos, com outros objetivos e finalidades.

O autor afirma que em vários campos do conhecimento, a relação sujeito-objeto vem sendo repensada. Se antes todo o problema estava na melhor compreensão/explicação do objeto, não sendo considerado o outro lado da relação, isto é, o sujeito cada dia mais se impõe refletir sobre os limites do próprio sujeito que deseja conhecer e que, tenha ele consciência ou não, está inserido numa cultura, num determinado momento histórico, com as especificidades psíquicas individuais. É preciso que a comunidade acadêmica esteja atenta ao objeto, aberta e flexível, para 
adequar o método de investigação às suas particularidades.

O método de Morin (2002c) opõe-se à concepção do conhecimento reducionista inspirando-se num paradigma sistêmico ou complexo no qual a totalidade não pode ser descrita pela simplificação reducionista, pois o todo é parte de um todo ainda maior.

A ciência é igualmente complexa porque é inseparável de seu contexto histórico e social. Para Morin (1996, p.9) “a ciência é intrínseca, histórica, sociológica e eticamente complexa. É essa complexidade específica que é preciso reconhecer".

O desenvolvimento da aptidão da mente para contextualizar tende a produzir a emergência de um pensamento, que Morin chama de ecologizante, no sentido de todo acontecimento, informação ou conhecimento relacionar de forma inseparável com seu meio ambiente - cultural, político, social, econômico e natural.

"Um tal pensamento torna-se, inevitavelmente, um pensamento complexo, pois não basta inscrever todas as coisas ou acontecimentos em um 'quadro' ou uma 'perspectiva'. Trata-se de procurar sempre as relações e inter-retro-ações entre cada fenômeno e seu contexto, as relações de reciprocidade todo/partes (...) Para seguir por esse caminho, o problema não é bem abrir as fronteiras entre as disciplinas, mas transformar o que gera essas fronteiras: os princípios organizadores do conhecimento” (Morin, 2000a, p.24-25).

Para Morin, há cientistas que estão fechados em e por sua disciplina, em seu saber parcial, sem conceber que as disciplinas possam coordenar-se em torno de uma concepção organizadora comum ou se associar numa disciplina globalizante de um novo tipo, como é o caso da ecologia.

Concordando com Morin, Di Ciommo afirma que o paradigma é aquilo que está no princípio da construção das teorias, não é o resultado das observações. De acordo com ela, neste momento estamos diante de um novo paradigma, uma nova forma de explicação da realidade:

"O novo paradigma ecológico tem um sentido muito amplo e pode ser aplicado à sociedade como um paradigma social, que pode ser definido como um conjunto de conceitos, valores, percepções $e$ práticas compartilhadas por uma comunidade, dando base à sua organização” (Di Ciommo,1999, p.208). 
O pensamento sistêmico é o pensamento que se esforça para unir os diferentes elementos (como o econômico, o político, o sociólogo, o afetivo, o histórico, o biológico entre outros) constitutivos do todo. Esse pensamento interliga a todo instante as partes ao todo e o todo às partes; envolve ao mesmo tempo o observador e o sujeito, na observação da realidade.

A palavra complexus significa "o que está ligado, o que está tecido” (Morin, 2002b, p.564) ou “o que está tecido junto” (Morin, 2002d, p.38).

Para Morin \& Kern, não basta inscrever todas as coisas e os acontecimentos em um “quadro" ou "horizonte” planetário. Eles afirmam que:

"Devemos pensar em termos planetários a política, a economia, a demografia, a ecologia, a salvaguarda dos tesouros biológicos, ecológicos, culturais regionais (...). Trata-se de buscar sempre a relação de inseparabilidade e de inter-retro-ação entre todo o fenômeno e seu contexto e de todo contexto com o contexto planetário” (Morin \& Kern, 2002, p.159).

\subsubsection{A importância do pensamento sistêmico para o entendimento da complexidade ambiental}

Durante as últimas décadas, na maior parte dos ramos da ciência e da tecnologia, vem se intensificando a abordagem analítica-reducionista deixando de levar em conta o aspecto essencial do mundo em que vivemos, a saber, a interconexão dos fenômenos vivos (Viola, 2001, p.76). Na comunidade científica, segundo esse autor, essa abordagem reducionista permanece hegemônica, há o predomínio do conhecer cada vez mais sobre fatias cada vez mais restritas da realidade. Essa comunidade deve levar em conta uma preocupação com o processo de fragmentação do conhecimento em disciplinas especializadas. Viola (2001, p.78) afirma que “é indispensável a colaboração de especialistas oriundos dos mais diversos domínios de especialização para a construção de uma abordagem interdisciplinar".

O saber ambiental, na concepção de Leff, problematiza o conhecimento fragmentado em disciplinas e a administração setorial do desenvolvimento para construir um campo de conhecimentos teóricos e práticos rearticulando as relações sociedade-natureza. 
Logo, Leff questiona, a partir da complexidade da problemática ambiental e dos diversos processos que a caracterizam:

“A fragmentação e a compartimentalização do conhecimento
disciplinar, incapaz de explicá-la e resolvê-la. Entretanto, a
retotalização do saber proposto pela problemática ambiental é mais
do que a soma e a articulação dos paradigmas científicos existentes,
implica a transformação de seus conhecimentos para internalizar o
saber ambiental emergente. A necessária inter e e
transdisciplinaridade do saber ambiental transcende os alcances de
um paradigma globalizante ou a integração dos saberes diversos
por uma metalinguagem comum” (Leff, 2002b, p.148).

Assim, Leff diverge do pensamento sistêmico de Capra e de Morin, que pregam a adoção de uma metalinguagem comum pelos pesquisadores.

Viola (2001, p.79-80) considera essa metalinguagem comum como parte de uma das implicações que o sistemismo oferece ao processo de integração interdisciplinar da pesquisa ecológica humana. O autor destaca, que no nível teórico, as implicações vinculam-se aos impulsos que tal processo gera para a maturação de uma problemática fundamental de pesquisa que corresponde a um recorte competente do meio ambiente, tido como objeto científico, o que deve ser aceito de forma consensual pelas comunidades de pesquisadores associados nas várias áreas do conhecimento ciências naturais e sociais, básicas e aplicadas:

"Primeiro a possibilidade de transferência regrada de conceitos, generalizações e modelos em diferentes disciplinas especializadas. Em segundo lugar, a possibilidade de se institucionalizar uma espécie de 'língua franca', capaz, em princípio, de suprir as necessidades de comunicação entre especialistas lotados nos diversos campos de conhecimento especializados e herdeiros das mais diversas tradições de pensamento" (Viola, 2001, p.79-80).

As noções de paradigma e de universo disciplinar ficam mais esclarecidas quando associadas a seus respectivos domínios lingüísticos, conforme afirma Viola quando se refere a uma língua franca, assumindo que fora desses domínios não há comunicação, não há sociedade. Essa língua franca pode estar associada com a explicitação de um modelo teórico, sua compreensão pelos integrantes do projeto e sua aceitação pelo grupo, tornando-se assim, uma condição para o exercício da 
interdisciplinaridade.

Os ecologistas pregam o uso racional dos recursos naturais, os economistas se preocupam com o preço e com o valor de troca de mercadorias: são discursos excludentes, em que o valor de uso e valor de troca necessariamente se opõem logo, conclui-se que numa sociedade onde a tônica são as relações mercantis não é de se estranhar que o ecológico fique subordinado ao econômico (Gonçalves, 1998, p.112115).

Os economistas pouca atenção dedicam à ecologia, sendo raro o curso de economia que ofereça em seu currículo essa disciplina. O mesmo pode ser dito dos cursos de ecologia, que pouca atenção dedicam à economia.

Para Gonçalves parece existir entre esses cursos um diálogo de surdos, em que os interlocutores falam, mas não ouvem: o ecólogo fala do valor de uso e o economista fala do valor de troca. No mundo capitalista é o valor da troca que move a sociedade e não o valor do uso que é simplesmente um veículo para realização daquele; é a quantidade que se impõe à qualidade; a economia à ecologia, o abstrato (o tempo de trabalho, a produtividade) ao concreto (as qualidades de cada produto) (Gonçalves, 1998, p.112-115).

Leff (2002b, p.202-203) afirma que a articulação dos conhecimentos existentes com o sistema econômico vigente, aonde a pesquisa científica, a inovação tecnológica e a formação de profissionais para atender às demandas explícitas do mercado e do aparelho produtivo instalado, desestimulam a produção de conhecimentos e capacidade dos professores, estudantes e pesquisadores de construir uma racionalidade ambiental.

A reorientação da pesquisa, a reelaboração dos conteúdos curriculares e dos métodos pedagógicos na perspectiva do desenvolvimento sustentável leva à construção da incorporação do saber ambiental emergente nos paradigmas teóricos, nas práticas disciplinares da pesquisa e nos conteúdos curriculares dos programas educacionais. Este saber se concretiza em contextos sociais, geográficos e culturais particulares e encontra condições desiguais de assimilação nas diferentes disciplinas $e$ nas instituições de pesquisa e de educação superior. A questão ambiental gera, assim, um saber que leva a uma transformação dos conhecimentos, dos conteúdos educacionais e da gestão social dos 
recursos naturais, reorientando os sistemas de pesquisa, de educação e de produção" (Leff, 2002b, p.202-203).

Esse processo defronta-se com obstáculos que provêm da institucionalização dos paradigmas dominantes, legalizados e firmados nos critérios de valorização do conhecimento no meio acadêmico e na sociedade em geral.

Dessa forma, a necessidade de se estabelecer novos métodos para o conhecimento das questões ambientais faz com que sejam fixadas as bases que deverão provocar mudanças e transformações nas pesquisas científicas e tecnológicas.

\subsection{A escola superior de agricultura "Luiz de Queiroz": um breve histórico}

"Nem todos podem ser gênios, mas todos podem ser bons" (Carlos Drummond de Andrade).

O presente estudo escolheu para análise as publicações científicas da referida Instituição por diversos motivos, tais como: a) a ESALQ é considerada uma das mais bem conceituadas escolas de ensino superior do país e da América Latina, e b) a produção científica do seu corpo docente é bastante significativa, como exemplo, citamos o período de 1998 a 2000, cuja produção correspondeu a 34,42\% da produção total $^{8}$ da USP.

Como nosso estudo está fundamentado na análise das publicações e teses de livre-docência desenvolvidas pela ESALQ, nesse item será abordada resumidamente a história da ESALQ destacando-se alguns aspectos da sua fundação e alguns relatos sobre a postura adotada pela Instituição frente às questões ambientais.

No Brasil, no final do século XIX, existiam três cursos superiores de Agricultura: Escola Agrícola da Bahia (1875) em Cruz das Almas, Instituto Riograndense de Pelotas (1890) e o da Escola Politécnica de São Paulo (1887) sendo extinto em 1910.

Segundo Perecim (2002, p.160), “Franz W. Dafert em 1892 enviou Ernest Lehmann, agrônomo austríaco e sub-diretor do Instituto Agronômico de

\footnotetext{
${ }^{8}$ Fonte:Anuário Estatístico - http://www.sistemas.usp.br/anuario (16 a 19 Nov. 2004).
} 
Campinas (IAC) para administrar a Fazenda São João da Montanha" que viria a ser a Escola Prática de Agricultura de Piracicaba. Pois foi nesse ano que Luiz Vicente de Souza Queiroz doou as terras da fazenda São João da Montanha ao governo do Estado de São Paulo.

Uma das unidades fundadoras da $\operatorname{USP}^{9}$ (1934) foi criada em 1901 com o nome de Escola Prática de Agricultura de Piracicaba, sendo sua administração subordinada à Secretaria de Agricultura do Estado de São Paulo. Inicialmente, a Escola dedicava-se ao ensino de nível médio com maior ênfase na prática que na teoria. Sua primeira turma se formou com 7 alunos em 1903. Em 1931, passou a ser denominada Escola Superior de Agricultura “Luiz de Queiroz” (ESALQ).

Atualmente a ESALQ oferece os seguintes cursos de graduação: Engenharia Agronômica, Engenharia Florestal, Economia Agroindustrial, Ciências dos Alimentos, Ciências Biológicas e Gestão Ambiental. Possui aproximadamente 1700 alunos matriculados nesses cursos, que são oferecidos nos períodos integral e noturno.

O curso de graduação em Agronomia formou 8700 engenheiros agrônomos até 2001. O curso de Engenharia Florestal foi implantado em 1972 e graduou 518 engenheiros florestais até 2001. Além desses cursos, teve início em 1967 e foi desativado a partir de 1992 o Curso de Economia Doméstica, responsável pela graduação de 338 pessoas. Em 1997 foi implantado o Curso de Economia Agroindustrial, graduando sua primeira turma com 9 alunos em 2002. Mais recentemente, foram criados os cursos de graduação em Biologia e Gestão Ambiental (Marcos Filho, 2001, p.14).

Em 1964, a ESALQ foi a pioneira em cursos de pós-graduação da USP. Até o ano de 2001 foram registrados 15 cursos de pós-graduação e foram defendidas 3.458 dissertações de mestrado e 1255 teses de doutorado. Segundo Marcos Filho (2001, p.14), "há estimativas de que 70\% dos doutores em Ciências Agrárias, com título obtido no Brasil, sejam egressos da ESALQ”.

\footnotetext{
${ }^{9}$ A Universidade de São Paulo é considerada a primeira universidade brasileira, permitindo, com sua criação, o desenvolvimento do ensino, da pesquisa e da extensão universitária.
} 


\subsubsection{As polêmicas sobre a incorporação da dimensão ambiental pela ESALQ}

Em 1995, o professor Marcos Sorrentino apresentou sua tese de doutorado ao Programa de Pós-Graduação em Educação da Faculdade de Educação da USP. Em seu trabalho procurou analisar como a ESALQ tem contribuído para formação ambiental dos futuros engenheiros agrônomos e florestais, sem questionar se os resultados apresentados faziam surgir um novo paradigma ambiental. Concluiu que existe uma questão que parece ter se tornado consensual, ou majoritária: "a necessidade de se formar profissionais capacitados para minimizar os impactos da agricultura no ambiente, contribuindo para sua recuperação e para um ‘desenvolvimento sustentável'” (Sorrentino, 1995, p.215).

O autor esclarece que apenas esse consenso para minimizar os impactos da agricultura no ambiente não é suficiente e enfatiza:

“(...) Não é só por 'curiosidade’ que os mais distintos setores da Instituição, hoje, se aproximam da 'questão ambiental'. É por instinto de sobrevivência! Pela oportunidade, legitimidade $e$ consolidação da questão que demonstrou ter vindo para ficar e não ser mera 'moda' (...). Depoimentos de docentes que exercem papéis de decisão dentro da Instituição, relatórios de encontros de alunos, ex-alunos e de docentes apontam para a necessidade de reformulações que vão da didática em sala de aula, ao programa das disciplinas, ordenação do currículo e envolvimento dos alunos em atividades de pesquisa e extensão (...). Existe uma grande concordância sobre a importância da dimensão ambiental na formação dos engenheiros agrônomos e florestais. Embora ainda não esteja definido coletivamente o que deveria ser esta formação, o momento parece propício, em função das experiências acumuladas e da sensibilidade geral para a temática, para a definição de diretrizes e estratégias neste sentido" (Sorrentino, 1995, p.215238).

Pela importância dos diagnósticos revelados acima, que constam nos resultados da tese defendida em 1995 pelo professor Sorrentino, esperamos a partir dos resultados deste estudo, que vai de 1998 a 2002, que a Instituição já tenha definida e já tenha colocado em prática uma abordagem de ensino e pesquisa voltada para a dimensão da complexidade ambiental. Essa abordagem, apontada por vários autores já mencionados, constitui-se num dos caminhos para um novo paradigma. Do contrário, 
como o próprio professor Sorrentino mencionou, fica comprometida a sobrevivência da Instituição.

Entretanto, Marcos Filho (2001, p.14) aponta que a ESALQ, por meio de seu corpo docente e discente vem se dedicando aos problemas sociais. Sabe-se que estes constituem uma das faces da crise ambiental.

"A ESALQ constitui um ambiente onde convivem, em harmonia, docentes e estudantes dedicados à resolução dos mais profundos problemas sociais, como a questão fundiária, ao lado daqueles voltados às ciências básicas ou ao desenvolvimento de tecnologias de ponta" (Marcos Filho, 2001, p.14).

Nessa perspectiva, Klaus Reichardt, editor chefe da revista "Scientia Agricola” no período de 1992 a 2000, destaca a participação da Instituição no Projeto Genoma, revelando que:

"Esta participação exemplifica o alto nível de pesquisa que a ESALQ atingiu neste começo de século, participando de pesquisas de fronteira, multidisciplinar e interinstitucionais (...) voltando seus esforços na solução de problemas que são o desafio do novo século. O impacto ambiental da agricultura é tema prioritário, sendo jargão científico do momento a agricultura sustentável. Dentro dela, a erosão do solo merece destaque (...) A mudança climática preocupa pesquisadores da ESALQ (...) Outro tema de peso para o próximo século, e de importância fundamental na produção agrícola, é da disponibilidade e consumo de água doce" (Reichardt, 2001, p.20).

Apesar de Reichardt ter destacado a posição da ESALQ sobre temas relacionados às questões ambientais, Almeida Júnior \& Queda (2003, p.27) enfatizam a atual ausência de capacidade crítica da Instituição em relação ao desenvolvimento das suas atividades e de sua pesquisa, principalmente no que tange à pesquisa empírica "na qual as preocupações ambientais ocupam um lugar secundário, se é que ocupam algum lugar. Elas deveriam ser o centro das atenções, dada a gravidade dos problemas”.

O questionamento de Almeida Júnior e Queda sobre as questões ambientais tem sido uma constante e pertinente preocupação já alertada por renomados intelectuais como Alphandéry, Buarque, Capra, Leff, Morin, entre outros. 


\subsubsection{O Programa de Pós-graduação Interunidades “Ecologia de Agroecossistemas" da ESALQ/CENA: um caminho para a interdisciplinaridade no campo ambiental}

As universidades, assim como todos os estabelecimentos de ensino superior, devem se esforçar para contribuir de uma maneira notável para a compreensão e a resolução dos problemas ambientais atuais e também visando assegurar um futuro sustentável.

Devemos destacar o novo curso de pós-graduação interunidades em Ecologia de Agroecossistemas, que está desenvolvendo, algumas pesquisas de caráter ambiental, tendo como uma de suas linhas de pesquisa a temática "Ambiente e Sociedade”. Alguns de seus pesquisadores, aos poucos, estão abrindo um novo caminho para as pesquisas da Instituição. Esperamos que esse caminho seja ampliado e que continue aberto. Para tanto, é importante não perder de vista a principal característica do curso que é definida pelo seu caráter interdisciplinar, ressaltando o enfoque social nas questões ambientais, quer através dos planos de disciplinas, dos projetos de pesquisas ou dos núcleos de estudo.

\subsubsection{A exigência de um novo perfil para o profissional das ciências agrárias frente à problemática ambiental}

Os problemas apresentados pela crise ambiental, como já foram comentados, exigem um conhecimento baseado em um novo paradigma e este, conseqüentemente, reflete-se na educação implicando na formação do perfil profissional acadêmico. Essa tarefa de analisar que tipo de perfil profissional é formado por determinada instituição acadêmica, não é simples, "Para sua análise deve-se evitar cair nas soluções fáceis de um pessimismo reacionário ou de um voluntarismo inconseqüente” (Santos, 2001a, p.74).

Neste tópico, abordaremos o perfil do profissional das ciências agrárias por ser um dos profissionais formados pela ESALQ, com importante papel no cenário agrícola, desde a fundação da referida Instituição.

A formação do saber ambiental, sua dispersão temática e a 
especificidade de suas especializações dependem das transformações possíveis de paradigmas científicos tradicionais onde se insere o saber ambiental.

Segundo Leff (2002b, p.218), a orientação da formação de habilidades profissionais “deve considerar os contextos geográfico, cultural e político no qual deverão exercer-se, assim como as problemáticas ambientais particulares às quais deverão responder esta capacidade”.

As universidades ou estabelecimentos de ensino superior devem colocar seus estudantes face à complexidade da problemática ambiental, pois estes precisam aprender a pensar de forma sistêmica, ou seja, pensar em termos de relações, padrões, processos e conteúdos. É importante lembrar que o pensamento sistêmico baseia-se na inter-relação e interdependência essencial de todos os fenômenos físicos, biológicos, sociais, culturais entre outros, o que envolve, além dos profissionais das ciências agrárias, profissionais das outras áreas das ciências biológicas, exatas e humanas.

Kitamura \& Irias (2002, p.124-126) desenvolveram um trabalho sobre o novo perfil do profissional para o cenário rural, alertando que o profissional voltado para as áreas rurais necessita ter uma visão mais abrangente do seu campo de atuação, e que a realidade agrária brasileira atual é muito mais complexa que o simples local de produção agrícola do passado, em que a população rural era concebida como mais um recurso para a produção e para o desenvolvimento econômico.

Segundo os autores, com a contínua evolução, intensificação e diversificação de atividades econômicas-agrícolas e não-agrícolas, (atividades relacionadas ao meio ambiente preservado como o turismo rural), a gestão do espaço rural passa a depender menos de políticas agrícolas e mais de políticas públicas abrangentes e integradas entre si, que visam questões de desenvolvimento regional e local como um todo.

Esse cenário de rápidas mudanças, tanto na agricultura quanto no meio rural como um todo, faz com que o perfil tecnicista e disciplinar do profissional em geral e particularmente das Ciências Agrárias, exaltado na Revolução Verde, ficasse totalmente superado. Os autores concluem que é necessário que o profissional seja 
capaz de entender e trabalhar com outras disciplinas, relacionando o contexto geral com o específico e vice-versa. A habilidade mais importante desses novos profissionais é aprender a apreender; faz-se apreendendo e apreende-se fazendo. O aprendizado é contínuo. Essa transição movimenta-se a partir de uma etapa que privilegia a especialização para outra centrada na forma multidisciplinar e visão sistêmica.

Também nessa linha de pensamento, Buarque (1993, p.12) é bastante crítico e afirma que a universidade continua presa do mercado de trabalho, e o ambiente não é um problema porque ele não penetra no saber universitário. Segundo o autor, o único estudo ambiental é aquele que determina a ecologia como categoria do conhecimento, mas não como problema da realidade. A universidade também é presa da ideologia decorrente da Revolução Industrial, e que seu papel é o de formar profissionais, e responder nas pesquisas, à demanda, às perguntas e aos problemas formulados pelas empresas e pelos governos.

Alphandéry et al. (1992, p.79) traçam diferentes concepções sobre a ecologia praticada por alguns cientistas. Uns afirmam que os objetos teóricos e globalizantes da ecologia são relegados a um segundo plano, delimitando o estudo da ecologia não como um sistema geral de explicação do mundo, mas como um procedimento essencialmente pragmático, atribuído às participações exatas nas instâncias de decisão, objetivando uma reforma lenta dos comportamentos técnicoeconômicos cotidianos na a melhoria na qualidade de vida nos países industrializados e na supressão paulatina das injustiças que atingem o Terceiro Mundo. Outros situam a ecologia em uma fronteira flutuante entre modos de pensamento antigos e novos. Ela permitiria à humanidade libertar-se de seu excesso de confiança na ciência, na economia e na tecnologia, devido à conscientização planetária da complexidade crescente das relações entre o homem e natureza.

Essa ecologia, que é ao mesmo tempo mais científica, atuante e humana, deveria gerar nos homens de ciência, nos políticos ou nos cidadãos comuns, uma consciência e hábitos novos, combinando o respeito à natureza com as necessidades humanas.

Para outros cientistas ainda, a ecologia representaria uma verdadeira 
revolução cultural, modificando por completo os modos de agir no mundo, baseada em uma abordagem sistêmica. Essa abordagem, apesar de complexa, teve nos últimos cinquenta anos uma ampla difusão nos meios ecologistas e influenciou importantes estudiosos.

A abordagem sistêmica provém da vontade de superar a divisão científica tradicional entre as ciências, visando apreender a complexidade das relações entre natureza e cultura. Essa abordagem depende do desejo legítimo e útil, de se romper a fragmentação da ciência contemporânea e que, a partir dos anos 70 teve uma ampla repercussão no meio científico.

"Os ecologistas não podem ficar prisioneiros do mito da razão técnica, sendo uma armadilha ideológica que a sociedade instituiu e que se torna muitas vezes co-responsável pelos problemas que enfrentamos. As técnicas são apenas vistas como meios concebidos para realizar determinados fins (...). A técnica é uma condição necessária, mas não suficiente para resolver os problemas que a humanidade defronta” (Gonçalves, 1998, p.123-124).

Gonçalves afirma ser necessário esclarecer que a solução dos problemas ambientais não é simplesmente de natureza técnica, mas principalmente uma opção político-cultural. A técnica deve servir à sociedade e não esta ficar subordinada àquela.

Entretanto, Buarque acredita que, embora seja prisioneira do mercado que define as demandas por profissões e pelas pesquisas, a universidade tem um poder de antecipação maior do que o setor empresarial. O que permite uma margem de trabalho para as pesquisas ambientais que o setor privado não fará. Mas, mas para isso:

“A universidade deverá se libertar da prisão ideológica que assume a arrogância antropocêntrica, o otimismo míope e a crença do mercado; ela precisa entender que o mundo vive um momento de ruptura de um paradigma sócio-econômico para outro, onde a natureza passará a ter um valor em si” (Buarque, 1993, p.14-16).

Para o autor, ao organizar o pensamento apenas por categoria do conhecimento, a universidade perdeu a capacidade de pensar os problemas reais; a universidade que desejar abordar o problema ambiental terá que modificar sua estrutura, necessitando ser um centro de promoção de uma consciência humanista. O engenheiro 
que não tiver uma formação humanista não compreenderá toda a dimensão do problema energético, ele continuará imaginando que a solução se encontra apenas na ampliação da oferta e do aprimoramento dos meios tradicionais. Não verá a relação da crise ecológica com as características sociais; não perceberá a necessidade e possibilidade de mudanças nessas características; não compreenderá o problema em sua dinâmica histórica. Somente a incorporação de todas essas abordagens vão permitir que o universitário tome consciência de que o problema do meio ambiente é um problema da relação homem-natureza, do papel e do projeto de civilização.

Para Sá (1993, p.118-119) não é possível resolver um problema ambiental como se este fosse unidimensional. Um problema ambiental "é um problema de: engenharia, zoologia, biologia, ciências humanas etc”. O autor ressalta que a interdisciplinaridade não é um conjunto de disciplinas, mas uma equipe de pessoas que praticam disciplinas, por causa de um tema, de um problema, por causa da sua prática de responsabilidade social.

\title{
2.5 Conceitos, funções e tipos de periódicos científicos
}

\begin{abstract}
"A comunicação situa-se no próprio coração da ciência. É para ela tão vital quanto a própria pesquisa, pois a esta não cabe reivindicar com legitimidade este nome enquanto não houver sido analisada e aceita pelos pares. Isso exige, necessariamente, que seja comunicada" (A.J. Meadows, 1999).
\end{abstract}

A seguir apresentamos algumas considerações sobre os periódicos científicos, que são considerados uma forma de comunicação científica e são destinados à comunidade científica.

Os periódicos foram criados em 1665 e transformaram-se de um veículo com finalidade de publicar notícias científicas, em um veículo de divulgação do conhecimento que se originou das atividades de pesquisa” (Miranda, 1996, p.380).

Segundo Meadows (1999, p.7), os periódicos científicos surgiram na metade do século XVII por várias razões, tais como: a expectativa de seus editores em relação ao lucro e a crença de que para fazer novos descobrimentos era preciso que houvesse um debate coletivo. Mas o motivo principal foi a necessidade de comunicação, 
do modo mais eficiente possível, entre uma clientela crescente interessada em novas realizações científicas.

A Associação Brasileira de Normas Técnicas (ABNT), (1978, p.9-12) define periódicos como:

"Publicações editadas em fascículos, números ou pares, a intervalos prefixados, por tempo indeterminado, com a colaboração de várias pessoas, sob a direção de uma ou de várias, em conjunto ou sucessivamente, tratando assuntos diversos, segundo plano definido".

Nos periódicos estão as tendências seguidas pelas pesquisas em várias nações e as prioridades para as várias áreas de pesquisa científica, além de ser um dos principais veículos para o registro do conhecimento e ser capazes de atingir grande número de leitores por seu caráter permanente.

Segundo Herschman (1970, p.37-42), o periódico científico possui três funções básicas:

"É um registro oficial e público da ciência, consolidando o reconhecimento de prioridades de descobertas elou idéias (função memória); constituí um meio para difundir tanto a informação primária como a secundária (função disseminação) e é uma Instituição social que confere prestígio e recompensa aos autores, aos membros do conselho da redação e aos editores (função social)”.

Gomes (1990, p.98) classifica as revistas especializadas em ciência e tecnologia em dois tipos: revistas de disseminação e revistas de divulgação científica. Ambas têm como objetivo primordial a difusão da ciência. As de disseminação veiculam o conhecimento e são produzidas por pesquisadores, dirigidas aos pares e, por isso mesmo, veiculam textos altamente especializados, que provavelmente só serão compreendidos por profissionais da área do conhecimento do assunto abordado. Por essas características, consideramos os periódicos deste estudo como revistas de disseminação. Ainda para Gomes, as revistas científicas difundem a ciência com o propósito de mostrar ao público a validade das pesquisas relatadas e gerar mais conhecimento; são produzidas por cientistas visando atingir os especialistas e a linguagem é acessível apenas entre eles. 
Segundo Meadows (1999, p.166) os artigos de periódicos sujeitos à avaliação e os livros científicos ainda são considerados como as publicações definitivas dos resultados de projetos de pesquisa, sendo portanto, os itens preferencialmente lidos e citados pelos colegas.

Ao término do trabalho, os autores geralmente têm de decidir sobre a revista à qual encaminharão um artigo. Para tanto, Meadows aponta dois fatores fundamentais envolvidos na escolha do periódico: o prestígio do periódico na comunidade científica, e o público alvo atingido pelo periódico.

Para um periódico ter prestígio não basta publicar as melhores pesquisas pelos melhores pesquisadores, mas deve antes possuir certas características, por exemplo, gozar de reputação consolidada no meio da comunidade científica. Isso implica que o periódico já deva existir há algum tempo. Em termos de tempo de existência o periódico “Scientia Agricola” começou a ser veiculado há décadas, esse fato consta nas informações extraídas do livro comemorativo "Esalq 100 anos: um olhar entre o passado e o futuro” (2001, p.46-91):

"No final da década de 80 foi criada a primeira Comissão de Pesquisa (...) que tinha como objetivo organizar as atividades de pesquisa, favorecendo a geração e a difusão do conhecimento nas diversas áreas de competência da Instituição (...) Atualmente, é projeto importante a revista 'Scientia Agricola', uma evolução dos 'Anais da Escola Superior Luiz de Queiroz', iniciados em 1951. O último ano dos Anais foi o de número 48, em 1951. Hoje, a 'Scientia Agricola' encontra-se no exemplar de número 58, de 2001. É uma revista de circulação internacional, considerada de nível " $A$ ” pela Capes, amplamente indexada e também disponível em versão virtual pela Internet".

Ainda em relação à indexação da revista “Scientia Agricola”, salientamos que incluímos no apêndice deste trabalho uma análise de uma das bases de dados na qual está indexada a respectiva revista. 


\subsubsection{Difusão, Disseminação e Divulgação Científica}

O cuidado para com o habitat será coletivo se houver um processo coletivo de educação, em que a maioria participe, tenha acesso à informação e faça troca de saberes. Essa informação se dá de várias maneiras: por difusão, disseminação e divulgação e através de diversos veículos como: rádio, jornal, revista, televisão, internet etc.

Conforme definição de Kunsch (1992, p.62-63) a difusão científica é um conjunto amplo de todos os recursos e processos utilizados para veicular informações científicas e tecnológicas (exemplo: banco de dados, reuniões científicas, programas de rádio e TV dedicados à ciência e à tecnologia etc).

Já a disseminação científica atinge um universo mais restrito ou um determinado segmento de público selecionado que conhece o assunto. É a troca de informações científicas entre especialistas de uma área de conhecimento e de outras, desde que haja domínio conexo do conteúdo e dos códigos utilizados na mensagem. A divulgação científica, por sua vez, constitui-se no uso de recursos, técnicas e processos para transmitir informações científicas e tecnológicas numa linguagem acessível ao público em geral, em diferentes meios de comunicação.

Nota-se que a difusão está presente tanto para disseminar como para divulgar, ressaltando que a diferença entre disseminação e divulgação é que a primeira está direcionada a um público seleto (especialistas, docentes, alunos, enfim, a comunidade científica) e a segunda está direcionada ao público em geral. Neste estudo, há ênfase na disseminação, pois analisamos tanto as teses de livre-docência como revistas especializadas cujo público alvo é a própria comunidade científica. Assim, destacaremos a seguir questões relacionadas à disseminação científica.

Segundo Bueno ${ }^{10}$, citado por Destácio (2002, p.94), não se pode confundir divulgação científica, por vezes denominada popularização ou vulgarização da ciência, com disseminação científica. Esta última "pressupõe a transferência de informações científicas e tecnológicas, transcritas em códigos especializados a um

\footnotetext{
${ }^{10}$ BUENO, W. da C. Jornalismo científico no Brasil: os compromissos de uma prática independente. São Paulo,
} 1984. Tese (Doutorado) - Escola de Comunicação e Artes, Universidade de São Paulo. 
público seleto, formado por especialistas”. Logo, os periódicos científicos fazem parte desse universo. Tanto disseminam como divulgam informações com origem na ciência e tecnologia. São formas de difusão científica.

Miranda (1996, p.375-376) enfatiza como atividades associadas à disseminação científica aquelas que "conferem tanto ao produto quanto aos produtores a projeção necessária à sua visibilidade no meio social em que produção científica produto e produtores se inserem”. Esses produtos vêm sendo valorizados pela comunidade científica desde os primórdios de sua história e são: congressos e reuniões científicas, assim como o periódico científico.

Embora nosso estudo esteja voltado à disseminação das pesquisas, ressaltamos a preocupação de vários autores como Chauí, Candotti, Bucci, Población, Leite, Targino, Kunsch, Reis, Pavan, Kreinz entre outros, com relação à importância do papel da divulgação científica, uma vez que o ato de divulgar equivale à transformação do discurso científico cifrado ou especializado do cientista em linguagem pública.

Conforme relata Lima (http://www.revistapesquisafapesp.br, 20 Out. 2002) os meios de ligação entre a ciência profissional e a comunidade em geral têm sido motivo de preocupação sistemática por parte dos cientistas e dos governantes. Esse fato foi atestado em 1831 com a criação da British Association for the Development of Science. Anteriormente, no século XVII, Francis Bacon já insistia na questão da responsabilidade da ciência para com a humanidade. Um esforço de divulgação dos avanços da ciência e da tecnologia, para ele, era não só uma necessidade como um dever social. Além disso, devemos destacar o desenvolvimento do jornalismo científico, crescente em nossos dias, tanto em jornais diários como em revistas científicas.

\subsubsection{Conceitos e funções da comunicação científica}

A comunicação científica é definida por Garvey (1979, lv.) como:

"A comunicação que incorpora as atividades associadas à produção, disseminação e uso da informação, desde o momento em que o cientista concebe uma idéia para pesquisar, até que a informação acerca dos resultados seja aceita como constituinte do conhecimento científico". 
Segundo o autor, como conjunto de atividades que interferem na produção pode-se entender aquelas que contribuem para viabilizar um produto enquanto veículo (suporte físico) de comunicação do conhecimento.

A comunicação científica é indispensável à atividade científica, pois permite somar os esforços individuais dos membros da comunidade científica. Eles trocam informações com seus pares, emitindo-as para seus sucessores.

A informação é a essência da comunicação científica e, por conseguinte, a sua produção é o objetivo primordial da comunidade científica. Assim, os pesquisadores transmitem seus conhecimentos recém-gerados à comunidade, e acabam por serem reconhecidos como cientistas. A confirmação, o reconhecimento desse caráter se dá em dois níveis "De início, o reconhecimento dos pares, e posteriormente a confirmação institucional, que exige produção intensa de publicações originais" (Targino, 2000, p.55).

Massarini \& Moreira (1990, p.32) identificaram três linhas na comunicação científica: os discursos científicos primários (teses, periódicos, livros) escritos por pesquisadores para pesquisadores (que é a linha utilizada por este estudo); didáticos (manuais científicos para ensino) e os da divulgação científica (revistas, jornais etc) - escrita por pesquisadores para o público em geral. Concluem que a ciência, sendo um empreendimento retórico, depende essencialmente da eficácia e da precisão das práticas de comunicação que adota. Cada discurso serve a um propósito determinado e busca atingir um público específico.

Menzel $^{11}$, citado por Targino (2000, p.54) sistematiza as funções da comunicação na ciência como: fornecer respostas a perguntas específicas; concorrer para a atualização profissional dos cientistas no campo específico de sua atuação; estimular a descoberta e a compreensão de novos campos de interesse; divulgar as tendências de áreas emergentes, fornecendo aos demais cientistas a idéia de relevância de seu trabalho; testar a confiabilidade de novos conhecimentos diante da possibilidade de testemunhos e verificações; redirecionar ou ampliar o rol de interesse dos cientistas e

11 MENZEL, H. Scientific communication five themes from social science research. American Psycologist, Washington, v.21, n.10, p.999-1004, Oct. 1966. 
fornecer feedback para aperfeiçoamento da produção do pesquisador. Essas funções, segundo a autora, são cumpridas por pessoas que possuem objetivos comuns. Dessa forma, a comunicação científica obedece às práticas estabelecidas pela comunidade científica, termo que designa tanto a totalidade dos indivíduos que se dedicam à pesquisa científica e tecnológica como grupos específicos de cientistas, segmentados em função das especialidades, e até mesmo de língua, nações e ideologias políticas.

Nota-se que as funções: estimular a descoberta e a compreensão de novos campos de interesse e redirecionar ou ampliar o rol de interesse dos cientistas representam um caminho para a prática interdisciplinar e a partir delas refletimos se os periódicos analisados neste estudo possuem ou não uma tendência para a interdisciplinaridade.

Destacamos dos conceitos de Menzel que pela análise das informações científicas veiculadas pelos artigos científicos e pelas teses de livre-docência, torna-se possível identificar as tendências de áreas emergentes, inseridas nessas as abordagens da complexidade ambiental, publicadas pelas revistas "Scientia Agricola", "Scientia Forestalis” e pelas teses de livre-docência da ESALQ, sendo os artigos produzidos legitimados pelos pares e as teses apresentadas legitimadas pela Instituição.

\subsubsection{A responsabilidade social do pesquisador na divulgação da pesquisa ambiental}

Os pesquisadores podem visualizar a divulgação dos resultados das suas pesquisas como expressão de sua função social como pesquisador. Para tanto, é necessário que suas informações científicas sejam repassadas não somente à comunidade científica, mas também à população.

De acordo com Acot (1990, p.41), surgiram em 1890, nos Estados Unidos, as publicações de caráter ecológico, sendo a obra do botânico oficial do Estado de Minnesota, Conway McMillan uma das primeiras publicações americanas de natureza ecológica, datando de 1897.

Em 1970 foi lançada a revista "Ecologist” na Grã-Bretanha, vindo a ser "um poderoso meio de contribuição e fermentação de idéias na área ambiental” 
(Dias, 2003, p.34).

O capítulo 35 da Agenda 21 intitulado “A Ciência para o

Desenvolvimento Sustentável” aborda o papel e a utilização das ciências no apoio ao manejo cauteloso do meio ambiente visando à sobrevivência e ao desenvolvimento da humanidade: “Um dos papéis da ciência é oferecer informação para permitir uma melhor formulação e seleção das políticas do meio ambiente e desenvolvimento no processo de tomada de decisões" (http://www.mma.gov.br/port/se/agen21/cap35.html, 28 Fev. 2004).

Segundo Seifert (1998, p.113), desde os anos setenta a pesquisa ambiental vem se ampliando e conseguiu caracterizar, em muitos campos, os sintomas de degradação e desenvolver indicadores de modificações ambientais que alimentaram bases de dados associadas a programas de modelagem ambiental. Logo, pode-se obter previsões confiáveis sobre as tendências relativas ao ambiente e implementar medidas preventivas. O autor afirma que "em muitas áreas da pesquisa ambiental, o trabalho é de caráter interdisciplinar e de natureza eminentemente preventiva”.

O avanço das pesquisas científicas depende do intercâmbio da troca de observações e experiências entre cada membro da comunidade científica. A necessidade de trocar dados, desenvolver teorias e experiências simultaneamente, e modificar idéias, tudo isso faz com que os cientistas se envolvam com comunicação.

A pesquisa científica e a divulgação de seus resultados são atividades inseparáveis. Divulgar resultados não é um complemento, mas uma das etapas essenciais do trabalho de investigação, que só se complementa quando o trabalho for comunicado.

Para Le Coadic (1996, p.27), sem informação, a ciência não pode se desenvolver e viver: "Sem informação a pesquisa seria inútil e não existiria o conhecimento (...) a informação só interessa se circula, e, sobretudo, se circula livremente".

Mas para a circulação da informação ocorrer livremente há em seu caminho muitos percalços, principalmente encontrados nas universidades públicas e que são criticados por diversos autores. Targino (2001, p.33) mostra que os pesquisadores 
acadêmicos confundem divulgação de resultados com a indústria da pesquisa e papers. Portanto, o objetivo máximo da investigação científica acaba sendo substituído - busca de respostas para um problema determinado - por produção meramente quantitativa de artigos e papers. A intenção primordial passa a ser garantir pontos para ascensão profissional, conceitos mais elevados para os programas de pós-graduação e concessão de benefícios. Ao contrário, a autora defende que os cientistas devem "visualizar a divulgação de resultados como expressão de sua função social como pesquisador”.

Nessa perspectiva, podemos notar que não há ciência sem comunicação e não há comunicação sem informação. A comunicação científica é indispensável à atividade científica. Mas a produção da ciência não se dá alheia ao contexto social em que ela se insere, devendo ultrapassar as fronteiras da comunidade de usuários mais imediatos, sob o risco de se tornar estéril e inútil.

Considerando que a complexidade dos problemas ambientais está inserida no contexto social, cultural, econômico, político etc, torna-se fundamental que esses contextos sejam tratados na pesquisa acadêmica, resultando numa produção científica que venha a contribuir para a reflexão e solução dos problemas ambientais.

Nesse sentido, Ribeiro (2003, p.A3) destaca a responsabilidade social do pesquisador aliada à qualidade de pesquisa:

"Não podemos pesquisar sem levar em conta nossa responsabilidade social. Numa sociedade mais justa, sem miséria ou devastação ambiental, poderíamos pensar só por pensar. Aqui não. É como cientistas que melhor podemos contribuir para o avanço do país. Não podemos abrir mão da qualidade de pesquisa".

Chaú (2001, p.153) formula um conceito geral de excelência na pesquisa e define pesquisa excelente como aquela que, tratando de algo particular, o faz de tal maneira que seu alcance, seu sentido e seus efeitos tendam a ser universalizáveis, e que poderá vir a ser publicada e conhecida internacionalmente. Ressaltamos, porém, que há áreas de estudos, principalmente nas ciências humanas, em que são realizadas pesquisas com particularidades locais e regionais, sem deixar de ter caráter de excelência. 
Além da responsabilidade do pesquisador há também a responsabilidade da universidade, conforme destaca a professora da Escola de Comunicação e Artes da Universidade de São Paulo (ECA/USP), Margarida Kunsch, que desenvolveu trabalho sobre a divulgação das pesquisas. Para a autora, a maioria das universidades brasileiras ainda não se conscientizaram da necessidade de terem em sua estrutura organizacional um sistema planejado de comunicação integrada, capaz de difundir, de forma eficaz a sua produção científica. A hipótese do seu trabalho era a de as universidades, em geral, não possuírem uma política clara em relação à difusão de sua produção científica e que somente algumas universidades brasileiras têm a preocupação de investir na difusão de sua produção científica.

Leite (2004, p.A3) ressalta que a universidade é uma instituição que tem como objetivos fundamentais a geração e a difusão do conhecimento.

“A primeira dessas tarefas é realizada por meio da pesquisa, e a segunda pelo ensino e diversas formas de transferências de conhecimento para outros segmentos da sociedade”.

Na mesma linha de pensamento de Kunsch, Población enfatiza que a pesquisa produzida pela universidade é ignorada pela maior parte da população, pois a sociedade não recebe esses conhecimentos. Esse desconhecimento decorre de vários fatores, entre eles, é destacado o da disponibilidade reduzida do espaço que os meios de comunicação oferecem para que o grande público seja informado das pesquisas e da alta relevância dessas atividades. A autora afirma que "a projeção da universidade, como centro gerador de novos conhecimentos, incontestavelmente se efetiva através da pesquisa” (Población,1994, p.127-129).

\subsubsection{A busca da identificação de um novo paradigma através da comunicação científica}

Francis Bacon escreveu no século XVII sobre as duas principais razões pelas quais valeria a pena o homem conquistar novos conhecimentos: o que representa em sí mesmo e as suas aplicações. Para ele, o aumento do conhecimento está 
"inextricavelmente ligado à sua comunicação, não exclusivamente com as gerações contemporâneas, mas também com as gerações subseqüentes” (Meadows, 1999, p.2).

Pelo fato de os problemas ambientais colocarem em xeque o modo de produção de uma sociedade, o modo de vida, os conhecimentos etc, o enfoque da pesquisa ambiental deveria redirecionar em profundidade o atual paradigma e estabelecer novos métodos para o conhecimento das questões ambientais, fazendo com que sejam fixadas as bases que deverão provocar mudanças e transformações nas pesquisas científicas e tecnológicas.

Nesse contexto, a comunicação científica pode ser considerada como um importante instrumento de análise na identificação dos paradigmas utilizados por pesquisadores de uma determinada comunidade científica.

Aqui abrimos um parêntese para um exemplo de periódico fundado em 1940 pelo educador americano Fritz Kunz, intitulado "Main Currents in Modern Thought”. Já nessa época seus artigos tratavam da relação homem e natureza, sujeito e objeto, interioridade e exterioridade; em suma, já havia uma preocupação, como pode ser comprovado em seus artigos, da relação do homem com a natureza.

"O periódico provocou um impacto na cultura americana, sem alarde, por mais de trinta anos. Seu objetivo era promover a livre associação daqueles que trabalham conjuntamente para integrar a soma do conhecimento através da totalidade das coisas: natureza, homem e sociedade, considerando o universo uno, verossímil, inteligível, harmonioso" (Weber,1986, p.11).

Segundo a autora citada, o "Main Currents in Modern Thought” circulou até 1975, conquistando colaboradores que já nesse período (1940-1975) trabalhavam nas fronteiras de seus campos de conhecimentos: Heisenberg, Eugene Wigner, Von Bertalanffy, Jean Charon entre outros. “Em 1972 o periódico publicou um artigo de um jovem físico desconhecido, Fritjof Capra, extraído de um livro publicado posteriormente, The tao of physics" (Weber, 1986, p.11). 


\section{METODOLOGIA}

Foram analisadas:

- As revistas científicas produzidas pela ESALQ e desta em parceria com o Instituto de Pesquisas e Estudos Florestais (IPEF) que tivessem sua periodicidade consolidada, ou seja, a "Scientia Agricola" e a "Scientia Forestalis", no período de 1998 a 2002;

- Por meio do levantamento dos Currículos Lattes dos docentes da ESALQ, quais as demais revistas nacionais e internacionais (além das citadas acima), que os pesquisadores da Instituição utilizaram no período de 1998 a 2002 para publicação de suas pesquisas;

- As teses de livre-docência defendidas pelos docentes da ESALQ no período de 1998 a 2002;

- Buscou-se conhecer as teses de livre-docência e os artigos dos periódicos de 1998 a 2002, que tenham adotado uma abordagem sobre as questões ambientais dentro de um novo paradigma científico;

- As características estruturais e administrativas das revistas baseadas no modelo proposto por Población et al. (2002, p.361-366). 


\section{A coleta de dados}

Em face aos nossos objetivos, o presente estudo realizou a pesquisa documental na Biblioteca Central da ESALQ e documentos de bibliotecas digitais e virtuais que permitiram a realização do levantamento das teses de livre-docência, das revistas científicas e dos Currículos Lattes, compreendidos no período de 1998 a 2002. A escolha desse período deveu-se ao fato de considerarmos para análise as pesquisas mais recentes da Instituição e também devido à periodicidade regular dos periódicos, o que representa significativo número de artigos publicados.

Além de utilizarmos os periódicos como objeto de análise, destacamos a relevância da inclusão das teses de livre-docência a partir de Nojimoto (1996, p.71), pois o autor considera esse tipo de tese como:

“(...) reflexo da essência da pesquisa universitária por não possuírem orientações formais, são livres de restrições de temas, espaço, são desenvolvidas por pesquisadores com formação científica formal completa, são consideradas a base da pesquisa da Instituição e por fazerem parte da carreira universitária do pesquisador".

As teses de livre-docência, como o próprio nome diz, são realizadas por docentes que a partir da pesquisa realizada, legitimam o saber desenvolvido pela comunidade científica.

Logo, as teses de livre-docência, sendo consideradas a base da pesquisa da Instituição onde são produzidas, constituem-se em indicadores adequados para a caracterização e o questionamento do tratamento que a mesma tem dado às questões ambientais.

\section{A análise dos dados}

Para análise dos dados das teses de livre-docência e dos artigos foram utilizadas tanto a análise qualitativa quanto a quantitativa, e também esta última para a análise dos Currículos Lattes. Procuramos, não identificar, as teses e os artigos, pois a crítica não é pessoal. Para tanto, as teses foram identificadas por números e os artigos foram referidos pelas revistas. 
Quanto à análise das características estruturais e administrativas das revistas, utilizamos o modelo proposto por Dinah Aguiar Población (Población et al., 2002, p.361-366). Essa análise foi necessária porque nossos dados foram extraídos da comunicação científica. Analisar suas estruturas significa identificar uma série de fatores, entre eles o conteúdo científico das revistas, uma vez que o presente estudo tem como enfoque a temática ambiental. Além do conteúdo científico analisamos a periodicidade das revistas se as mesmas são ou não consolidadas no mercado, entre outros fatores que mencionaremos mais adiante.

\section{O universo da amostragem}

Para análise dos dados foi feito levantamento de todas as teses de livredocência e de todos os artigos das revistas “Scientia Agricola” e "Scientia Forestalis", correspondentes ao período de 1998 a 2002. A partir desse levantamento utilizou-se para análise, uma amostragem correspondente a 20\% do total de artigos das revistas. Essa porcentagem é considerada representativa por diversos estudos de metodologia, principalmente quando é extenso o número de dados a serem analisados. A análise dos Currículos Lattes foi feita a partir de uma listagem fornecida pela secretaria do Programa de Pós-Graduação Interunidades em Ecologia de Agroecossistemas, na qual constavam os nomes de todos os docentes e seus respectivos departamentos. Dessa listagem utilizamos uma amostragem de $20 \%$ do total de docentes. Como os departamentos possuem diferentes quantidades de docentes utilizamos para cada departamento uma amostragem de $20 \%$ do total de docentes por departamento, estes foram identificados por números e sorteados aleatoriamente. Quanto às teses, analisamos todas aquelas defendidas no período citado anteriormente.

\section{A análise qualitativa}

Como análise qualitativa consideramos a análise de conteúdo dos artigos científicos e das teses de livre-docência. Os conteúdos dos artigos e das teses podem abranger os mais variados aspectos e, em geral, apresentam temas ou abordagens novas, diferentes, atuais. Portanto, por meio da análise do conteúdo das pesquisas da 
ESALQ, pudemos identificá-las sob dois aspectos: $1^{\circ}$ ) Caráter Interdisciplinar e $2^{\circ}$ ) Se estavam inseridas no novo paradigma (pensamento sistêmico).

Parâmetros de análise para caracterização da pesquisa interdisciplinar no campo ambiental

Para que as pesquisas sejam consideradas de caráter interdisciplinar é preciso haver a inter-relação de duas ou mais disciplinas, que são conduzidas por profissionais de diferentes especialidades de conhecimento visando à convergência para uma determinada temática. Também consideramos como pesquisa interdisciplinar, as pesquisas acadêmicas que envolvem a comunidade tradicional (por exemplo estudos etnobotânicos) com outras comunidades, além do segmento acadêmico.

\section{Parâmetros de análise para caracterização da pesquisa inserida no novo paradigma (pensamento sistêmico)}

Para as pesquisas serem consideradas como aliadas ao pensamento sistêmico, precisam estar fundamentadas sob todos os setes aspectos que o compõem, considerando-se também o pensamento do contexto, pois tais aspectos estão interligados ao pensamento do contexto, de acordo com Morin.

Os sete aspectos abaixo constituem-se numa síntese do pensamento sistêmico extraído de Morin \& Kern (2002, p.159-160). Assim, a construção do pensamento sistêmico necessita de:

1- Um pensamento que ligue o que está separado e compartimentado, estabelecendo a relação entre a parte e o todo.

"A complexidade sistêmica manifesta-se, sobretudo, no fato de que o todo possui qualidades e propriedades que não se encontram no nível das partes consideradas isoladas, e inversamente, no fato de que as partes possuem qualidades e propriedades que desaparecem sob o efeito das coações organizacionais do sistema” (Morin,1996, p.291).

2- Um pensamento radical, que vai à raiz dos problemas; a maioria dos problemas ambientais tem suas raízes em fatores sociais, econômicos e culturais;

3- Um pensamento multidimensional, não isolando uma parte do todo, assim como as 
partes umas das outras. A aspiração do pensamento à complexidade não quer todas as informações sobre o fenômeno estudado, mas busca respeitar suas diversas dimensões. O ser humano é ao mesmo tempo um se biológico, psíquico, social, afetivo e racional; 4- Um pensamento organizador ou sistêmico que conceba a relação todo-partes-todo, tal como nas ciências ecológicas e da Terra;

5- Um pensamento ecologizado que não isole o objeto de estudo, mas o considere em sua relação auto-eco-organizadora (trocas com o ambiente ou ecossistema), com seu ambiente - cultural, social, econômico, político, natural;

6- Um pensamento que conceba a ecologia da ação e a dialética da ação capazes de modificar ou anular a ação empreendida.

"A ecologia da ação é, em suma, levar em consideração a complexidade que ela supõe, ou seja, o aleatório, o acaso, a iniciativa, a decisão, o inesperado, o imprevisto, a consciência de derivas e transformações” (Morin, 2002d, p.87);

7- Reconhecimento de que o pensamento está inacabado e “dialoga” com a incerteza, sobretudo na ação, porque é próprio da ação operar com o incerto.

Ainda dentro do conceito de pensamento sistêmico cabe definir o pensamento do contexto.

Conforme explica Morin (2002d, p.36) no pensamento do contexto devemos considerar que "O conhecimento das informações ou dos dados isolados é insuficiente. É preciso situar as informações e os dados em seu contexto para que adquiram sentido".

As hipóteses deste estudo foram verificadas com base nas idéias de Edgar Morin. Certamente existem outros pensadores que poderiam compor esse universo, mas a escolha de Morin foi intencional, pois possui uma ampla trajetória intelectual, sendo autor de várias obras importantes para o estímulo da reflexão sobre o pensamento sistêmico na ciência, e que norteia a linha de raciocínio deste estudo.

“A obra de Edgar Morin é multiforme. Na França foi reconhecida a obra do sociólogo e, mais recentemente, a do sociólogo da organização. Na Inglaterra, com mais facilidade, a do intelectual de esquerda (...). Nos países da América Latina e Japão, a do pensador da complexidade” (Bianchi, 1999, p.119). 
"Conhecer Morin é ir ao encontro de uma vida e obra tecidas juntas, é caminhar por uma estrada onde a pessoa e o pensador são um só e, ao mesmo tempo, muitos (...) Pensador de uma cidadania terrestre que propõe uma ética de solidariedade, transita em diferentes contextos quer regionais, quer mundiais, de forma a contribuir para a construção do pensamento complexo" (Vega et al., 2001, p.8-21).

Entre os anos 1970 e 1971, o autor se dedicou à compreensão do pensamento sistêmico, da biologia e da cibernética para chegar a um projeto de reflexão sobre antropo-biologia. Em 1973 publicou “O Paradigma Perdido: A Natureza Humana”, que nos convida a rever as categorias do humanismo; o homem biológico, social, cultural e religioso se torna um complexo. O respectivo livro foi o ponto de partida para a construção de o "Método”, considerada sua obra mais completa e importante, que propõe a uma reforma do pensamento, sendo composta por cinco volumes e traduzidos para diversas línguas.

O método do pensamento sistêmico é a ativação de princípios anticartesianos e pós-cartesianos, no sentido de não rejeitar os resultados da ciência reducionista, mas descobrir a possibilidade de recusar suas limitações, no que concerne, pelo menos, à modelização dos problemas propostos.

"Se a complexidade, essa modelização do pensamento moriniano, é um paradigma pós-cartesiano, deve permitir-nos não apenas formular os problemas de outra maneira, mas inventar as soluções” (Bianchi (1999, p.125).

\section{Parâmetros para análise das características estruturais e administrativas das revistas científicas}

Para análise deste tópico, como já mencionamos, utilizamos o modelo proposto por Población et al. (2002, p.361-366) que se baseia no levantamento das principais características das revistas selecionadas, tais como: a) Conteúdo - caráter científico; b) Estrutura dos artigos - formato, idiomas, sumários, palavras-chaves; c) Gestão Editorial - abordagem de pares e conselho editorial; d) Publicação periodicidade, tempo de publicação, pontualidade, distribuição; e) Aspectos econômicos. 


\section{A análise quantitativa}

Os artigos e as teses de livre-docência foram quantificados e categorizados como: a) Interdisciplinar, b) Não Interdisciplinar, c) Inserido no pensamento sistêmico e d) Não inserido no pensamento sistêmico.

A partir das categorias acima os artigos foram sub-categorizados quanto a: artigos originais, artigos de revisão (incluindo atualização e trabalhos especiais), comunicações (comunicações breves a respeito de metodologia ou resultados preliminares), notas ou ponto de vista.

Das revistas foram quantificados os seguintes itens:

a) as páginas (total de páginas por ano de cada revista e total de páginas dos artigos caracterizados pelo pensamento sistêmico);

b) o total de volumes, artigos publicados e artigos analisados por ano;

c) o total de artigos escritos exclusivamente por pesquisadores da ESALQ;

d) o total de autores procedentes da ESALQ (Professores e Alunos) e do CENA; consultores do IPEF e outros (Institutos, universidades nacionais e estrangeiras, empresas etc) e

e) as seções temáticas escolhidas pelos pesquisadores.

Também no referido período do estudo foram quantificadas através dos Currículos Lattes dos docentes da ESALQ, as demais revistas, visando identificar a porcentagem representativa das publicações dos periódicos do estudo ("Scientia Agricola" e "Scientia Forestalis"), dentre o conjunto das publicações dos docentes da ESALQ em periódicos científicos nacionais e internacionais. 


\section{RESULTADOS E DISCUSSÃO}

\subsection{Das revistas científicas}

Das revistas produzidas pela ESALQ foram selecionadas a "Scientia Agricola" (SA) e a "Scientia Forestalis" (SF), identificadas com as credenciais necessárias para inclusão nos critérios: título, periodicidade e acesso.

\subsubsection{Análise das características estruturais e administrativas das revistas científicas}

O período de existência ininterrupta que varia de 32 anos (1970) "Revista IPEF” (atual Scientia Forestalis) - a 58 anos (1944) - “Anais da Escola Superior Agrícola 'Luiz de Queiroz’” (atual Scientia Agricola) - comprova que essas revistas estão consolidadas e têm longevidade garantida pelo suporte recebido de instituições solidamente estabelecidas como o IPEF e a ESALQ. Essas entidades obedecem aos preceitos de normalização do registro International Standart Serial Number $^{12}$ - Número Internacional Normalizado para Publicações Seriadas (ISSN), estando presente em ambas as revistas e mantêm as periodicidades estipuladas. As duas revistas são filiadas à Associação Brasileira de Editores Científicos (ABEC).

12 O ISSN é o identificador aceito internacionalmente para individualizar o título de uma publicação seriada tornando-o único e definitivo. Ele identifica o título de uma publicação seriada (jornais, revistas, anuários etc) em circulação, futuras (pré-publicações) e encerradas em qualquer idioma ou suporte físico utilizado (impresso, "on line”, Cd-Rom etc). 
TABELA 1. Distribuição das revistas selecionadas segundo as características estruturais e administrativas de editoração (1998-2002)

\begin{tabular}{|c|c|c|c|c|c|}
\hline Títulos & $\begin{array}{l}\text { Data } \\
\text { Vol.1 }\end{array}$ & $\begin{array}{l}\text { Volume } \\
2002 \\
\end{array}$ & Periodicidade & ISSN & $\begin{array}{c}\text { Entidade } \\
\text { Responsável }\end{array}$ \\
\hline $\begin{array}{l}\text { Scientia } \\
\text { Agricola* }\end{array}$ & 1944 & 59 & Trimestral & $\begin{array}{l}0103- \\
9016\end{array}$ & ESALQ \\
\hline $\begin{array}{l}\text { Scientia } \\
\text { Forestalis** }\end{array}$ & 1970 & 62 & Semestral & $\begin{array}{l}1413- \\
9324\end{array}$ & $\begin{array}{c}\text { IPEF } \\
\text { ESALQ } \\
\text { (Departamento } \\
\text { de Ciências } \\
\text { Florestais) } \\
\end{array}$ \\
\hline
\end{tabular}

Quanto às fontes de informação secundárias representadas pelas Bases Latino-americanas e Internacionais observou-se que ambas estão indexadas na Chemical Internacional Abstracts (CABi) e somente a revista "SA" foi incorporada ao Scientific Eletronic Library Online (SciELO) - Apêndice 3. Sabe-se que quanto maior o número de bases nas quais a revista é indexada maior é seu poder de alcance. No período do referido estudo a revista "SF" estava como indexada apenas na base CABi, como pode ser observado na Tabela 2.

TABELA 2. Distribuição das revistas selecionadas segundo as características estruturais e administrativas de difusão e visibilidade (1998-2002)

\begin{tabular}{|c|c|c|c|c|c|}
\hline Títulos & Tiragem & $\begin{array}{c}\text { Distribuição } \\
\text { Circulação }\end{array}$ & Publicidade & $\begin{array}{c}\text { Apoio } \\
\text { Financeiro }\end{array}$ & $\begin{array}{c}\text { Acesso* } \\
\text { Indexação } \\
\text { em Fonte } \\
\text { secundária }\end{array}$ \\
\hline $\begin{array}{l}\text { Scientia } \\
\text { Agricola }\end{array}$ & $\begin{array}{l}\text { Não } \\
\text { consta }\end{array}$ & \begin{tabular}{l}
\multicolumn{2}{c}{ Assinatura } \\
Venda na \\
secretaria da \\
redação
\end{tabular} & $\begin{array}{c}\text { Não } \\
\text { apresenta } \\
\text { Exceção: } \\
\text { Páginas } \\
\text { prefaciais } \\
\text { v.59, nº4, } \\
\text { dez/2002 }\end{array}$ & FAPESP & $\begin{array}{l}\text { SciELO } \\
\text { Agris } \\
\text { Agrobase } \\
\text { CABi } \\
\text { INIS } \\
\text { Tropag Rural }\end{array}$ \\
\hline $\begin{array}{l}\text { Scientia } \\
\text { Forestalis }\end{array}$ & $\begin{array}{l}\text { Não } \\
\text { consta }\end{array}$ & $\begin{array}{l}\text { Sócios/ } \\
\text { Assinatura }\end{array}$ & $\begin{array}{c}\text { Não } \\
\text { apresenta }\end{array}$ & $\begin{array}{c}\text { Empresas } \\
\text { filiadas ao } \\
\text { IPEF }\end{array}$ & CABi \\
\hline
\end{tabular}




\section{A REVISTA CIENTÍFICA “SCIENTIA AGRICOLA”}

Em 1944 iniciou-se a publicação dos “Anais da Escola Superior Agrícola 'Luiz de Queiroz'” (Campus USP/Piracicaba-SP). Tratava-se de um periódico de edição anual com artigos de pesquisa da própria Instituição que contava com renomados professores. O título Anais foi escolhido uma vez que era composto por trabalhos apresentados em congressos; muitos dos trabalhos eram resumos que não tinham recebido a aprovação do conselho editorial (Reichardt, 1998, lv.). A partir de 1979 no volume 1 n.11 dos Anais, os trabalhos do Centro de Energia Nuclear na Agricultura (CENA) - Campus USP/Piracicaba-SP - passaram a ser incorporados.

Os Anais foram publicados até 1992, até o volume 48. A partir do volume 49, ainda em 1992, passou a ser denominado como "Revista Scientia Agricola”, um periódico institucional da USP que cobre a área de ciências agrárias. A principal justificativa para essa mudança foi:

"A intenção de perder o caráter endogâmico, característica dos Anais, e torná-la uma revista aberta às comunidades agronômicas, regionais, nacionais e internacionais. Além das mudanças estruturais que ocorreram ao passar dos anos, no ano de 2000 a revista surgiu como um novo modelo, obedecendo aos padrões das revistas de circulação internacional” (Reichardt, 2000, lv.).

"A importância dada para artigos publicados no exterior é um mito que precisa ser derrubado", segundo Reichardt (2000, lv.). As revistas nacionais tendem a ter seu prestígio abalado, uma vez que é dado maior peso pelos órgãos de fomento para trabalhos publicados no exterior. Para o autor citado, essa situação precisa ser reconsiderada:

"A meta da Scientia Agricola é estabelecer-se como uma revista nacional forte, com circulação internacional, procurando seu lugar dentro da comunidade agrícola mundial, sendo fundamental a colaboração dos usuários e leitores, uma vez que a equipe de editores está aberta para sugestões e mudanças, tornando-a cada vez mais adequada para seus fins" (Reichardt , 2000, lv.).

\section{a) Conteúdo - caráter científico}

O objetivo da "Scientia Agricola”, segundo a seção Instruções aos 
Autores, é o de publicar artigos originais elaborados por especialistas nacionais e estrangeiros que contribuam para o desenvolvimento científico das Ciências Agrárias. Também abrange as temáticas: Produção Vegetal, Produção Animal, Engenharia Rural, Economia e Sociologia, Tecnologia Agroindustrial, Ciências Florestais, Ciências Ambientais e do Solo e Ciências Básicas Aplicadas à Agricultura, conforme observamos na Tabela 3.

Segundo Reichardt (1992, lv.) “a Scientia Agricola é aberta a qualquer publicação original que contribua à ampliação de nossos conhecimentos nas ciências agrárias".

TABELA 3. Distribuição dos artigos publicados na revista "SA" segundo as seções temáticas (2000-2002)

\begin{tabular}{|c|c|c|c|c|}
\hline Seções & 2000 & 2001 & 2002 & Total \\
\hline Agrometeorologia & 02 & - & 02 & 04 \\
\hline Ciência Animal e Pastagens & 06 & 10 & 15 & 31 \\
\hline Engenharia Agrícola & 01 & 02 & 04 & 07 \\
\hline Entomologia & 06 & 09 & 12 & 27 \\
\hline $\begin{array}{l}\text { Fisiologia e Bioquímica das } \\
\text { Plantas }\end{array}$ & 13 & 11 & 10 & 34 \\
\hline Fitotecnia & 30 & 19 & 17 & 66 \\
\hline $\begin{array}{l}\text { Genética e Melhoramento de } \\
\text { Plantas }\end{array}$ & 08 & 11 & 08 & 27 \\
\hline Solos e Nutrição de Plantas & 20 & 31 & 26 & 77 \\
\hline Estatística & 02 & 01 & 02 & 05 \\
\hline $\begin{array}{llll}\text { Ciência e } & \text { Tecnologia } & \text { de } \\
\text { Alimentos } & & & \end{array}$ & 08 & 02 & 02 & 12 \\
\hline Fitopatologia & 02 & 03 & 01 & 06 \\
\hline Microbiologia Agrícola & 03 & 01 & - & 04 \\
\hline Ciências Florestais & 01 & - & - & 01 \\
\hline Economia Aplicada & - & 01 & 01 & 02 \\
\hline Notas & 26 & 18 & 16 & 60 \\
\hline Revisão & - & 02 & 04 & 06 \\
\hline Ponto de Vista & 01 & - & - & 01 \\
\hline TOTAL & 129 & 121 & 120 & 370 \\
\hline
\end{tabular}

Os anos de 1998 e 1999 não foram computados porque nesse período ainda não existiam as seções temáticas.

Pelos indicadores da Tabela 4 podemos observar as seções temáticas mais abordadas na revista "SA" durante o período de 2000 a 2002, bem como as seções que tiveram menos artigos publicados. 
TABELA 4. Classificação das seções temáticas mais e menos abordadas por todos os pesquisadores na revista "SA" (2000-2002)

\begin{tabular}{|c|c|c|c|c|}
\hline $\begin{array}{l}\text { Seções Mais } \\
\text { Abordadas }\end{array}$ & & $\begin{array}{l}\text { Total de } \\
\text { Artigos }\end{array}$ & $\begin{array}{l}\text { Seções Menos } \\
\text { Abordadas }\end{array}$ & $\begin{array}{l}\text { Total de } \\
\text { Artigos }\end{array}$ \\
\hline $\begin{array}{l}\text { Solos e Nutrição } \\
\text { Plantas }\end{array}$ & de & $77(20,8 \%)$ & Ciências Florestais & $1(0,2 \%)$ \\
\hline Fitotecnia & & $66(17,8 \%)$ & Economia Aplicada & $2(0,5 \%)$ \\
\hline $\begin{array}{l}\text { Fisiologia } \\
\text { Bioquímica }\end{array}$ & e & $34(9,1 \%)$ & Estatística & $3(0,8 \%)$ \\
\hline $\begin{array}{l}\text { Ciência Animal } \\
\text { Pastagens }\end{array}$ & e & $31(8,3 \%)$ & $\begin{array}{l}\text { Microbiologia } \\
\text { Agrícola }\end{array}$ & $4(1 \%)$ \\
\hline Entomologia & & $27(7,2 \%)$ & Agrometeorologia & $4(1 \%)$ \\
\hline TOTAL & & $235(63,2 \%)$ & $\begin{array}{l}\text { Estatística } \\
\text { TOTAL }\end{array}$ & $\begin{array}{r}5(1,35 \%) \\
19(4,85 \%) \\
\end{array}$ \\
\hline
\end{tabular}

Nota-se que, embora citadas no folder da revista, as temáticas Ciências Ambientais e Sociologia não configuraram em nenhuma das tabelas anteriores e estas temáticas são fundamentais para a formação ambiental fundamentada no novo paradigma.

\section{b) Estrutura dos Artigos}

Analisamos a estrutura, ou seja, a composição de 116 artigos (20\% do total) - artigos originais, revisão, notas e ponto de vista - equivalente a 21 volumes.

Os artigos originais estavam compostos por introdução, material e métodos, resultados e discussão, conclusões, agradecimentos e referências bibliográficas.

Os textos foram publicados em português ou em inglês; nos sumários constavam os títulos dos trabalhos em português e inglês e os nomes dos autores; as seções temáticas surgiram a partir de 2000 e as palavras-chave constavam em todos os artigos analisados em português e inglês, com seus respectivos resumos também em português e inglês.

\section{c) Gestão Editorial: abordagem de pares e conselho editorial}

O corpo editorial está vinculado à pós-graduação da ESALQ e aberto à comunidade científica nacional e internacional. $\mathrm{O}$ artigo primeiramente é encaminhado ao editor chefe para o seu parecer, depois é enviado aos dois pareceristas científicos. 
Estes, na maioria das vezes, reencaminham o artigo ao autor para correções, segundo a normatização da revista, e após retorno do artigo o mesmo é publicado. O tempo varia de acordo com cada etapa do processo.

O corpo editorial analisado por este estudo era composto por: 1 editorchefe (ESALQ), 1 editor-assistente (ESALQ), 4 editores-científicos (ESALQ/CENA), 21 editores associados: sendo 11 estrangeiros (United States of América (USA) $=5$, Inglaterra = 1, Espanha = 1, Alemanha = 1, França = 1, Alemanha = 1 e Áustria =1), 8 editores de universidades brasileiras (Universidade de São Paulo $=3$ : um destes é da USP e da Universidade de Mogi das Cruzes, Universidade Estadual Paulista $=1 \mathrm{e}$ Universidade Federal = 4), 1 editor da Empresa Brasileira de Pesquisa Agropecuária (Embrapa)/Londrina e 1 editor da Embrapa/Jaguariúna.

Para Luís Reynaldo Ferracciú Alleoni (2002, lv.), atual editor chefe da revista, "a política da Comissão Editorial da revista tem sido aumentar a avaliação externa dos artigos, minimizando o caráter endógeno que a revista teve por muito tempo". Ainda para esse autor, revisores de outros estados brasileiros e de outros países avaliaram esses artigos.

TABELA 5. Porcentagem de artigos da revista "SA" avaliados por revisores externos à ESALQ $(1997-2001)$

\begin{tabular}{cc}
\hline Anos & Porcentagem \\
\hline 2001 & $49 \%$ \\
2000 & $41 \%$ \\
1999 & $31 \%$ \\
1998 & $26 \%$ \\
1997 & $16 \%$ \\
\hline
\end{tabular}

\section{d) Publicação}

Quanto à periodicidade, nas bibliotecas da ESALQ estavam todos os volumes editados no período de 1944 a 2002. Os outros aspectos de publicação (periodicidade, tempo de publicação e distribuição) estão descritos nas Tabelas 1 e 2.

\section{e) Aspectos Econômicos}

A revista conta com auxílio à publicação da Fundação de Amparo à Pesquisa do Estado de São Paulo (FAPESP) e faz parte do Projeto SciELO, que é uma cooperação FAPESP/Centro Latino-Americano e do Caribe de Informação em Ciências da Saúde (BIREME) e Conselho Nacional de Desenvolvimento Científico e Tecnológico (CNPq) de Periódicos Eletrônicos . 


\section{A REVISTA CIENTÍFICA “SCIENTIA FORESTALIS”}

O IPEF criou em 1970 uma revista denominada “Revista IPEF”, que teve sua continuação sob esta denominação até o número 48/49. Desde 1970, a revista tem como objetivo publicar os trabalhos produzidos pelo convênio do IPEF com o Departamento de Ciências Florestais da ESALQ. Na década de 80, outras instituições ligadas ao setor florestal demonstraram interesse em publicar seus trabalhos na revista. A partir daí, a mesma perdeu o caráter institucional para se tornar uma revista destinada à sociedade florestal. Em 1996, a partir do número 50, a “Revista IPEF” passou a ser denominada de "Scientia Forestalis".

A revista "SF" apresenta artigos em inglês e em português, bem como resumos, cabeçalhos, tabelas e figuras, isto se justifica porque:

"A ciência sempre foi internacional na sua abrangência, mas o acelerado processo de globalização da sociedade atual exige que mesmo um periódico científico com características regionais participe do desenvolvimento científico internacional. Esse é um desafio que as Ciências Florestais brasileiras devem enfrentar" (Batista,1996, p.7).

\section{a) Conteúdo - caráter científico}

A revista "SF" tem como objetivo publicar trabalhos científicos inéditos relacionados às diversas áreas das Ciências Florestais. Artigos de pesquisas sobre a silvicultura, o manejo florestal, a conservação da natureza, os impactos ambientais em florestas, a tecnologia de madeiras, os produtos florestais e as áreas correlatas também podem ser submetidos à Comissão Editorial. Os assuntos tratados devem estar "diretamente relacionados às Ciências Florestais ou devem possuir clara implicação sobre o desenvolvimento científico e tecnológico no contexto florestal” (http://www.IPEF.br/publicações/scientia/sobre.html, 04 Jan. 2003).

Verificamos que a revista não possui seções temáticas e os artigos estavam dispostos no sumário, em seqüência. Pela análise dos textos dos artigos, os resultados obtidos indicaram que o referido periódico pertence ao núcleo de revistas especializadas na área florestal. 


\section{b) Estrutura dos Artigos}

Analisamos a estrutura, ou seja, a composição dos 20 artigos (20\% do total) - artigos originais e comunicações - equivalentes a 8 (oito) volumes.

Os artigos originais foram compostos por introdução, metodologia, resultados e discussão, conclusão e no fechamento do trabalho: referências bibliográficas, autores e agradecimentos. Os trabalhos de revisão e organização são mais livres, mas é necessário apresentar a referência completa do trabalho/livro que está sendo comentado.

Os textos foram publicados em português, embora a revista publique também em inglês; nos sumários constavam os títulos dos trabalhos em português e inglês e os nomes dos autores; não havia seções temáticas e as palavras-chave estavam em todos os artigos analisados em português e em inglês, com seus respectivos resumos também em português e em inglês.

\section{c) Gestão Editorial: abordagem de pares e conselho editorial}

O corpo editorial do último volume analisado, ou seja, de dezembro/2002 era composto por: 1 editora executiva (IPEF), 4 editores-científicos (ESALQ) e 31 editores associados: sendo 27 editores de universidades brasileiras (Universidade de São Paulo $=10$, Universidade Estadual Paulista $=4$, Universidades Federais $=9$ e Universidade de Brasília = 4), 2 editores da Embrapa Florestas, 1 do CENA e 1 editor do Instituto Florestal de São Paulo.

\section{d) Publicação}

Quanto à disponibilidade, na biblioteca central da ESALQ estavam todos os volumes editados no período de 1996 a 2002, os outros aspectos de publicação (periodicidade, tempo de publicação e distribuição) estão descritos nas Tabelas 1 e 2.

\section{e) Aspectos Econômicos}

A revista é publicada pelo IPEF em convênio com o Departamento de Ciências Florestais da ESALQ. O IPEF, na edição de dezembro/2002 contava com 15 sócios titulares (14 empresas nacionais e 1 do México), sendo a maioria desses sócios composta por empresas instaladas em diversos estados brasileiros atuantes no ramo de celulose e papel. 


\subsubsection{Análise quantitativa das revistas científicas}

\subsubsection{O universo da amostragem}

No período de 1998 a 2002 a revista "SA" apresentou um total de 638 itens incluindo: 548 artigos originais, 82 notas, 7 artigos de revisão e 1 artigo ponto de vista. Desse total, utilizamos uma amostragem de 20\%, ou seja, 127 itens. Como nossa análise de dados corresponde ao período já citado, de 5 anos, visando uma melhor distribuição e equivalência do total de artigos a serem analisados por ano, dividimos 127 artigos por 5 (anos), o que resultou em 25 artigos/ano; sendo a revista trimestral (quatro fascículos por ano), dividimos 25 por 4, resultando na análise de 6 artigos de cada fascículo. Assim, ao analisar os 6 artigos procuramos ainda selecionar somente os artigos escritos por pesquisadores da ESALQ e também selecionar os artigos inscritos em diversas temáticas da revista, evitando privilegiar uma determinada temática (ex. solo, fitotecnia, entomologia etc). Como somente a partir de 2000 foram implantadas as temáticas na revista "SA", fizemos o levantamento dos artigos dos anos de 1998 e 1999 a partir da leitura dos títulos e resumos dos mesmos.

Os artigos selecionados para análise foram escritos apenas por pesquisadores da ESALQ, entretanto ocorreu que 5 números ou exemplares da "SA" não apresentaram número suficiente de artigos escritos exclusivamente por pesquisadores da ESALQ para completar nossa amostragem de 6 artigos/ano. Faltaram assim 10 artigos, a saber: 2 artigos do $n^{\circ}$ especial/1998, 1 artigo do $n^{\circ} 4 / 1999,3$ artigos do $n^{0} 1 / 2002$, 2 artigos do $n^{0} 3 / 2002$ e 2 artigos do $n^{\circ} 4 / 2002$.

Para análise dos artigos da “SF”, utilizamos os mesmos critérios descritos anteriormente. No período de 1998 a 2002 a “SF” apresentou um total de 117 itens distribuídos em: 113 artigos originais e 4 comunicações. Deste total utilizamos uma amostragem de 20\%, ou seja, 23 itens. Estes 23 itens foram divididos por 5 anos, resultando em 4 artigos/ano. Como a revista é semestral (2 fascículos por ano) selecionamos 2 artigos por fascículo, visando assim, como na "SA", uma melhor distribuição e equivalência quanto ao total de artigos a serem analisados.

Em síntese, analisamos 116 artigos da revista "SA" e 20 artigos da revista "SF”, o que significa um total de 136 artigos analisados. 
TABELA 6. Levantamento dos fascículos, artigos publicados e artigos analisados da revista "SA", no período de 1998 a 2002

\begin{tabular}{cccc}
\hline Anos & $\begin{array}{c}\text { Total de } \\
\text { Fascículos }\end{array}$ & $\begin{array}{c}\text { Total de } \\
\text { Artigos* }\end{array}$ & $\begin{array}{c}\text { Total de } \\
\text { Artigos } \\
\text { Analisados }\end{array}$ \\
\hline 2002 & 04 & 120 & 17 \\
2001 & 04 & 121 & 24 \\
2000 & 04 & 129 & 24 \\
1999 & $05^{* *}$ & 170 & 29 \\
1998 & 04 & 98 & 22 \\
TOTAL & $\mathbf{2 1}$ & $\mathbf{6 3 8}$ & $\mathbf{1 1 6}$
\end{tabular}

*Inclusos artigos originais, revisão, notas e ponto de vista.

**Além dos quatros volumes houve a publicação de um suplemento especial.

TABELA 7. Levantamento dos fascículos, artigos publicados e artigos analisados da revista "SF", no período de 1998 a 2002

\begin{tabular}{cccc}
\hline Anos & $\begin{array}{c}\text { Total de } \\
\text { Fascículos }\end{array}$ & $\begin{array}{c}\text { Total de } \\
\text { Artigos* }\end{array}$ & $\begin{array}{c}\text { Total de } \\
\text { Artigos } \\
\text { Analisados }\end{array}$ \\
\hline 2002 & 02 & 25 & 04 \\
2001 & 02 & 24 & 04 \\
2000 & 02 & 24 & 04 \\
1999 & 02 & 24 & 04 \\
1998 & 02 & 20 & 04 \\
TOTAL & $\mathbf{1 0}$ & $\mathbf{1 1 7}$ & $\mathbf{2 0}$ \\
\hline
\end{tabular}

*Inclusos artigos originais e comunicações.

Em ambas as revistas, notamos um crescimento do número de artigos publicados em 1999 em relação a 1998, e posteriormente houve uma certa estabilidade com pequena oscilação no número de artigos.

Quanto às demais revistas, ressaltamos que a ESALQ possui 11 departamentos e 225 docentes: de cada departamento utilizamos uma amostragem de 20\%, ou seja, no total foram analisados os Currículos Lattes de 45 docentes, sorteados aleatoriamente por departamento.

Dessa forma, procuramos a partir dessa quantificação identificar a 
quantidade, ou seja, o percentual das revistas analisadas neste estudo (“Scientia Agricola” e "Scientia Forestalis") dentre o conjunto de publicações dos docentes da Instituição nos periódicos nacionais e internacionais.

TABELA 8. Percentual das revistas "SA" e "SF" em relação ao conjunto de publicações extraídas de 20\% dos Currículos Lattes dos docentes da ESALQ, no período de 1998 a 2002

\begin{tabular}{lcc}
\hline \multicolumn{1}{c}{ Periódicos } & N $^{\text {o }}$ de artigos publicados & Percentual \\
\hline Scientia Agricola & 82 & 17,33 \\
Scientia Forestalis & 32 & 6,76 \\
Revistas Nacionais & 314 & 66,38 \\
Revistas Internacionais & 45 & 9,51 \\
TOTAL & $\mathbf{4 7 3}$ & $\mathbf{1 0 0}$ \\
\hline
\end{tabular}

Pelos valores destacados na tabela acima pode-se notar que a revista "SA" configurou-se com maior representatividade de artigos publicados em relação às revistas internacionais. As diversas seções temáticas que a revista "SA" apresenta, bem como o seu caráter científico (vide Tabelas 3 e 4) e seu longo tempo de existência (vide Tabela 1), podem ser considerados fatores atrativos para que os pesquisadores da Instituição e de diferentes áreas de conhecimento venham a publicar artigos nessa revista. Ao contrário da revista “SF”, que não possui seções temáticas, tem caráter científico mais restrito à área florestal, configurando-se com 6,76\% em relação ao total.

\subsubsection{Quantificação das revistas científicas “SA" e "SF" quanto à paginação e procedência dos autores (relação autor/artigo e autor/seções temáticas)}

Os 21 fascículos analisados da revista "SA" correspondem a 4444 páginas publicadas no período de 1998 a 2002. Dessas, analisamos 790 páginas (116 artigos). No mesmo período, os 10 fascículos da revista “SF” totalizaram 2221 páginas e destas, analisamos 215 páginas (20 artigos). 
TABELA 9. Total de páginas analisadas referentes aos artigos publicados na revista "SA" no período de 1998 a 2002

\begin{tabular}{ccc}
\hline Anos & Total de Páginas & Total de Artigos \\
\hline 2002 & 106 & 17 \\
2001 & 156 & 24 \\
2000 & 160 & 24 \\
1999 & 219 & 29 \\
1998 & 149 & 22 \\
TOTAL & $\mathbf{7 9 0}$ & $\mathbf{1 1 6}$
\end{tabular}

O fascículo n56 do ano de 1999 da revista "SA" foi o que mais continha páginas, num total de 1290 e o que continha menor número foi o fascículo n55 de 1998, com 675 páginas.

TABELA 10. Total de páginas analisadas referentes aos artigos publicados na revista "SF" no período de 1998 a 2002

\begin{tabular}{ccc}
\hline Anos & Total de Páginas & Total de Artigos \\
\hline 2002 & 55 & 04 \\
2001 & 35 & 04 \\
2000 & 54 & 04 \\
1999 & 35 & 04 \\
1998 & 36 & 04 \\
TOTAL & $\mathbf{2 1 5}$ & $\mathbf{2 0}$ \\
\hline
\end{tabular}

Na revista "SF" os volumes n ${ }^{\circ} 57$ e n ${ }^{\circ} 58$ do ano de 2000, continham o maior número de páginas, 344; e os fascículos nº53 e nº54, de 1998, os de menor número de páginas, 248. Notamos que em termos de total de páginas, ambas as revistas apresentaram um aumento, a partir de 1998.

Quanto à procedência dos autores, conforme demonstramos na Tabela 11, durante todo o período (1998 a 2002) houve um aumento do número de autores de outras instituições e no período de 2000 a 2002 houve um decréscimo dos autores da ESALQ. Isso confirma que a revista “SA" não possui caráter endógeno, e sim 
multiinstitucional, embora em algumas seções temáticas autores procedentes da ESALQ tenham sido maioria (Tabela 14).

Ressaltamos também, que na revista "SA", o número de autores por artigo varia de 1 a 10, e da revista "SF" de 1 a 7. Notamos também em alguns artigos, têm autoria conjunta de profissionais da ESALQ com pesquisadores de outras instituições, ou escritos somente por autores de outras instituições ou aqueles escritos somente por autores da ESALQ.

TABELA 11. Identificação da procedência dos autores que publicaram artigos na revista "SA" (1998-2002)

\begin{tabular}{|c|c|c|c|c|c|c|c|c|c|c|c|c|}
\hline \multirow{2}{*}{$\begin{array}{l}\text { Ano } / \mathrm{N}^{\circ} \text { autores } \\
\text { Procedência }\end{array}$} & \multicolumn{2}{|c|}{1998} & \multicolumn{2}{|c|}{1999} & \multicolumn{2}{|c|}{2000} & \multicolumn{2}{|c|}{2001} & \multicolumn{2}{|c|}{2002} & \multicolumn{2}{|c|}{ TOTAL } \\
\hline & $\mathbf{N}^{\circ}$ & $\%$ & $\mathbf{N}^{\circ}$ & $\%$ & $\mathbf{N}^{\circ}$ & $\%$ & $\mathbf{N}^{0}$ & $\%$ & $\mathbf{N}^{\mathbf{o}}$ & $\%$ & $\mathbf{N}^{\circ}$ & $\%$ \\
\hline ESALQ & 119 & 43,7 & 262 & 45 & 174 & 40,7 & 155 & 37,8 & 113 & 27,4 & 823 & 39,1 \\
\hline CENA & 9 & 3,3 & 47 & 8 & 30 & 7 & 16 & 3,9 & 26 & 6,3 & 128 & 6 \\
\hline OUTROS & 144 & 52,9 & 272 & 46,8 & 223 & 52,2 & 238 & 58,1 & 272 & 66 & 1149 & 54,7 \\
\hline SUB TOTAL & 272 & & 581 & & 427 & & 409 & & 411 & & & \\
\hline
\end{tabular}

TABELA 12. Identificação do número total de autores* por número de artigos publicados na revista "SA" $(1998$ - 2002)

\begin{tabular}{cccccc}
\hline \multirow{2}{*}{ Números dos Fascículos } & \multicolumn{5}{c}{$\mathrm{N}^{\mathrm{o}}$ autores/No artigos } \\
& 1998 & 1999 & 2000 & 2001 & 2002 \\
\hline 01 & $17 / 7$ & $24 / 8$ & $19 / 6$ & $22 / 6$ & $10 / 3$ \\
02 & $17 / 6$ & $34 / 10$ & $29 / 11$ & $26 / 8$ & $25 / 10$ \\
03 & $29 / 9$ & $32 / 8$ & $20 / 7$ & $21 / 6$ & $13 / 4$ \\
04 & - & $29 / 7$ & $44 / 14$ & $35 / 9$ & $10 / 4$ \\
04 Especial & $5 / 4$ & $37 / 11$ & - & - & - \\
SUB TOTAL & $68 / 26$ & $156 / 44$ & $112 / 38$ & $104 / 29$ & $58 / 21$ \\
TOTAL & & & $\mathbf{4 9 8 / 1 5 8}$ & & \\
\hline
\end{tabular}

*Exclusivos da ESALQ.

Na Tabela 12 estão quantificados todos os artigos escritos por pesquisadores da ESALQ, ou seja, os dados não se referem apenas aos artigos selecionados para análise deste trabalho. Conforme descrito na tabela, o número de 
autores total, bem como o número de artigos vem diminuindo a partir de 1999.

No número especial de 1998 da revista "SA" foi registrado o menor número de autor/artigo e todos os artigos foram escritos em inglês. Ocorreu que os pesquisadores da ESALQ publicaram mais artigos em parceria com outros pesquisadores. Já o n44, de 2000, contou com o maior número de autores por artigo.

Na revista "SA" de 1998 e 1999 os autores eram identificados pelas iniciais do nome e sobrenome completo, a partir de 2000, excluem-se as iniciais e passam a ser publicados os nomes completos, sem abreviaturas.

Segundo o atual editor-chefe da revista:

"No Brasil as revistas científicas são, classicamente, divididas em duas categorias: as institucionais (públicas e privadas) e as ligadas à Sociedade Científica. Durante muito tempo, afirma o editor, as revistas institucionais tiveram como objetivo a publicação de artigos da entidade mantenedora, a fim de que os resultados da pesquisa da Instituição pudessem ser de conhecimento público” (Alleoni, 2002, p.1).

O editor ressalta que em alguns casos, era proibida a publicação de trabalhos de outras instituições e que nos últimos anos, essa tendência se inverteu de maneira acentuada em várias revistas.

"O caráter multiinstitucional dos artigos publicados é, hoje em dia, ponto decisivo para atestar as qualidades das revistas, e a Scientia Agricola tem procurado se adequar a esse novo modelo (...) Os autores de outras instituições representam nos artigos publicados atualmente uma porcentagem de 69\%, destes, 34\% são de autores externos com parcerias da ESALQ e/ou CENA, os 35\% restantes são de autores externos sem parcerias com a ESALQ e/ou CENA" (Alleoni, 2002, p.1). 
TABELA 13. Identificação das seções temáticas da revista "SA" em que prevaleceram autores procedentes da ESALQ (2000-2002)

\begin{tabular}{|c|c|c|c|c|c|c|c|c|c|}
\hline Número de aut & ores & & 00 & & 01 & & 02 & & \\
\hline Seções Temáticas & & ESALQ & Outros & ESALQ & Outros & ESALQ & Outros & ESAL & Outros \\
\hline $\begin{array}{l}\text { Ciência Animal } \\
\text { Pastagem }\end{array}$ & e & 22 & 11 & 44 & 11 & - & - & 66 & 22 \\
\hline Fitotecnia & & 52 & 45 & - & - & - & - & 52 & 45 \\
\hline $\begin{array}{l}\text { Genética } \\
\text { Melhoramento } \\
\text { Plantas }\end{array}$ & $\begin{array}{l}\mathrm{e} \\
\mathrm{de}\end{array}$ & 17 & 10 & - & - & 18 & 13 & 35 & 23 \\
\hline Entomologia & & - & - & 11 & 9 & - & - & 11 & 9 \\
\hline Agrometeorologia & & 5 & 2 & - & - & - & - & 5 & 2 \\
\hline Economia Aplicada & & - & - & - & - & 2 & - & 2 & 0 \\
\hline
\end{tabular}

*Em 1998 e 1999 a revista não possuía seções temáticas.

TABELA 14. Identificação das seções temáticas da revista "SA" em que prevaleceram autores procedentes de outras instituições (2000-2002)

\begin{tabular}{lcccccccc}
\multicolumn{1}{c}{ Número de autores } & \multicolumn{2}{c}{2000} & \multicolumn{2}{c}{2001} & \multicolumn{2}{c}{2002} & \multicolumn{2}{c}{ TOTAL } \\
Seções Temáticas & ESALQ & Outros & ESALQ & Outros & ESALQ & Outros & ESALQ & Outros \\
\hline $\begin{array}{l}\text { Solos e Nutrição de } \\
\text { Plantas }\end{array}$ & 19 & 30 & 19 & 85 & 12 & 76 & 50 & 191 \\
Fitotecnia & - & - & 16 & 45 & 14 & 50 & 30 & 95 \\
$\begin{array}{l}\text { Fisiologia e } \\
\text { Bioquímica }\end{array}$ & 11 & 30 & 8 & 22 & - & - & 19 & 52 \\
$\begin{array}{l}\text { Ciência Animal e } \\
\text { Pastagem }\end{array}$ & - & - & - & - & 21 & 40 & 21 & 40 \\
Entomologia & 11 & 13 & - & - & 7 & 25 & 18 & 38 \\
\hline
\end{tabular}

As seções temáticas descritas na tabela anterior foram as que contaram com o maior número de artigos; conforme veremos em tabela mais adiante, isso significa que a maioria dos artigos da revista "SA" foram escritos por autores de outras instituições. 
TABELA 15. Resultados comparativos das seções temáticas da revista "SA" escolhidas pelos pesquisadores da ESALQ ou de outras instituições (2000-2002)

\begin{tabular}{lcc}
\hline \multicolumn{1}{c}{ Seções Temáticas } & $\begin{array}{c}\text { Pesquisadores } \\
\text { da ESALQ }\end{array}$ & $\begin{array}{c}\text { Pesquisadores de } \\
\text { Outras } \\
\text { Instituições }\end{array}$ \\
\hline Solos e Nutrição de Plantas & 50 & 191 \\
Fitotecnia & 82 & 140 \\
Ciência Animal e Pastagem & 87 & 62 \\
Entomologia & 19 & 52 \\
Genética e Melhoramento de & 29 & 47 \\
Plantas & & \\
Agrometeorologia & 05 & 02 \\
Economia & 02 & - \\
\hline
\end{tabular}

As temáticas Solos e Nutrição de Plantas da revista "SA" foram as seções preferidas por pesquisadores de outras instituições, seguida por Fitotecnia. Já os pesquisadores da ESALQ configuram em maior número na seção de Ciência Animal e Pastagem, seguida das seções Fitotecnia e Solos, bem mais distantes, e finalmente Genética, Agrometeorologia e Economia.

A revista "SF" não possui seções temáticas. Logo, realizamos o levantamento geral da procedência dos autores, considerando o "IPEF” como órgão consultor do instituto. Notamos que embora a maioria dos autores fossem procedentes de outras instituições, a diferença percentual total foi pequena, sendo 40,4\% da ESALQ e $57,5 \%$ Outros (Tabela 16).

TABELA 16. Identificação da procedência dos autores que publicaram artigos na revista "SF" (1998-2002)

\begin{tabular}{|c|c|c|c|c|c|c|c|c|c|c|c|c|}
\hline \multirow{2}{*}{$\begin{array}{l}\text { Ano } / \mathrm{N}^{\circ} \text { autores } \\
\text { Procedência }\end{array}$} & \multicolumn{2}{|c|}{1998} & \multicolumn{2}{|c|}{1999} & \multicolumn{2}{|c|}{2000} & \multicolumn{2}{|c|}{2001} & \multicolumn{2}{|c|}{2002} & \multicolumn{2}{|c|}{ TOTAL } \\
\hline & $\mathrm{N}^{\circ}$ & $\%$ & $\mathrm{~N}^{\mathrm{o}}$ & $\%$ & $\mathrm{~N}^{\circ}$ & $\%$ & $\mathrm{~N}^{\circ}$ & $\%$ & $\mathrm{~N}^{\circ}$ & $\%$ & $\mathrm{~N}^{\circ}$ & $\%$ \\
\hline ESALQ & 24 & 39,3 & 30 & 47,6 & 31 & 46,2 & 29 & 38,1 & 28 & 31,3 & 142 & 40,4 \\
\hline CENA & - & - & - & - & 1 & 1,49 & 1 & 1,3 & - & - & 2 & 0,5 \\
\hline IPEF & 1 & 1,6 & 1 & 1,5 & 2 & 2,98 & 1 & 1,3 & - & - & 5 & 1,4 \\
\hline OUTROS & 36 & 59 & 32 & 50,7 & 33 & 49,2 & 45 & 59,2 & 56 & 66,6 & 202 & 57,5 \\
\hline SUB TOTAL & 61 & & 63 & & 67 & & 76 & & 84 & & & 51 \\
\hline
\end{tabular}


TABELA 17. Identificação do número total de autores* por número de artigos publicados na revista "SF" (1998 - 2002)

\begin{tabular}{cccccc} 
Período & \multicolumn{5}{c}{$\mathrm{N}^{\mathrm{o}}$ autores/ $\mathrm{N}^{\mathrm{o}}$ artigos } \\
& 1998 & 1999 & 2000 & 2001 & 2002 \\
\hline Junho & $7 / 3$ & $3 / 1$ & $7 / 3$ & $10 / 4$ & $6 / 2$ \\
Dezembro & $11 / 4$ & $9 / 4$ & $11 / 5$ & $14 / 6$ & $6 / 3$ \\
SUB TOTAL & $18 / 7$ & $12 / 5$ & $18 / 8$ & $24 / 10$ & $12 / 5$ \\
TOTAL & & & $\mathbf{8 4} / 35$ & & \\
\hline
\end{tabular}

*Exclusivos da ESALQ.

No ano de 2002, houve uma redução de 50\% tanto de autores como de artigos, em relação a 2001: o fascículo de dezembro/2001 continha o maior número de autores da ESALQ (14) e artigos (6), lembrando que cada fascículo tinha uma média de 11 a 12 artigos. No entanto, o exemplar de junho/99 foi o que contou com menos autores (3) e artigos (1).

\subsubsection{Quantificação e classificação dos artigos das revistas científicas "SA" e "SF" quanto às abordagens temáticas}

Os artigos foram quantificados e categorizados conforme os quesitos mencionados na metodologia. Assim, os artigos cujas pesquisas contemplaram os 7 aspectos do pensamento sistêmico configuraram um total de 6, os quais também foram considerados interdisciplinares. Logo, os seis artigos aliados ao pensamento sistêmico pertencem aos seguintes fascículos: um da revista "SA" n³/99 com 9 páginas e cinco da revista "SF". Esses cinco artigos da revista "SF" estavam distribuídos da seguinte forma: 2 artigos $\left(n^{0} 54 / 98\right)$ com 22 páginas, 1 artigo $\left(n^{\circ} 55 / 99\right)$ com 10 páginas e 2 artigos (n56/2001) com 20 páginas, totalizando 52 páginas. Os demais artigos que não continham as abordagens voltadas ao pensamento sistêmico, que foram 130, estava, distribuídos em artigos originais, revisão, notas, comunicação e ponto de vista de ambas as revistas. Ainda, dos 136 artigos, seis foram considerados interdisciplinares, conforme já mencionado, e 130 não interdisciplinares. 
TABELA 18. Classificação e quantificação das categorias quanto aos conteúdos dos artigos das revistas "SA" e "SF", no período de 1998 a 2002

\begin{tabular}{ccccc}
\hline Revistas & Categorias & \multicolumn{2}{c}{ Pensamento Sistêmico } & \multicolumn{2}{c}{ Interdisciplinar } \\
\hline & SIM & NÃO & SIM & NÃO \\
"SA" & 01 & 115 & 01 & 115 \\
"SF" & 05 & 15 & 05 & 15 \\
TOTAL & $\mathbf{0 6}$ & $\mathbf{1 3 0}$ & $\mathbf{0 6}$ & $\mathbf{1 3 0}$ \\
\end{tabular}

\subsection{Quantificação e classificação das teses de livre-docência quanto às abordagens temáticas}

No período de 1998 a 2002 foram defendidas 40 teses de livredocência na ESALQ. Assim, analisamos todas as 40 teses, que totalizaram 5611 páginas, das quais duas (5\%), que somam 278 páginas, foram consideradas aliadas ao pensamento sistêmico por conter os sete aspectos do referido pensamento, conforme mencionado na Revisão de Literatura. As 38 teses restantes (95\%) estavam voltadas à fragmentação do conhecimento.

TABELA 19. Classificação e quantificação das categorias quanto aos conteúdos das teses de livre-docência defendidas na ESALQ, no período de 1998 a 2002

\begin{tabular}{cccccc}
\hline \multirow{2}{*}{ Teses } & Categorias & \multicolumn{2}{c}{ Pensamento Sistêmico } & \multicolumn{2}{c}{ Interdisciplinar } \\
\hline \multirow{2}{*}{ TOTAL } & SIM & NÃO & SIM & NÃO \\
& & $\mathbf{0 2 *}$ & $\mathbf{3 8}$ & $\mathbf{0 3 * *}$ & $\mathbf{3 7}$ \\
\hline
\end{tabular}

\footnotetext{
* Teses $\mathrm{n}^{0} 34$ e $\mathrm{n}^{0} 38$

**Teses $n^{\circ} 15, n^{\circ} 34$ e ${ }^{\circ} 38$
}

\subsection{Análise qualitativa das teses de livre-docência e das revistas científicas}

Quanto às abordagens dos artigos das publicações "SA" e "SF" como das teses de livre-docência, algumas dificuldades foram encontradas pois nem sempre nos textos estavam explícitas as questões ambientais, além de os títulos apresentarem uma linguagem científica bastante específica. 
Através da utilização dos parâmetros de análise para caracterização dos conteúdos descritos na Metodologia, das 40 teses de livre-docência analisadas, a interdisciplinaridade estava presente em $3(7,5 \%)$ pois os autores mencionam os grupos participantes da pesquisa, formados por pesquisadores de diversas áreas e também por pessoas externas à comunidade científica. Isso não foi verificado nas outras 37 teses (92,5\%). A Tese $n^{\circ} 15$ contou com a colaboração de uma equipe interdisciplinar, mas os problemas ambientais apresentados na pesquisa não foram tratados a partir da abordagem do pensamento sistêmico.

A conexão entre o social e o natural, na maioria dos artigos como nas teses de livre-docência, limitou-se ao propósito de internalizar normas ecológicas e tecnológicas para restauração do ambiente, deixando à margem a análise do conflito social da realidade brasileira e até mesmo o terreno estratégico político que atravessa o campo ambiental.

Os aspectos que envolvem o ser humano são abordados principalmente nas teses que apontaram o homem como causador dos problemas ambientais (por exemplo: como causador dos incêndios, erosão, desmatamento etc). Uma vez relatadas as causas, foram justificados os meios para a restauração do ambiente. Ou seja, nas medidas propostas (reflorestamento de áreas urbanas e rurais, manejo de solo etc) o homem local não foi considerado como agente das ações propostas nem também não foram seus efeitos sobre o homem mesmo. Dessa abordagem, emerge a questão: passado algum tempo esse ambiente continuará restaurado? Pode ser que sim, mas é mais provável que não, pois as teses não apresentaram dados, troca de informações, de saberes, estratégias e planejamentos que envolvessem a comunidade, o ser humano.

Nesse contexto cabe a tão famosa fórmula de Pascal insistentemente citada em várias obras de Morin:

"Sendo todas as coisas causadas e causadoras, ajudadas $e$ ajudantes, que interligam as mais distantes e as mais diferentes, considero impossível conhecer as partes sem conhecer o todo, assim como conhecer o todo sem conhecer particularmente as partes" (Morin, 2002a, p.25).

É importante chamar a atenção para a palavra particularmente, que não 
é sinônima de parcialmente, ou seja, o particular no texto citado refere-se à busca pelo essencial.

$\mathrm{Na}$ perspectiva a partir da qual as teses explicavam as causas dos processos observáveis na realidade, como o desmatamento, a erosão etc, não foram oferecidas alternativas que contassem com estratégias para reformular os valores, os saberes, os conhecimentos e os paradigmas científicos.

A partilha de saberes, por meio do envolvimento da comunidade, envolve uma série de aspectos como: culturais, sociais, econômicos, entre outros, que são interdependentes do contexto ambiental e são fundamentais para o entendimento da problemática ambiental.

"É importante testar a viabilidade de alternativas de recuperação de fragmentos que apresentem um baixo custo de implantação, e se adequem às condições sócio-econômicas, culturais e ambientais locais (...) É fundamental envolver ao mínimo, os agricultores $e$ trabalhadores rurais nas atividades de recuperação de cobertura florestal. Essas pessoas são profundos conhecedores da realidade local e têm interesses diferenciados com relação às florestas” (Viana, 2002, p.30).

Portanto, questionamos na análise de conteúdo quais os objetivos das teses e dos artigos a que se visava e quais os resultados alcançados em relação aos aspectos mencionados acima, uma vez que fazem parte do contexto do pensamento sistêmico e interdisciplinar. Esses aspectos não foram encontrados nas 38 teses e nos 130 artigos. O que ocorreu foram resultados de ações pontuais (reflorestamento, manejo do solo, plantio baseado em determinado modelo, a resistência de plantas daninhas aos herbicidas etc) ocultando-se as inter-relações do processo como um todo. Logo, a questão ambiental acaba não sendo concebida como uma problemática de caráter eminentemente social, generalizada, de alcance planetário, mas sim fragmentada (Leff, 2002, p.111).

Em outras palavras, durante a leitura das teses e dos artigos, pudemos observar que a maioria das publicações e das teses desenvolvidas pela ESALQ foram elaboradas com eficiência, do ponto de vista cartesiano, pois estão completamente desconectadas da realidade complexa. 
Em síntese, as publicações "SA" e "SF" e as teses de livre-docência limitaram-se a levantar dados específicos, sendo incapazes de instigar o pensar sobre os problemas sociais e humanos envolvidos nas questões ambientais. Quando mencionado, o Social aparece absorvido por visões biologistas; não se chega à raiz dos problemas ambientais. Conforme mencionamos na Revisão de Literatura, a maioria dos problemas ambientais têm suas raízes em fatores sociais, econômicos e culturais e tornou-se visível que as pesquisas minimizaram ou reduziram a especificidade dos processos sociais em suas análises. Esse diagnóstico é bastante semelhante à observação de Leff:

\begin{abstract}
"Muitas pesquisas sobre mudanças ambientais minimizam ou reduzem a especificidade dos processos sociais em suas análises. A conexão entre o social e o natural limitou-se ao propósito de internalizar normas ecológicas e tecnológicas às teorias e às políticas econômicas, deixando à margem a análise do conflito social e o terreno estratégico do político que atravessam o campo ambiental” (Leff, 2002, p.111).
\end{abstract}

Apesar de as revistas "SA" e "SF" possuírem um corpo editorial diversificado, com pesquisadores de diferentes instituições e países, observamos no presente estudo que as mesmas não apresentaram a difusão das pesquisas ambientais de caráter interdisciplinar, aliás, esse perfil estava ausente na maioria dos artigos de ambas as revistas.

Além disso, é importante ressaltar que as próprias seções da revista "SA", intituladas de Ciências Ambientais e Sociologia, não contaram com nenhum artigo durante o período deste estudo.

Os fatos mencionados anteriormente, provenientes das observações das análises deste estudo, nos levaram a alguns questionamentos, resultando na abertura de caminhos para futuros estudos, os quais poderão vir a contribuir para os rumos da difusão das pesquisas ambientais desenvolvidas na ESALQ, lembrando que a publicação das pesquisas é um importante quesito para a avaliação tanto dos cursos de graduação (Engenharia Agronômica, Florestal, Gestão Ambiental entre outros) e pósgraduação (Recursos Florestais, Ecologia de Agroecossistemas entre outros) como do próprio corpo docente da Instituição:

1) Quais são as políticas adotadas pela Instituição para difusão das pesquisas, 
principalmente para as pesquisas ambientais de caráter interdisciplinar (como exemplo: as pesquisas desenvolvidas pelo Programa de Pós-Graduação Interunidades ESALQ/CENA em Ecologia de Agroecossistemas)?

2) Qual o posicionamento que a pesquisa ambiental da Instituição ocupa no conjunto das outras atividades e quais as condições para o seu funcionamento?

3) A maior parte das publicações das pesquisas ambientais da Instituição se dá ocorre na comunidade científica ou entre os diferentes segmentos da sociedade (produtores rurais, professores da rede de ensino de diversas esferas, população em geral etc)?

4) Além das revistas "SA" e "SF" quais os periódicos eleitos pelos pesquisadores da Instituição para divulgação de suas pesquisas? Quais os veículos utilizados? Como se dá esta veiculação?

Em relação aos periódicos interdisciplinares no campo ambiental, a discussão é considerada nova dentro do cenário de publicações e há inúmeros questionamentos. A seguir, citamos alguns:

1) Quais são os periódicos científicos que veiculam pesquisas interdisciplinares no campo ambiental?

2) Como se dá a avaliação de um periódico de caráter interdisciplinar?

3) Os periódicos de caráter interdisciplinar possuem o mesmo valor para os autores que para os das revistas disciplinares, considerando que o tempo exigido para o desenvolvimento de uma pesquisa desse caráter é maior que o de uma pesquisa de caráter unidisciplinar? Além de exigir uma integração da escrita para a elaboração do texto redigido, entre outros fatores?

Segundo Zanoni (2000, p.129) a definição de formas de valorização dos resultados produzidos pela pesquisa de caráter interdisciplinar "não encontra unanimidade entre os pesquisadores", o que vem a ser um outro questionamento a ser feito aos pesquisadores e órgãos ligados à pesquisa da Instituição. 


\section{CONCLUSÕES E CONSIDERAÇÕES FINAIS}

"Talvez haja outros conhecimentos a adquirir, outras interrogações a fazer hoje, partindo não do que outros souberam, mas do que eles ignoraram" (Serge Moscovici, 1960).

Pelo presente estudo concluímos que:

- Os periódicos científicos “Scientia Agricola” e “Scientia

Forestalis” seguem linhas temáticas nas quais os artigos não apresentam em seus conteúdos uma análise ambiental com visão sistêmica ou complexa;

- As pesquisas publicadas nos periódicos “Scientia Agricola” e “Scientia Forestalis” e nas teses de livre-docência da ESALQ não possuem uma dimensão ambiental em bases conceituais integradas e interdisciplinares, havendo uma forte tendência à fragmentação cartesiana dos temas e à dissociação entre homem/natureza. Assim, a interdisciplinaridade na produção do conhecimento ainda representa, na produção científica analisada da ESALQ, um desafio a ser enfrentado, com obstáculos epistemológicos, metodológicos e institucionais.

Desse modo, concluímos que as pesquisas publicadas nos periódicos “SA" e "SF" e nas teses de livre-docência da ESALQ, analisadas pelos indicadores empregados neste estudo, encontram-se amplamente defasadas em relação à incorporação do pensamento sistêmico e dos desdobramentos e superações que esse pensamento sofreu nos últimos cinqüenta anos. O pensamento sistêmico e seus desdobramentos são elementos fundamentais para o entendimento apropriado da realidade e as repercussões da ausência desse pensamento são difíceis de ser avaliadas, mas os danos têm enormes proporções, afetando não apenas a capacidade crítica dos pesquisadores, mas também o ensino que a Instituição oferece a seus alunos. 
Não podemos ignorar o fato de que:

"Um pensamento que não inclui a relação profunda e íntima com o meio ambiente, que não inclui a relação entre as partes e o todo, que se não for transformado, está condenado à mediocridade, à trivialidade, ao erro (...)" (Morin, 1996, p.193).

Entretanto, é importante ressaltar que este trabalho não teve a intenção de desmerecer os periódicos científicos analisados, os quais observarmos que possuem prestígio através das suas consolidadas existências, com periodicidades ininterruptas, corpos editoriais compostos por renomados profissionais de diversas áreas e de instituições nacionais e internacionais, obtendo, ambos, da Coordenadoria de Assistência à Pesquisa e Ensino Superior (CAPES), conceito A. Enfim, destacam-se como importantes veículos de disseminação do conhecimento científico agrário e florestal.

Pelo contrário, esperamos que este estudo, na medida do possível, venha a fornecer ao corpo editorial dos periódicos em estudo, subsídios à reflexão, assim como para os pesquisadores da ESALQ que publicam nesses periódicos e demais membros da Instituição.

A integração interdisciplinar de especialidades diversas e de um conjunto de saberes existentes em torno de um objeto de estudo e de uma problemática comum implica principalmente na integração de processos naturais e sociais de diferentes ordens e esferas de racionalidade. O processo de maturação de uma equipe interdisciplinar é lento, sua relação depende da escolha de um paradigma e de uma estratégia. Assim, reconhecemos que há outros paradigmas e não pretendemos com o presente estudo, afirmar que o paradigma do pensamento sistêmico seja o mais apropriado e que apresentará soluções para toda a problemática ambiental, principalmente por meio da educação. Outrossim, ele é um importante instrumento auxiliar na compreensão do pensamento ainda hegemônico, como esclarece Morin no texto a seguir:

"Trata-se de entender o pensamento que separa e que reduz, no lugar do pensamento que distingue e une. Não se trata de abandonar o conhecimento das partes pelo conhecimento das 
totalidades, nem da análise pela síntese; é preciso conjugá-las” (Morin, 2002d, p.46).

Enfim, devemos considerar a complexidade da problemática ambiental como um desafio e como uma motivação para a comunidade científica experimentar novas formas de pensar e produzir ciência.

Apontamos como limitação desta pesquisa o emprego das revistas "SA" e "SF" e das teses de livre-docência como parâmetros de análise da produção científica da Instituição, dado que essa produção vai muito além dessas publicações. No entanto, pensamos que essas podem ser tomadas como indicadores importantes da produção hegemônica, pois são publicações profundamente vinculadas à Instituição. Isso não significa, no entanto, que não existam pesquisadores da ESALQ que empreguem o pensamento sistêmico, mas, pelos resultados apresentados podemos supor que estes pesquisadores não encontram espaços nas publicações da Instituição. Talvez possamos até ir mais longe e supor que eles não são capazes de interferir nos rumos das publicações da Instituição e também, que não estão ascendendo na carreira, dado o caráter das teses de livre-docência e seu papel na carreira docente. 


\section{REFERÊNCIAS BIBLIOGRÁFICAS}

ACOT, P. História da ecologia. 2.ed. Rio de Janeiro: Campus, 1990. 212p.

ALLEONI, L.R.F. Participação de autores e revisores externos na Scientia Agricola. Scientia Agricola, v.59, n.2, p.1-2, abr.jun. 2002.

ALMEIDA JÚNIOR, A.; QUEDA, O. Trote na ESALQ. Piracicaba: Antônio Ribeiro de Almeida Júnior e Oriowaldo Queda, 2003. 141p.

ALPHANDÉRY, P.; BITOUN, P.; DUPONT, Y. O equívoco ecológico: riscos políticos da inconseqüência. São Paulo: Brasiliense, 1992. 189p.

ÂNGELO, C. Brasil elabora plano para salvar Rio+10. Folha de S.Paulo. Folha Ciência, São Paulo, 22 mar. 2002. p.A16.

ASSOCIAÇÃO BRASILEIRA DE NORMAS TÉCNICAS. COMUNICAÇÃO DE ESTUDOS DE DOCUMENTAÇÃO. Normas ABNT sobre documentação: NB 62. Rio de Janeiro: ABNT, 1978. v.1. p.9-12.

BACHELARD, G. A formação do espírito científico. 2.ed. Rio de Janeiro: Contraponto, 1999. 314p.

BATISTA, J. Nota do Editor. Scientia Forestalis, n.50, p.7, dez. 1996. 
BERTALANFFY, L.V. Teoria geral dos sistemas. Petrópolis: Vozes, 1973. 351p.

BIANCHI, F. O caminho do método. In: VEGA, A.P.; NASCIMENTO, E.P. (Org.). O pensar complexo: Edgar Morin e a crise da modernidade. 2.ed. Rio de Janeiro: Garamond, 1999. p.119-127.

BOFF, L. Saber cuidar: ética do humano - compaixão pela terra. 5.ed. Petrópolis: Vozes, 1999. 199p.

BONALUME NETO, R. USP faz 25\% da ciência do país com 10\% de pesquisadores. Folha de S.Paulo. USP 10 anos, São Paulo, 23 jan. 2004 . p.8.

BUARQUE, C. Por uma ecologia universitária. In: HOYOS, J.L.B. (Org.) Interdisciplinaridade: (re) invenção de um saber. NUMA (Núcleo de Meio Ambiente). Brasília, n.5, 1993, p. 9-24.

CAPRA, F. O ponto de mutação: a ciência, a sociedade e a cultura emergente. São Paulo: Cultrix, 1982. 447p.

CAPRA, F. A teia da vida: uma nova compreensão científica dos sistemas vivos. São Paulo: Cultrix, 1996. 256p.

CASTORIADIS, C. As encruzilhadas do labirinto I. Rio de Janeiro: Paz e Terra, 1987. 335p.

CASTRO, C.M. Há produção científica no Brasil? Revista Ciência e Cultura, n.37, supl.7, p.165-187, jul.1985.

CHAUÍ, M. Escritos sobre a universidade. São Paulo: Vozes, 2001. 205p. 
COnStAnTINO, L. Desmatamento na Amazônia cresce 2\%. Folha de S.Paulo. Folha Ciência, São Paulo, 08 abr. 2002. p.A16.

DESTÁCIO, M.C. Jornalismo científico e divulgação científica. In: KREINZ, G.; PAVAN, C. (Org.). Ética e divulgação científica. São Paulo: NJR/ECA/USP). São Paulo, 2002, p.93-102. (Coleção Divulgação Científica, v.5).

DIAS, G.F. Educação ambiental: princípios e práticas. 8.ed., São Paulo: Gaia, 2003. 551p.

DI CIOMMO, R.C. Ecofeminismo e educação ambiental. São Paulo: Uniube, 1999. $264 p$.

ESALQ 100 anos: um olhar entre o passado e o futuro. REICHARDT, K (Ed.). São Paulo: Prêmio, 2001. 193p.

FLORIANI, D. Marcos conceituais para o desenvolvimento interdisciplinar. In: PHILLIP JÚNIOR, A.; TUCCI, C.E.M.; HOGAN, D.J.; NAVEGANTES, R. (Ed.) Interdisciplinaridade em ciências ambientais. São Paulo: Sigmus, 2000. p.95107.

FLOR, A. Amazônia eleva Brasil a grande poluidor. Folha de S.Paulo. Folha Ciência, São Paulo, 9 dez. 2004. p.A18.

GARVEY, W.D. Communication: the essence of science. Oxford: Pergamon, 1979. 332p.

GIDDENS, A. As conseqüências da modernidade. São Paulo: Unesp, 1991. 117p. 
GOIS, A. IBGE aponta buraco em sustentabilidade. Folha de S.Paulo. Folha Ciência, São Paulo, 24 jun. 2002. p.A18.

GOMES, I.M.A. Revistas de divulgação científica: um panorama brasileiro. Revista Ciência \& Ambiente. v.1, p.95-107, jun.1990.

GONÇALVES, C.N.P. Os (des) caminhos do meio ambiente. 6.ed. São Paulo: Contexto, 1998. 148p.

HERSCHMAN, A. The primary journal: past, present and future. Journal of Chemical Documentation, v.10, n.1, p.37-42, 1970.

IANNI, O. Teorias da globalização. 6.ed. Rio de Janeiro: Civilização Brasileira, 1998. 225p.

KITAMURA, P.C.; IRIAS, L.J.M. O profissional de pesquisa \& desenvolvimento rural para os novos tempos. Cadernos de Ciência \& Tecnologia. v.19, p.119-134, jan/abr.2002.

KNAPP, L. Pró-reitor da USP quer pesquisa integrada. Nota de OLIVEIRA, Luiz Nunes de. O Estado de S.Paulo. Caderno Geral, São Paulo, 27 jan. 2002. p.A8.

KUHN, T.S. A estrutura das revoluções científicas. 5.ed. São Paulo: Perspectiva, 2000. 257p.

KUNSCH, M.M. Universidade e comunicação na edificação da sociedade. São Paulo: Loyola, 1992. 195p.

LE COADIC, Y. A ciência da informação. Brasília: Briquet de Lemos/Livros, 1996. 199p. 
LEFF, E. Complexidade, interdisciplinaridade e saber ambiental. In: PHILLIP JÚNIOR, A.; TUCCI, C.E.M.; HOGAN, D.J.; NAVEGANTES, R. (Ed.) Interdisciplinaridade em ciências ambientais. São Paulo: Sigmus, 2000, p.1951.

LEFF, E. Epistemologia ambiental. 2.ed. São Paulo: Cortez, 2002a. 240p.

LEFF, E. Saber ambiental: sustentabilidade, racionalidade, complexidade e poder. 2.ed. Rio de Janeiro: Vozes, 2002b. 343p.

LEITE, M. Plos e SciELO dão o que falar. Folha de S.Paulo. Caderno Mais, São Paulo, 16 nov. 2003a. p.18.

LEITE, M. Tamanho e documento da pesquisa brasileira. Folha de S.Paulo. Caderno Mais, São Paulo, 30 nov. 2003b. p.18.

LEITE, R.C.C. A reforma universitária e o corporativismo. Folha de S.Paulo. Tendências/Debates, São Paulo, 07 abr. 2004. p.A3.

LIMA, J.C.V. Divulgação científica e sociedade. http://www.revista pesquisafapesp.br (20 out. 2002).

MACHADO, P. de A. Ecologia humana. São Paulo: Cortez, 1984. 173p.

MARCOS FILHO, J. Palavra do diretor. In: ESALQ 100 anos: um olhar entre o passado e o futuro. REICHARD, K (Ed.), São Paulo: Prêmio, 2001, p.12-15.

MASSARINI, L; MOREIRA, I.C. A retórica e a ciência dos artigos originais à divulgação científica. Revista Ciência \& Ambiente, v.1, p.31-47, Jun. 1990. 
MEADOWS, A.J. A comunicação científica. Brasília: Briquet de Lemos/Livros, 1999. 268p.

MELFI, A.J. A realidade da USP. Folha de S.Paulo. Tendências/Debates, São Paulo, 9 jun. 2002. p.A3.

MIRANDA, D.B. O periódico científico como veículo de comunicação: uma revisão de literatura. Revista Ciência da Informação, v.25, n.3, p.375-380, 1996.

MORIN, E. Ciência com consciência. Rio de Janeiro: Bertrand Brasil, 1996. 336p.

MORIN, E. Por uma reforma do pensamento. In: VEGA, A.P.; NASCIMENTO, E.P. (Org.). O pensar complexo: Edgar Morin e a crise da modernidade. 2.ed. Rio de Janeiro: Garamond, 1999. p.21-34.

MORIN, E. Notas para um "Emílio" contemporâneo. In: VEGA, A.P.; ALMEIDA, C.R.S.; PETRAGLIA, I. (Org). Edgar Morin: ética, cultura e educação. São Paulo: Cortez, 2001. p.149-155.

MORIN, E. A cabeça bem-feita. 7.ed. Rio de Janeiro: Bertrand Brasil, 2002a. 128p.

MORIN, E. A religação dos saberes: o desafio do século XXI. 2.ed. Rio de Janeiro: Bertrand Brasil, 2002b. 583p.

MORIN, E. O método 1: a natureza da natureza. Porto Alegre: Sulina, 2002c. 480p.

MORIN, E. Os setes saberes necessários à educação do futuro. 5.ed. Brasília: Cortez, 2002d. 118p. 
MORIN, E.; KERN, A.B. Terra-Pátria. 3.ed. Porto Alegre: Editora Sulina, 2002. 184p.

NOJIMOTO, T. A pesquisa experimental agrícola universitária paulista: uma análise crítica e metodológica a partir das teses de livre-docência. Botucatu, 1996. 322p. Tese (Livre-Docência) - Faculdade de Ciências Agronômicas, Universidade Estadual Paulista “Júlio de Mesquita”.

PERECIM, M.T. Os passos do saber. A Escola Agrícola Prática Luiz de Queiroz. São Paulo, 2002. 551p. Tese (Doutorado) - Faculdade de Filosofia, Letras e Ciências Humanas, Universidade de São Paulo.

POBLACIÓN, D.A. Globalização do conhecimento e difusão da produção científica gerada na universidade brasileira. Revista Brasileira de Comunicação, v. 17, n.1, p.121-138, jan./jun. 1994.

POBLACIÓN, D.A.; GOLDENBERG, S.; MONTERO, E.F.S.; MOREIRA, M.B.; PELIZZON, R.F. Revistas brasileiras publicadoras de artigos científicos em cirurgia. I - Características estruturais e administrativas das revistas. Revista Acta Cirúrgica Brasileira. v. 17, n.6, p.359-369, 2002.

POLAKOVIC, G. O homem consome e a Terra não consegue repor. O Estado de S.Paulo. Geral/Ambiente, São Paulo. 30 jun. 2002. p.A15.

RAVEN, P.; LESHNER, A. A ciência contra a desigualdade. Folha de S.Paulo. Tendências/Debates, São Paulo, 25 ago. 2002. p.A3.

REICHARDT, K. Nota do Editor. Scientia Agricola, v.49, n.especial, 1992.

REICHARDT, K. Nota do Editor. Scientia Agricola, v.55, n.1, jan./abr. 1998. 
REICHARDT, K. Editorial. Scientia Agricola, v.57, n.1, jan./mar. 2000.

REICHARDT, K. Prefácio. ESALQ 100 anos: um olhar entre o passado e o futuro. REICHARD, K (Ed.), São Paulo: Prêmio, 2001. p.18-21.

RIBEIRO, R.J. Por uma SBPC com maior atuação social. Folha de S.Paulo. Tendências/Debates, São Paulo, 13 mai. 2003. p.A3.

RIBEIRO, W.C. A ordem ambiental internacional. São Paulo: Contexto, 2001. 176p.

ROCHA NETO, I. Há produção científica no Brasil? Atualização e crítica: uma contribuição para o processo de avaliação \& perspectivas - versão sintética. Revista de Educação Brasileira, v.21, n.10, p.17-32, 1988.

SÁ, S. Implicações interdisciplinares para um programa de estudos ambientais. In: HOYOS, J.L.B. (Org.) Interdisciplinaridade: (re) invenção de um saber. Brasília: NUMA (Núcleo de Meio Ambiente), n.5, 1993. p. 103-128.

SANTOS, B.S. A crítica da razão indolente: contra o desperdício da experiência. 3.ed. São Paulo: Cortez, 2001a. 415p.

SANTOS, B.S. Pelas mãos de Alice: o social e o político na pós-modernidade. 8.ed. São Paulo: Cortez, 2001b. 348p.

SANTOS, J.E. dos; SATO, M. Universidade e ambientalismo - encontros não são despedidas. In: SANTOS, J.E.dos; SATO, M. (Org.) A contribuição da educação ambiental à esperança de pandora. São Carlos: Rima, 2001. p.31-49. 
SANTOS, M. Técnica, espaço, tempo: globalização e meio técnico-científico informacional. São Paulo: Hucitec, 1994. 190 p.

SCIENTIA AGRICOLA. Piracicaba: ESALQ-USP, 1992- .Continuação de: Anais da Escola Superior de Agricultura "Luiz de Queiroz". Periódicos de 1998 a 2002.

SCIENTIA FORESTALIS. Piracicaba: IPEF-ESALQ-USP, 1970- .Continuação de: Revista IPEF. Periódicos de 1998 a 2002.

SEIFFERT, N.F. O desafio da pesquisa ambiental. Cadernos Ciência \& Tecnologia. v.15, n.3, p.103-122, set./dez. 1998.

SEREZA, H.C. A alternativa de Morin à catástrofe provável. O Estado de S.Paulo. Caderno 2/Cultura, São Paulo, 25 ago. 2002. p.D6.

SORRENTINO, M. Educação ambiental e universidade: um estudo de caso. São Paulo, 1995. 263p. Tese (Doutorado) - Faculdade de Educação, Universidade de São Paulo.

SPINAK, E. Los analises cuantitativos de la literatura científica y su validez para juzgar la producción latinoamericana. Boletim Oficina Sanit Panam, v.2, n.120, p.139-147, 1996.

TARGINO, M.G. Comunicação científica: uma revisão de seus elementos básicos. Revista Informação \& Sociedade, v.10, n.2, p.37-85, 2000.

TARGINO, M.G. Divulgação de resultado como expressão da função social do pesquisador. Revista Brasileira de Ciências da Comunicação, v.29, n.1, p.11-35, jan./jun. 2001. 
TEICH, D.H. A terra pede socorro. Revista Veja, v.35, n.33, p.80-87, ago. 2002.

VEGA, A.P.; ALMEIDA, C.R.S.; PETRAGLIA, I. Edgar Morin: ética, cultura e educação. São Paulo: Cortez, 2001. 175p.

VIOLA, M.A. Desenvolvimento e cidadania: desafios para as ciências sociais. 3.ed. São Paulo: Cortez, 2001. 219p.

ZANONI, M. Práticas interdisciplinares em grupos consolidados. In: PHILLIP JÚNIOR, A.; TUCCI, C.E.M.; HOGAN, D.J.; NAVEGANTES, R. (Ed.) Interdisciplinaridade em ciências ambientais. São Paulo: Sigmus, 2000. p.111130.

WEBER, R. Diálogos com cientistas e sábios: a busca da unidade. São Paulo: Cultrix, 1986. 302p.

WOODWAARD, H. Identidade e diferença: uma introdução teórica e conceitual. In: SILVA, T.T. da. (Org.) Identidade e diferença: a perspectiva dos estudos culturais. Petrópolis: Vozes, 2000. p.7-72.

YAHN, V.G. Avaliação de periódicos brasileiros: um estudo na área de agricultura. Rio de Janeiro, 1983. 144p. Dissertação (Mestrado) - Universidade Federal do Rio de Janeiro. 
Relação de sites acessados:

http://www.cabi-publishing.org (14 Fev. 2004)

http://www.cpac.embrapa.br/biblioteca (03 Fev. 2004)

http.//www.dibd.ESALQ.usp.br/qualis/Qualis_Ciencias_Agrarias.xls (15 Fev. 2004)

http://www.ipef.br/publicações/scientia/sobre.html (04 Jan. 2003)

http://www.lusodoc.pt (13 Fev. 2004)

http://www.mma.gov.br/port/se/agen21/cap35.html (28 Fev. 2004)

http://www.revistapesquisafapesp.br (20 Out. 2002)

http://www.scielo.br (10 Nov. 2002 e 24 Jul. 2003)

http://www.sistemas.usp.br/anuario (16 a 19 Nov. 2004) 
APÊNDICES 


\section{APÊNDICE 1}

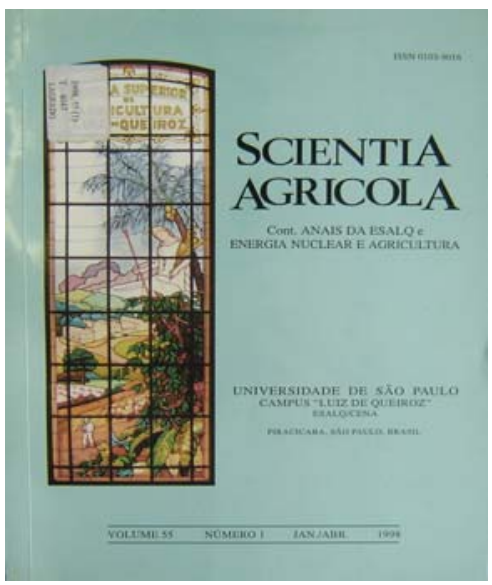

FOTO 1: Foto digitalizada da capa da revista Scientia Agricola, v.58, n.1, jan./abr.1998.

Observação: Este modelo de capa foi utilizado até o exemplar: v.56, n.4, out./dez. 1999.

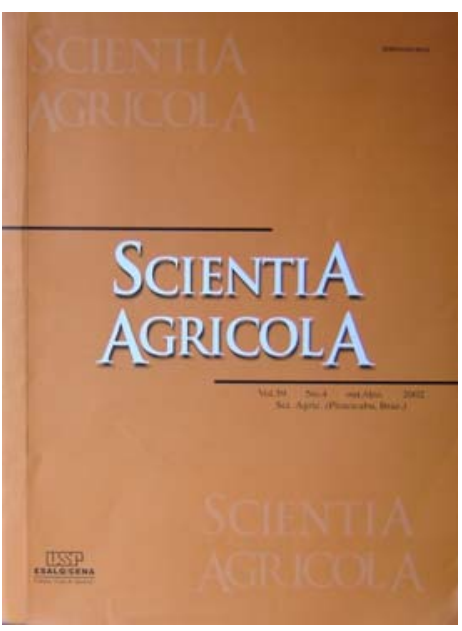

FOTO 2: Foto digitalizada da capa da revista Scientia Agricola, v.59, n.4, out./dez.2002.

Observação: Este modelo de capa surgiu a partir do exemplar: v.57, n.1, jan./maio 2000. 


\section{APÊNDICE 2}

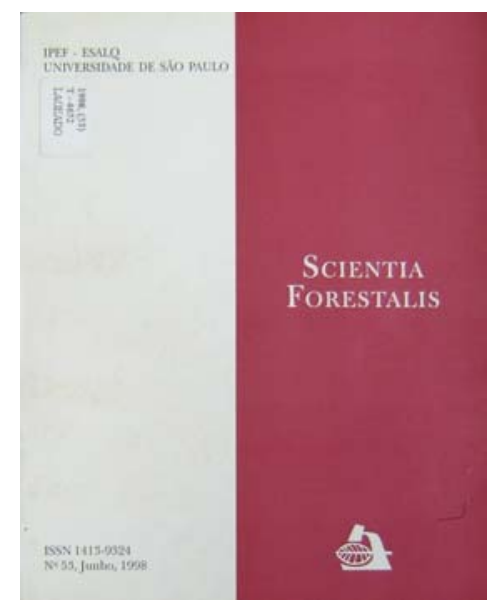

FOTO 3: Foto digitalizada da capa da revista Scientia Forestalis, n.53, jun./1998.

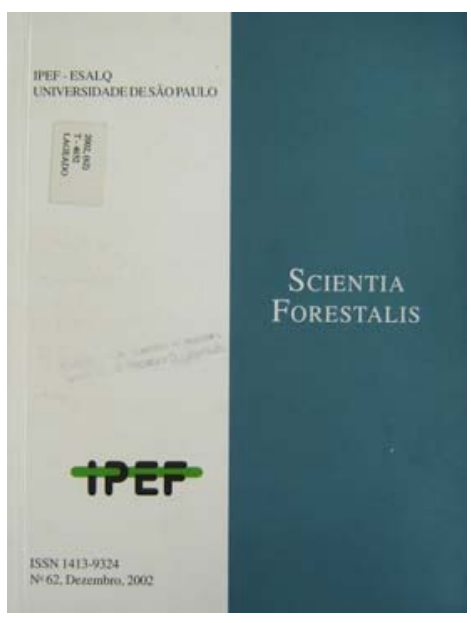

FOTO 4: Foto digitalizada da capa da revista Scientia Forestalis, n.62, dez./2002. 


\section{APÊNDICE 3}

\section{ANÁLISE DA COMUNICAÇÃO CIENTÍFICA ELETRÔNICA, 2001- 2002}

- Levantamento das bases onde as revistas "SA" e "SF" estavam indexadas;

- Análise das revistas "SA" e "SF" em pelo menos uma das bases de dados:

$\checkmark$ Classificação em relação às demais revistas da coleção da base de dados, número de volumes disponíveis, números de acessos, artigos mais acessados, números de citações (revistas citadas e revistas citantes) e

$\checkmark$ Levantamento e análise da estrutura dos artigos quanto ao idioma: português e/ou inglês dos textos, sumários e descritores (palavras-chave), formato dos textos: Portable Document Format (PDF) e/ou Hiper Text Markup Language (HTML) e quanto ao conteúdo (áreas temáticas).

\section{Levantamento das bases onde as revistas estão indexadas}

A “Scientia Agricola" tem resumo em português e inglês e os respectivos indicadores (palavras-chave) nas seguintes bases: SciELO, Agrarian Information System (AGRIS), Base Bibliográfica da Agricultura Brasileira (AGROBASE), CABi, International Nuclear Information System (INIS) e Tropag \& Rural. Na base de dados SciELO os artigos estão na íntegra, e os resumos e as palavraschave em português e inglês. 


\section{A "REVISTA SCIENTIA AGRICOLA" NA BASE DE DADOS SciELO (SCIENTIFIC ELETRONIC LIBRARY ONLINE)}

A SciELO é uma biblioteca eletrônica que abrange uma coleção selecionada de periódicos científicos brasileiros. O site é parte do projeto FAPESP (Fundação de Amparo à Pesquisa do Estado de São Paulo)/BIREME (Centro LatinoAmericano e do Caribe de Informação em Ciências da Saúde)/CNPq (Conselho Nacional de Desenvolvimento Científico e Tecnológico) e é constantemente atualizado tanto no seu formato como no seu conteúdo, conforme os avanços e os resultados do projeto.

O objetivo do projeto é o desenvolvimento de uma metodologia comum para a preparação, armazenamento, disseminação e avaliação da produção científica de diversos países em formato eletrônico. As revistas da coleção são do Brasil, Chile, Cuba, Espanha são indexadas por assunto: Biologia, Ciências Agrárias (18 revistas indexadas), Ciências Sociais, Engenharia, Letras, Psicologia, Ciências da Saúde, Saúde Materno-Infantil, Veterinária e Zootecnia, Saúde Pública e Odontologia, (http://www.scielo.br, 24 Jun. 2003).

"A boa notícia, para quem tem interesse em publicações científicas brasileiras, é que o país já tem um sistema de livre acesso, a 'Scientific Eletronic Library Online' (www.scielo.br), uma biblioteca eletrônica com 114 periódicos nacionais, a maioria de interesse bem mais restrito que 'Nature' ou 'Science'. A SciELO tem recebido mais de 326 mil consultas por dia - o tipo de aparição bem vinda” (Leite, 2003a, p.18).

\section{Tempo de Publicação}

Apesar de surgir em 1992, a revista Scientia Agricola passou a ser indexada na base de dados SciELO a partir de 1996 (volume 53) com dois números, e de 1999 até 2002 passou a ter quatro números indexados por ano.

Na base de dados SciELO estavam todos os volumes editados no período de 1996 a 2002. 
Classificação quanto ao número de exemplares em relação às demais revistas da coleção do SciELO

A coleção da biblioteca da base de dados SciELO possui 92 periódicos nacionais e internacionais listados em ordem alfabética. Em termos de quantidade de volumes indexados, a revista Scientia Agricola ocupa o $11^{\circ}$ lugar. Há uma maior predominância de periódicos na área de saúde, embora configure em $7^{0}$ lugar a revista “Pesquisa Agropecuária Brasileira”.

TABELA 20. Relação da coleção da Biblioteca disponível na base de dados SciELO e classificação da revista "SA" quanto ao número de exemplares indexados

\begin{tabular}{clc}
\hline CLASSIFICAÇÃOO & \multicolumn{1}{c}{ PERIÓDICO } & $\begin{array}{c}\mathbf{N}^{\mathbf{o}} \\
\text { EXEMPLARES }\end{array}$ \\
\hline $\mathbf{1}^{\mathbf{0}}$ & Brazilian Journal of Medical and Biological & 71 \\
$\mathbf{2}^{\mathbf{0}}$ & Research & 69 \\
$\mathbf{3}^{\mathbf{0}}$ & Arquivos Brasileiros de Cardiologia & 47 \\
$\mathbf{4}^{\mathbf{0}}$ & Memórias do Instituto Oswaldo Cruz & 43 \\
$\mathbf{5}^{\mathbf{0}}$ & Cadernos de Saúde Pública & 39 \\
$\mathbf{6}^{\mathbf{0}}$ & Revista de Saúde Pública & 34 \\
& Revista da Sociedade Brasileira de Medicina & 34 \\
& Tropical & 31 \\
$\mathbf{7}^{\mathbf{0}}$ & Revista do Instituto de Medicina Tropical de & 28 \\
$\mathbf{8}^{\mathbf{o}}$ & São Paulo & 28 \\
$\mathbf{9}^{\mathbf{o}}$ & Pesquisa Agropecuária Brasileira & 27 \\
$\mathbf{1 0}^{\mathbf{0}}$ & Acta Cirúrgica Brasileira & 26 \\
$\mathbf{1 1}^{\mathbf{0}}$ & Arquivos de Neuro-Psiquiatria & 26 \\
\hline
\end{tabular}

Fonte: SciELO, 2002.

\section{Número de artigos disponíveis}

Conforme mencionamos anteriormente a revista "SA" passou a ser indexada na base SciELO a partir de 1996, e até o ano de 2002 teve 25 números distribuídos. 
TABELA 21. Volumes disponíveis na base de dados SciELO no período de 1996 a 2002

\begin{tabular}{|c|c|c|}
\hline ANO & VOLUME & NÚMERO \\
\hline 1996 & 53 & $12-3$ \\
\hline 1997 & 54 & $1-23$ \\
\hline 1998 & 55 & 123 especial \\
\hline 1999 & 56 & 12344 supl. \\
\hline 2000 & 57 & 1234 \\
\hline 2001 & 58 & 1234 \\
\hline 2002 & 59 & 1234 \\
\hline TOTAL & 07 & 25 \\
\hline
\end{tabular}

Fonte: SciELO, 2002

\section{Número de acessos}

Na tabela abaixo constam os números de acessos das seções de todos os volumes da revista "SA" no período de 2001 a 2002. Os dados foram implantados na base a partir de 16 de outubro de 1998; logo, não foram incluídos os acessos aos volumes anteriores a esta data.

TABELA 22. Acesso aos números da revista "SA" realizado no período de 2001 a 2002

\begin{tabular}{lrc}
\hline & \multicolumn{2}{c}{$\mathbf{N}^{\mathbf{0}}$ de acessos } \\
\hline HOME & $\mathbf{2 0 0 1}$ & $2002^{*}$ \\
SUMÁRIO & 13.608 & $\mathbf{2 1 . 0 2 9}$ \\
ARTIGOS & 10.961 & $\mathbf{1 3 . 8 7 2}$ \\
OUTROS & 32.153 & $\mathbf{4 8 . 5 2 1}$ \\
\multicolumn{1}{c}{ TOTAL } & 12.564 & $\mathbf{2 0 . 8 3 0}$ \\
\hline
\end{tabular}

Fonte: SciELO, 2002.

*Até 09/11/2002

Nota-se na tabela acima um aumento de 15.966 acessos em 2002 em relação ao ano de 2001, considerando também que o levantamento foi realizado até 09 de novembro de 2002, o que significa que esse número pode ter aumentando até 31 de dezembro do mesmo ano.

\section{Artigos mais acessados}

Segundo Alleoni (2002, p.2), “até fevereiro de 2002, os três artigos mais consultados da Scientia Agricola tiveram 1305 acessos e dentre os periódicos incluídos na base de dados a Scientia Agricola é um dos mais acessados”. 
Analisamos o número de acesso dos três artigos mais consultados da revista de 27 de fevereiro de 1998 (data de início da base) até 09 de novembro de 2002 e verificamos 1910 acessos, 605 a mais desde fevereiro de 2002.

Desses três artigos ${ }^{13}$, o primeiro* (vol.56, n²2, 1999) teve 723 acessos, o segundo** (vol.57, $\left.\mathrm{n}^{\circ} 1,2000\right)$ teve 686 e o terceiro*** (vol.58, $\left.\mathrm{n}^{\circ} 1,2001\right)$ teve 501 acessos. Podemos notar que o artigo mais acessado foi publicado em 1999, está há mais tempo indexado na base de dados, o que contribui para um maior número de acessos em relação aos outros dois artigos, que foram publicados em 2000 e 2001.

TABELA 23. Classificação dos fascículos de 2001 em relação aos fascículos* mais visitados da revista "SA", medida pelo número de acessos aos resumos e aos artigos em HTML e em PDF, (de janeiro a dezembro de 2001)

\begin{tabular}{ccc}
\hline CLASSIFICAÇÃO & $\mathbf{N}^{\circ}$ DE ACESSOS & \multicolumn{1}{c}{ FASCÍCULOS } \\
\hline $2^{\circ}$ & 4514 & v.58, $\mathrm{n}^{\circ} 1$, jan./mar.2001 \\
$4^{\circ}$ & 2995 & v.58, $\mathrm{n}^{\circ} 3$, jul./set. 2001 \\
$8^{\circ}$ & 2518 & v.58, $\mathrm{n}^{\circ} 2$, abr./jun. 2001 \\
$21^{\circ}$ & 1125 & v.58 $\mathrm{n}^{\circ} 4$, out./dez. 2001 \\
TOTAL $^{\circ}$ & $\mathbf{1 1 . 1 5 2}$ & \\
\hline
\end{tabular}

Fonte: SciELO, 2002.

*Total de fascículos: 23

TABELA 24. Classificação dos fascículos de 2002 em relação aos fascículos* mais visitados da revista "SA", medida pelo número de acessos aos resumos e aos artigos em HTML e em PDF, (de janeiro a 09 de novembro de 2002)

\begin{tabular}{ccc}
\hline CLASSIFICAÇÃO & $\mathbf{N}^{\mathbf{0}}$ DE ACESSOS & \multicolumn{1}{c}{ FASCÍCULOS } \\
\hline $7^{\circ}$ & 4013 & v.59, $\mathrm{n}^{\circ} 2$, abr./jun. 2002 \\
$8^{\circ}$ & 3858 & v.59, $\mathrm{n}^{\circ} 1$, jan./mar. 2002 \\
$11^{\circ}$ & 3204 & v.59, $\mathrm{n}^{\circ} 3$, jul./set. 2002 \\
$23^{\circ}$ & 799 & v. $59 \mathrm{n}^{\circ} 4$, out./dez. 2002 \\
TOTAL & $\mathbf{1 1 . 8 7 4}$ & \\
\hline
\end{tabular}

Fonte: SciELO, 2002.

*Total de fascículos: 23

${ }^{13}\left(^{*}\right)$ JAHNEL, M.C. et al. Maturidade de composto de lixo urbano. Scientia Agricola., v.56, n.2, p.301-304, abr./jun. 1999.

$\left.{ }^{* *}\right)$ KLUTHCOUSKI, J. et al. Manejo do solo e o rendimento de soja, milho, feijão e arroz em plantio direto. Scientia Agricola, v.57, n.1, p.97-104, jan./mar. 2000.

(***) OHSE, S., et al. Qualidade de cultivares de alface produzidos em hidroponia. Scientia Agricola, v.58, n.1, p.181-185, jan./mar. 2001. 


\section{Número de citações}

\section{- Revistas citadas pela revista "SA" no período de 2001 a 2002.}

\section{Ao analisar o "Relatório de Citações de Revistas"} (http://www.scielo.br, 10 Nov. 2002), elaborado pela base SciELO, observamos que os artigos da revista "SA" no ano de 2001 citaram 323 revistas nacionais e internacionais num total de 1720 citações. Das 323 revistas analisamos as doze mais citadas pela revista, conforme os dados das Tabelas 24 e 25.

Ainda em relação ao número revistas citadas na revista "SA", é importante salientar que a revista mais citada em artigos de 2001 foi a "Revista Brasileira de Ciências do Solo” (83 citações) que, embora não esteja indexada na SciELO, estava entre as primeiras 50 revistas mais citadas. A segunda era a própria revista "SA" com 28 citações.

Nos artigos da revista "SA", em primeiro lugar estava a revista “Agropecuária Brasileira" citada 49 vezes tendo sido indexada em 2000 na SciELO. Em segundo lugar com 45 citações, encontra-se a revista "Brasileira de Ciência e Movimento", e em terceiro, com 36 citações, ficou a revista "Soil Science of America Journal”; a própria "SA" foi citada 19 vezes, ocupando o $10^{\circ}$ lugar juntamente com outras quatro revistas.

Notamos que em relação às doze principais revistas citadas pela SA em 2001, cinco estavam indexadas na base SciELO, em 2002, apenas três. Logo, neste ano prevaleceram as revistas não indexadas na referida base.

- Revistas que citaram os artigos da revista “SA” no período de 2001 a 2002.

Em relação às revistas nacionais que citaram artigos da revista "SA" no ano de 2001, no mesmo "Relatório de Citações de Revistas" (http://www.scielo.br, 10 Nov. 2002) da base SciELO havia apenas sete revistas, incluindo a própria "SA"ela mesma, num total de 50 citações.

Na Tabela 27 podem ser constatadas todas as revistas indexadas na base SciELO. Concluímos que a revista "SA" citou com mais freqüência as revistas brasileiras do que o inverso, e sua auto-citação correspondeu a 28 vezes, destacando-se das demais. 
TABELA 25. Relação de revistas citadas pela revista "SA" no ano de 2001

\begin{tabular}{|c|c|c|c|c|c|c|c|c|c|c|c|c|}
\hline \multirow[t]{2}{*}{ Revistas Citadas } & \multirow[b]{2}{*}{$<1992$} & \multicolumn{11}{|c|}{2001} \\
\hline & & 1992 & 1993 & 1994 & 1995 & 1996 & 1997 & 1998 & 1999 & 2000 & 2001 & TOTAL \\
\hline R.Bras.Ci.Solo & 28 & 6 & 7 & 6 & 2 & 3 & 7 & 11 & 6 & 7 & - & 83 \\
\hline Sci Agric.*(Piracicaba, Braz.) & - & - & 2 & 2 & 2 & 1 & - & 3 & 9 & 8 & 1 & 28 \\
\hline $\begin{array}{l}\text { Anais da Sociedade de } \\
\text { Entomologia do Brasil }\end{array}$ & 7 & 1 & 3 & 1 & - & 2 & 3 & - & 1 & 1 & - & 19 \\
\hline Rev.Bras.Sementes & 2 & - & - & - & 2 & 2 & 2 & 5 & 2 & - & - & 15 \\
\hline Bragantia* & 13 & - & - & 1 & - & - & - & - & - & - & - & 14 \\
\hline Braz.J.Genet.* & 5 & 1 & 2 & 4 & 1 & - & 1 & - & - & - & - & 14 \\
\hline Rev.Agric. & 9 & 1 & - & - & - & 1 & 2 & - & - & - & - & 13 \\
\hline Fitopatol. Bras.* & 3 & - & 1 & - & 2 & 1 & 1 & 1 & - & - & - & 9 \\
\hline Hortic.Bras. & 7 & - & - & - & 1 & - & - & - & 1 & - & - & 9 \\
\hline Laranja & 3 & - & 1 & - & 1 & 2 & 1 & - & - & - & - & 8 \\
\hline Planta & 6 & - & 1 & - & - & - & - & 1 & - & - & - & 8 \\
\hline Ciênc.Rural* & - & - & - & - & - & - & - & - & 2 & 4 & 1 & 7 \\
\hline
\end{tabular}

Fonte: SciELO, 2002

(*)Revistas incluídas na base de dados SciELO. 
TABELA 26. Relação de revistas citadas pela revista "SA" no ano de 2002

\begin{tabular}{|c|c|c|c|c|c|c|c|c|c|c|c|c|}
\hline \multirow[t]{2}{*}{ Revistas Citadas } & & \multicolumn{11}{|c|}{2002} \\
\hline & $<1993$ & 1993 & 1994 & 1995 & 1996 & 1997 & 1998 & 1999 & 2000 & 2001 & 2002 & TOTAL \\
\hline Pesq.Agropec.Bras.* & 21 & 2 & 6 & 4 & 3 & 4 & - & 8 & 1 & - & - & 49 \\
\hline $\begin{array}{l}\text { Revista Brasileira de Ciência e } \\
\text { Movimento }\end{array}$ & 16 & 2 & 2 & 2 & 4 & - & 6 & 4 & 7 & 2 & - & 45 \\
\hline $\begin{array}{l}\text { Soil Science Society of America } \\
\text { Journal }\end{array}$ & 33 & - & - & 1 & 1 & - & 1 & - & - & - & - & 36 \\
\hline $\begin{array}{l}\text { Anais da Sociedade } \\
\text { Entomológica do Brasil }\end{array}$ & 14 & 3 & 1 & 2 & 3 & 1 & 2 & 3 & 3 & - & - & 32 \\
\hline $\begin{array}{l}\text { J Econ Entomol } \\
\text { Plant Physiology } \\
\text { Enviromental Entomology }\end{array}$ & $\begin{array}{l}17 \\
18 \\
16\end{array}$ & $\begin{array}{l}- \\
4 \\
-\end{array}$ & $\begin{array}{l}3 \\
1 \\
2\end{array}$ & $\begin{array}{l}3 \\
2 \\
1\end{array}$ & $\begin{array}{l}2 \\
- \\
3\end{array}$ & $\begin{array}{l}2 \\
- \\
1\end{array}$ & $\begin{array}{l}1 \\
- \\
3\end{array}$ & $\begin{array}{l}1 \\
1 \\
-\end{array}$ & $\begin{array}{l}- \\
-\end{array}$ & $\begin{array}{l}- \\
2 \\
-\end{array}$ & $\begin{array}{l}- \\
-\end{array}$ & $\begin{array}{l}29 \\
28 \\
26\end{array}$ \\
\hline $\begin{array}{l}\text { Bragantia* } \\
\text { J.Anim.Sci. } \\
\text { J.Agric.Food Chem. }\end{array}$ & $\begin{array}{c}13 \\
11 \\
7\end{array}$ & $\begin{array}{l}- \\
- \\
1\end{array}$ & $\begin{array}{l}4 \\
1 \\
-\end{array}$ & $\begin{array}{l}- \\
1\end{array}$ & $\begin{array}{l}- \\
3 \\
-\end{array}$ & $\begin{array}{l}- \\
3 \\
1\end{array}$ & $\begin{array}{l}1 \\
1 \\
4\end{array}$ & $\begin{array}{l}6 \\
- \\
2\end{array}$ & $\begin{array}{l}1 \\
- \\
3\end{array}$ & $\begin{array}{l}- \\
1 \\
1\end{array}$ & $\begin{array}{l}- \\
- \\
-\end{array}$ & $\begin{array}{l}25 \\
21 \\
19\end{array}$ \\
\hline $\begin{array}{l}\text { J.Dairy Sci. } \\
\text { Physiologia Plantarum }\end{array}$ & $\begin{array}{c}6 \\
11\end{array}$ & $\begin{array}{l}4 \\
-\end{array}$ & $\begin{array}{l}1 \\
-\end{array}$ & $\begin{array}{l}1 \\
3\end{array}$ & - & $\begin{array}{l}3 \\
4\end{array}$ & $\begin{array}{l}3 \\
-\end{array}$ & $\begin{array}{l}1 \\
-\end{array}$ & $\overline{1}$ & $\begin{array}{l}- \\
-\end{array}$ & $\begin{array}{l}- \\
-\end{array}$ & $\begin{array}{l}19 \\
19\end{array}$ \\
\hline $\begin{array}{l}\text { R.Soc.Bras.Zoot. } \\
\text { Sci.Agric.* (Piracicaba, Braz.) }\end{array}$ & $\begin{array}{l}10 \\
-\end{array}$ & $\begin{array}{l}2 \\
1\end{array}$ & $\begin{array}{l}3 \\
1\end{array}$ & $\begin{array}{l}4 \\
1\end{array}$ & $\begin{array}{l}- \\
-\end{array}$ & - & - & - & - & - & - & $\begin{array}{l}19 \\
19\end{array}$ \\
\hline
\end{tabular}

Fonte: SciELO, 2003

*Revistas incluídas na base de dados SciELO. 
TABELA 27. Relação de revistas que citaram artigos da revista “SA” no ano de 2001

\begin{tabular}{|c|c|c|c|c|c|c|c|c|c|c|c|c|}
\hline \multirow{2}{*}{ Revistas Citadas } & \multirow[b]{2}{*}{$<1992$} & \multicolumn{11}{|c|}{2001} \\
\hline & & 1992 & 1993 & 1994 & 1995 & 1996 & 1997 & 1998 & 1999 & 2000 & 2001 & TOTAL \\
\hline $\begin{array}{l}\text { Sci agric* } \\
\text { (Piracicaba, Braz.) }\end{array}$ & - & - & 2 & 2 & 2 & 1 & - & 3 & 9 & 8 & 1 & 28 \\
\hline Pesq. Agropec.Bras.* & - & 1 & 1 & 2 & - & 1 & 2 & - & 4 & - & - & 11 \\
\hline Neotrop. Entomol.* & - & - & 1 & -- & - & - & - & - & 1 & 2 & - & 4 \\
\hline Rev.Bras.Bot.* & - & - & - & - & - & 1 & - & - & 1 & - & - & 2 \\
\hline Rev.Bras.Frutic.* & - & - & - & - & 1 & - & - & - & 1 & - & - & 2 \\
\hline Rev.Bras.Zootec.* & - & - & - & - & 2 & - & - & - & - & - & - & 2 \\
\hline Bragantia* & - & - & - & - & - & - & - & 1 & - & - & - & 1 \\
\hline
\end{tabular}

Fonte: SciELO, 2002.

*Revistas incluídas na base de dados SciELO. 
TABELA 28. Relação de revistas que citaram artigos da revista "SA" no ano de 2002

\begin{tabular}{|c|c|c|c|c|c|c|c|c|c|c|c|c|}
\hline \multirow[t]{2}{*}{ Revistas Citadas } & \multirow[b]{2}{*}{$<1993$} & \multicolumn{11}{|c|}{2002} \\
\hline & & 1993 & 1994 & 1995 & 1996 & 1997 & 1998 & 1999 & 2000 & 2001 & 2002 & TOTAL \\
\hline Pesq.Agropec.Bras.* & - & 1 & 2 & 3 & 3 & 4 & 3 & 1 & 1 & 4 & - & 22 \\
\hline $\begin{array}{l}\text { Sci.agric.* } \\
\text { (Piracicaba, Braz.) }\end{array}$ & - & 1 & 1 & 1 & - & 3 & 2 & 2 & 9 & - & - & 19 \\
\hline Rev.Bras.Frutic.* & - & - & - & - & - & 1 & 3 & 4 & 3 & - & - & 11 \\
\hline R.Bras. Zootec.* & - & - & - & 3 & - & - & - & 2 & - & - & - & 5 \\
\hline Neotrop.Entomol.* & - & - & 1 & 1 & - & - & 1 & - & - & - & - & 3 \\
\hline Braz.J.Microbiol.* & - & - & - & - & - & - & 1 & 1 & - & - & - & 2 \\
\hline Hortic.Bras.* & - & - & - & - & - & - & - & - & 2 & - & - & 2 \\
\hline Braz.J.Biol.* & - & - & - & - & - & - & 1 & - & - & - & - & 1 \\
\hline Cienc.Rural** & - & - & - & 1 & - & - & - & - & - & - & - & 1 \\
\hline
\end{tabular}

Fonte: SciELO, 2003

*Revistas incluídas na base de dados SciELO. 
Na Tabela 28, notamos que em 2002 houve um total de 66 citações, ou seja, 16 citações a mais em relação ao ano anterior, além de contar com mais duas revistas. Das nove revistas que mais citaram a revista "SA", três eram em idioma inglês (“Braz.J.Biol.”, “Braz.J.Microbiol.” e “Neotrop.Entomol.”) e estavam indexadas na base SciELO na área de Ciências Biológicas, as demais estavam indexadas na área de Ciências Agrárias.

Notamos também que a revista "Pesquisa Agropecuária Brasileira" apresentou em 2002 o dobro de citações em relação a 2001 e a revista "SA" teve 9 citações a menos durante o mesmo período; mesmo assim, teve o maior número de auto-citações.

TABELA 29. Totalização* das principais revistas que citaram a revista "SA" no período de 2001 a 2002

\begin{tabular}{lc}
\hline \multicolumn{1}{c}{ Revistas } & $\mathrm{N}^{\circ}$ Total de Citações \\
\hline Scientia Agricola & $47(40,5 \%)$ \\
Pesq.Agropec.Bras. & $33(28,4 \%)$ \\
Rev.Bras.Frutic. & $13(11,2 \%)$ \\
R.Bras. Zootec. & $7(6,03 \%)$ \\
Neotrop.Entomol. & $7(6,02 \%)$ \\
\multicolumn{1}{c}{ TOTAL } & $\mathbf{1 0 7}(\mathbf{9 2 , 1 \% )}$ \\
\hline
\end{tabular}

*Número total de citações $=116$

Do total de 116 citações (Tabelas 27 e 28), a revista "SA" fez 47 citações (40,5\%), ou seja, quase metade das citações foram auto-citação.

Também notamos que a maioria das revistas citadas pela revista”SA” não estavam indexadas na base SciELO, enquanto que todas as revistas que citaram a revista "SA" estavam indexadas nessa base. Logo, pode-se supor que os artigos da revista "SA" não privilegiaram os periódicos indexados na base SciELO.

As Tabelas 27 e 28 contêm a lista de todas as revistas que citaram a “SA”, todas nacionais. O fato de autores da área de agrárias preferirem ser citados em periódicos nacionais foi verificado por Velho \& Krige ${ }^{14}$, citados por Castro (1985, p.184). Os autores afirmam que os pesquisadores da Faculdade de Viçosa e da ESALQ

\footnotetext{
${ }^{14}$ VELHO, L.; KRIGE, J. Publication and citation praticas of Brazilian agricultural scientists. Social Studies of
} Sciende, v.12, lv. 1984. 
"citam 44\% e 36\% dos artigos brasileiros em confronto com o fato de apenas um em cada cinco venezuelanos das áreas agrárias e sociais, cita suas próprias revistas”.

Segundo Spinak (1996, p.142), as ciências agrícolas tendem a ser de interesse local ou regional e grande parte dessa comunicação não segue canais formais internacionais. No Brasil, mais de $80 \%$ das investigações agrícolas se publicam em revistas nacionais.

Rocha Neto (1988, p.31) destaca que as Ciências Agrárias, cujos interesses temáticos são fortemente orientados para as questões nacionais e regionais, não seriam adequadamente veiculados em periódicos estrangeiros.

“(...) nos parece também falsa a conclusão de que os brasileiros tenham a maior propensão para publicações locais (...) É mais apropriado concluir que em função do perfil de base técnicocientífica brasileira e em função dos temas de interesse, sem necessariamente sofrer perda de qualidade, a ciência brasileira tem-se voltado mais para a solução e para investigação de problemas nacionais e regionais" (Rocha Neto, 1988, p.31).

\section{Levantamento e análise dos artigos}

Os textos da revistas "SA" estavam disponíveis em português e em inglês.

Os sumários variavam de número para número, ou seja, as seções não eram fixas, exemplos: Engenharia Agrícola, Agrometeorologia, Ciências Florestais etc. Tanto as seções como os resumos estavam em português e inglês.

Em todos os artigos analisados as palavras-chave estavam em português e inglês, assim como os resumos.

\section{Estrutura dos Artigos}

Analisamos a estrutura de 241 artigos equivalentes a oito volumes (quatro números por ano), sendo 121 artigos em 2001 e 120 em 2002. Todos os artigos de 2001 e 2002 estavam disponíveis na SciELO em formato pdf. Ressaltamos que foi com o número especial v.55 de 1998 (23 artigos em inglês) que surgiu o formato pdf da “Scientia Agricola” na SciELO. 
O formato pdf do programa Adobe disponibiliza todas as informações contidas no artigo (ex. páginas, volume, data etc).

\section{Conteúdo: áreas temáticas}

Nos anos de 2001 e 2002 podemos constatar maior número de artigos destinados às seções de Solo e Fitotecnia, conforme tabelas a seguir. Ressaltamos que até o ano de 1999 os artigos não eram categorizados, ou seja, as seções temáticas foram implantadas em 2000.

TABELA 30. Classificação dos artigos publicados no Volume 58 da revista "SA" no ano de 2001: levantamento do tipo de formato* disponível e idioma

\begin{tabular}{|c|c|c|c|c|}
\hline Números & $\begin{array}{c}\mathrm{N}^{\circ} 1 \\
\mathrm{jan} / \mathrm{mar}\end{array}$ & $\mathrm{N}^{\circ} 2$ abr/jun & $\begin{array}{c}\mathrm{N}^{\circ} 3 \\
\text { jul/set }\end{array}$ & $\begin{array}{c}\mathrm{N}^{\circ} 4 \\
\text { out/dez }\end{array}$ \\
\hline Ciência Animal e Pastagem & 2 art.: Port. & 2 art.: Port. & 2 art.: Port. & $\begin{array}{l}4 \text { art.: } \\
3 \text { Port. } \\
1 \text { Ingl. }\end{array}$ \\
\hline Engenharia Agrícola & 1 art.: Port. & - & 1 art.: Ingl. & - \\
\hline Entomologia & 2 art.: Port. & $\begin{array}{l}2 \text { art.: } \\
1 \text { Port. } \\
1 \text { Ingl. }\end{array}$ & 2 art.: Port. & $\begin{array}{l}3 \text { art.: } \\
2 \text { Port. } \\
1 \text { Ingl. }\end{array}$ \\
\hline $\begin{array}{l}\text { Fisiologia e Bioquímica das } \\
\text { Plantas }\end{array}$ & $\begin{array}{l}4 \text { art.: } \\
3 \text { Port. } \\
1 \text { Ingl. }\end{array}$ & 2 art.: Port. & $\begin{array}{l}3 \text { art.: } \\
2 \text { Port. } \\
1 \text { Ingl. }\end{array}$ & 2 art.: Port. \\
\hline Fitotecnia & 6 art.: Port. & $\begin{array}{c}5 \text { art.: } \\
4 \text { Port. } \\
1 \text { Ing. }\end{array}$ & $\begin{array}{l}4 \text { art.: } \\
3 \text { Port. } \\
1 \text { Ingl. }\end{array}$ & $\begin{array}{l}4 \text { art.: } \\
3 \text { Port. } \\
1 \text { Ingl. }\end{array}$ \\
\hline $\begin{array}{l}\text { Genética e Melhoramento de } \\
\text { Plantas }\end{array}$ & $\begin{array}{l}3 \text { art.: } \\
2 \text { Port. } \\
1 \text { Ingl. }\end{array}$ & $\begin{array}{l}2 \text { art.: } \\
1 \text { Port. } \\
1 \text { Ingl. }\end{array}$ & 1 art.: Port. & $\begin{array}{l}5 \text { art.: } \\
2 \text { Port. } \\
3 \text { Ingl. }\end{array}$ \\
\hline Solos e Nutrição de Plantas & $\begin{array}{l}10 \text { art.: } \\
9 \text { Port. } \\
1 \text { Ingl. }\end{array}$ & $\begin{array}{l}10 \text { art.: } \\
\text { Port. }\end{array}$ & $\begin{array}{l}7 \text { art.: } \\
6 \text { Port. } \\
1 \text { Ingl. }\end{array}$ & 4 art. Port. \\
\hline Estatística & 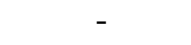 & 1 art.: Port. & - & - \\
\hline $\begin{array}{l}\text { Ciência e Tecnologia de } \\
\text { Alimentos }\end{array}$ & - & - & 1 art.: Port. & 1 art.: Port. \\
\hline Fitopatologia & - & - & 2 art.: Port. & 1 art.:Port. \\
\hline Microbiologia Agrícola & - & - & - & 1 art: Port. \\
\hline Economia Aplicada & - & - & - & 1 art.: Port. \\
\hline Notas & 3 art.: Port. & 7 art.: Port. & $\begin{array}{l}5 \text { art.: } \\
3 \text { Port. } \\
2 \text { Ingl. }\end{array}$ & $\begin{array}{l}3 \text { art. } \\
2 \text { Port. } \\
1 \text { Ingl. }\end{array}$ \\
\hline Revisão & 1 art.: Port. & - & 1 art.: Port. & - \\
\hline TOTAL ARTIGOS & 32 & 31 & 29 & 29 \\
\hline Total idioma Inglês & 03 & 03 & 06 & 07 \\
\hline
\end{tabular}

Fonte: SciELO, 2002

*Texto em Português = PDF em Português $/$ Texto em Inglês $=$ PDF em Inglês Abreviaturas: art. = artigos $/$ Port. $=$ Português $/$ Ingl. = Inglês 
TABELA 31. Classificação dos artigos publicados no Volume 59 da revista "SA" no ano de 2002: levantamento do tipo de formato* disponível e idioma

\begin{tabular}{|c|c|c|c|c|}
\hline Números & $\begin{array}{c}\mathrm{N}^{\circ} 1 \\
\mathrm{jan} / \mathrm{mar}\end{array}$ & $\mathrm{N}^{\circ} 2$ abr/jun & $\begin{array}{c}\mathrm{N}^{0} 3 \\
\text { jul/set }\end{array}$ & $\begin{array}{c}\mathrm{N}^{\circ} 4 \\
\text { out } / \mathrm{dez}\end{array}$ \\
\hline Ciência Animal e Pastagem & 3 art.: & 6 art.: & 4 art.: & 3 art.: \\
\hline & 2 Port. & 5 Port. & 3 Port. & 2 Port. \\
\hline & 1 Ingl. & 1 Ingl. & 1 Ingl. & 1 Ingl. \\
\hline Engenharia Agrícola & - & 1 art.: Port. & - & $\begin{array}{l}3 \text { art.: } \\
1 \text { Port. } \\
1 \text { Ingl. }\end{array}$ \\
\hline Entomologia & - & $\begin{array}{l}4 \text { art.: } \\
3 \text { Port. } \\
1 \text { Ingl. }\end{array}$ & $\begin{array}{l}4 \text { art.: } \\
2 \text { Port. } \\
2 \text { Ingl. }\end{array}$ & $\begin{array}{l}4 \text { art.: } \\
1 \text { Port. } \\
3 \text { Ingl. }\end{array}$ \\
\hline $\begin{array}{l}\text { Fisiologia e Bioquímica das } \\
\text { Plantas }\end{array}$ & $\begin{array}{l}7 \text { art.: } \\
3 \text { Port. } \\
4 \text { Ingl. }\end{array}$ & 1 art.: Port. & - & $\begin{array}{l}2 \text { art.: } \\
1 \text { Port. } \\
1 \text { Ingl. }\end{array}$ \\
\hline Fitotecnia & 5 art.: Port. & $\begin{array}{l}4 \text { art.: } \\
1 \text { Port. } \\
1 \text { Ingl. }\end{array}$ & $\begin{array}{l}4 \text { art.: } \\
3 \text { Port. } \\
1 \text { Ingl }\end{array}$ & $\begin{array}{l}4 \text { art.: } \\
3 \text { Port. } \\
1 \text { Ingl }\end{array}$ \\
\hline $\begin{array}{l}\text { Genética e Melhoramento de } \\
\text { Plantas }\end{array}$ & 1 art.: Port. & $\begin{array}{l}2 \text { art.: } \\
1 \text { Port. } \\
1 \text { Ingl. }\end{array}$ & 1 art.: Ingl. & $\begin{array}{l}4 \text { art.: } \\
1 \text { Port. } \\
3 \text { Ingl. }\end{array}$ \\
\hline Solos e Nutrição de Plantas & $\begin{array}{l}10 \text { art.: } \\
9 \text { Port. } \\
1 \text { Ingl. }\end{array}$ & $\begin{array}{l}5 \text { art.: } \\
2 \text { Port. } \\
3 \text { ingl. }\end{array}$ & $\begin{array}{l}6 \text { art.: } \\
3 \text { Port. } \\
3 \text { ingl. }\end{array}$ & $\begin{array}{l}5 \text { art.: } \\
2 \text { Port. } \\
3 \text { Ingl. }\end{array}$ \\
\hline Estatística & - & 1 art.: Port. & 1 art.: Ingl. & - \\
\hline $\begin{array}{l}\text { Ciência e Tecnologia } \quad \text { de } \\
\text { Alimentos }\end{array}$ & - & - & 1 art.: Port. & - \\
\hline Fitopatologia & - & - & - & $\begin{array}{l}1 \text { art.: } \\
\text { Ingl. }\end{array}$ \\
\hline Microbiologia Agrícola & - & - & - & - \\
\hline Economia Aplicada & - & - & 1 art.: Ingl. & - \\
\hline Agrometeorologia & - & 1 art.: Port. & 1 art.: Ingl. & \\
\hline Notas & $\begin{array}{l}4 \text { art.: } \\
3 \text { Port. }\end{array}$ & $\begin{array}{l}4 \text { art.: } \\
1 \text { Port. }\end{array}$ & $\begin{array}{l}5 \text { art.: } \\
2 \text { Port. }\end{array}$ & $\begin{array}{l}3 \text { art.: } \\
2 \text { Port. }\end{array}$ \\
\hline Revisão & 1 Ingl. & $\begin{array}{l}3 \text { Ingl. } \\
1 \text { art.: Ingl. }\end{array}$ & $\begin{array}{l}3 \text { Ingl. } \\
2 \text { art.: Ingl. }\end{array}$ & $\begin{array}{l}1 \text { Ingl. } \\
1 \text { art.: } \\
\text { Ingl. }\end{array}$ \\
\hline TOTAL ARTIGOS & 30 & 30 & 30 & 30 \\
\hline Total idioma Inglês & 07 & 12 & 15 & 16 \\
\hline
\end{tabular}

Fonte: SciELO, 2002

*Texto em Português $=$ PDF em Português $/$ Texto em Inglês $=$ PDF em Inglês

Abreviaturas: art. = artigos / Port. = Português / Ingl. = Inglês

Nas Tabelas 30 e 31 os números indicam que houve um aumento de 31 artigos da revista "SA" escritos em inglês de 2001 para 2002. Dos 121 artigos do 
ano de 2001, 19 (15,7\%) estavam em inglês, e dos 120 artigos de 2002, 50 (41,6\%) também estavam em inglês, ou seja, quase a metade.

Na opinião do ex-editor-chefe da revista "SA”, Klaus Reichardt (1998, lv.) falta incluir a revista no "Current Contents” para sua solidificação internacional, enfatizando a importância de se publicar cada vez mais artigos em língua inglesa para que os mesmos sejam citados com mais freqüência. Dos 369 artigos publicados no período de 1992 a 1997, 16,5\% estão em língua estrangeira, o que para o autor é muito pouco.

O “Current Contents Conect - CCC” é uma base de dados gerenciada pelo Institute for Scientific Information/Estados Unidos, sendo atualizada semanalmente. Tem abrangência temática com sumários de periódicos internacionais e livros recém-publicados de Agricultura, Biologia e Ciências do Meio Ambiente, Ciências da Vida, Ciências Sociais do Comportamento, Engenharia, Informática e Tecnologia (www.cpac.embrapa.br/biblioteca, 13 Fev. 2002).

Nos quatro fascículos de 2002, as seções da revista "SA": Ciências Animal e Pastagem, Solos e Nutrição de Plantas e Notas publicaram artigos em inglês; em Entomologia, Fitotecnia, Genética e Melhoramento de Plantas e na Revisão, exceto o $n^{\circ} 1$, todos os outros três fascículos também publicaram um ou mais artigos em inglês.

Cabe ressaltar que as seções da mesma revista: Solos e Nutrição de Plantas e Ciência Animal e Pastagem contêm maior número de artigos, as outras seções como Fitotecnia, Fisiologia e Bioquímica de Plantas, Genética e Melhoramento de Plantas e Entomologia também apresentam número de artigos significantes. 


\section{A REVISTA SCIENTIA FORESTALIS NA BASE DE DADOS CABI INTERNACIONAL}

\section{Levantamento das bases onde a revista está indexada}

A revista ganha importância no cenário nacional e internacional com a indexação, em 1997, de todos os seus artigos nos Abstracts da CABI Internacional, que posteriormente gerou o Tree-Cd, abrangendo os principais abstracts florestais.

A CABI Publishing possui um extensivo programa de periódicos e é considerada líder internacional como editor de ciências aplicadas da vida, incluindo ciência animal, nutrição, gestão integrada de culturas, ciências das plantas e florestas (http://www.lusodoc.pt, 13 Fev. 2004).

Na CABI estão indexados apenas os resumos dos artigos. No abstract estão descritos: English Title, Author, Author Affiliation, Source, Abstract, Descriptor, Organism Descriptors, Geographical Location e Up-posted Descriptors.

Conforme consulta feita às bibliotecárias da ESALQ, fomos informados de que a CABI não apresenta dados (número de revistas citantes, citadas etc) como a SciELO, que limitou nossa análise, uma vez que a referida base apenas disponibiliza os abstracts. 